LUCIANA DE MELO PEIXOTO

REQUISITOS E CRITÉRIOS DE DESEMPENHO PARA SISTEMA DE ÁGUA NÃO POTÁVEL DE EDIFÍCIOS RESIDENCIAIS 


\title{
REQUISITOS E CRITÉRIOS DE DESEMPENHO PARA SISTEMA DE ÁGUA NÃO POTÁVEL DE EDIFÍCIOS RESIDENCIAIS
}

\author{
Dissertação apresentada à Escola \\ Politécnica da Universidade de São \\ Paulo para obtenção do título de \\ mestre em Engenharia. \\ Área de concentração: \\ Engenharia de Construção Civil e \\ Urbana \\ Orientador: \\ Prof. Dr. Orestes Marraccini \\ Gonçalves
}


Dissertação apresentada à Escola Politécnica da Universidade de São Paulo para obtenção do título de mestre em Engenharia.

Área de concentração:

Engenharia de Construção Civil e Urbana

Orientador:

Prof. Dr. Orestes Marraccini

Gonçalves 
Este exemplar foi revisado e alterado em relação à versão original, sob responsabilidade única do autor e com a anuência de seu orientador.

São Paulo, de janeiro de 2009.

Assinatura do autor

Assinatura do orientador

FICHA CATALOGRÁFICA

Peixoto, Luciana de Melo

Requisitos e critérios de desempenho para sistema de água não potável de edifícios residenciais I L.M. Peixoto. -- ed.rev. -São Paulo, 2009.

p.

Dissertação (Mestrado) - Escola Politécnica da Universidade de São Paulo. Departamento de Engenharia de Construção Civil.

1.Água não potável 2.Água (Conservação) 3.Reuso da água I.Universidade de São Paulo. Escola Politécnica. Departamento de Engenharia de Construção Civil II.t. 
Dedico este trabalho ao alicerce da minha vida, meus queridos pais. 


\section{AGRADECIMENTOS}

Agradeço a todos que compartilharam para o desenvolvimento deste trabalho.

Primeiramente a Deus, por me proteger, iluminar e fortalecer em todos os momentos da minha vida. Sem ele nada acontece!

Ao Professor Orestes pelo apoio durante todos esses anos e por toda sabedoria transmitida, contribuindo para a minha vida profissional.

A Professora Lúcia Helena pelas conversas de extrema valia que contribuíram imensamente para realização deste trabalho.

Ao Professor Ivanildo Hespanhol e José Carlos Mierzwa pelas contribuições sobre o tema.

A minha família que compartilhou todos os momentos comigo, acreditando em mim e me apoiando sempre, cada um de uma maneira especial. Com certeza o amor é fundamental neste momento da vida.

Aos GRANDES amigos que fiz durante este período. Muito Obrigada!

A Giorgio Vanossi por confiar no meu trabalho e compartilhar as informações práticas que foram imprescindíveis para a elaboração deste trabalho.

Aos meus colegas do escritório que entenderam a minha ausência durante a realização deste trabalho. 


\section{RESUMO}

A utilização de fonte alternativa de água em edifícios residenciais vem sendo praticada de forma mais constante nos últimos anos, com objetivo de reduzir a demanda de água potável. No entanto, a utilização de água não potável exige critérios que devem ser respeitados, para preservar a saúde dos usuários, tendo em vista a possibilidade de contaminação da água potável fornecida pela concessionária. Assim, este trabalho tem como objetivo apresentar requisitos e critérios de desempenho que devem ser aplicados nas fases de projeto, execução e manutenção do sistema predial de água não potável. Para apoiar os projetistas, executores e gestores na tomada de decisão das diferentes etapas do processo foi também desenvolvida e aplicada uma ferramenta para análise de modo e efeito de falha (FMEA) dos requisitos desenvolvidos para o sistema de água não potável. Os resultados obtidos com a aplicação da ferramenta em edifício comprovaram a sua aplicabilidade e eficiência no sistema predial de água não potável.

Palavras-Chave: Água não-potável. Água (Conservação). Reúso da Água. 


\begin{abstract}
The use of alternative source of water in residential buildings has been practiced in more constant in recent years aiming to reduce the demand for potable water (drinking water). However, the use of non-potable water requires criteria that must be respected to preserve the health of users, with a view to possible contamination of potable water supplied by the concessionaire. Therefore, this paper aims to present requirements and performance criteria, which must be implemented in phases of design, implementation and maintenance of the nonpotable water system in building. To assist the designers, performers and managers in decision-making of the different stages of the process was also developed and implemented analyze with the tool failure mode effect analysis (FMEA) for the requirements developed for the non-potable water system in building. The results achieved by the tool showed its applicability and efficiency in non-potable water system in building.
\end{abstract}




\section{LISTA DE FIGURAS}

Figura 1.1 - Estrutura da pesquisa. 8

Figura 2.1 - Representação do enfoque sistêmico no sistema de fonte alternativa de água.................................10

Figura 2.2 - Fluxograma das etapas do sistema de coleta de esgoto sanitário em edifício que possui a fonte alternativa de água oriunda dos lavatórios e chuveiros. .................................................................... 11

Figura 2.3 - Fluxograma representando o sistema de distribuição de água em edifício que possui a fonte alternativa de água.

Figura 2.4 - Composição do sistema predial de água não potável ........................................................... 13

Figura 2.5- Planta baixa e corte de banheiro residencial, apresentando componentes do SPAC. ....................... 15

Figura 2.6 - Esquema vertical do SPAC do edifício residencial.................................................................. 16

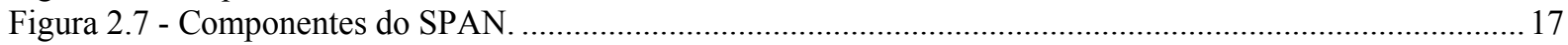

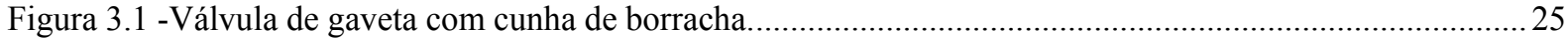

Figura 3.2-Válvula três vias controla o fluxo em duas direções....................................................................26

Figura 3.3 - Detalhe do sistema predial instalado no prédio contaminado. .................................................... 30

Figura 3.4 Separação horizontal e vertical entre as tubulações dos sistemas prediais de água adaptado EPA

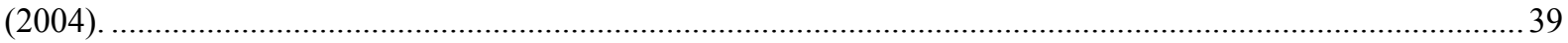

Figura 3.5 - Alternativa da previsão da fonte de água potável, a partir do alimentador predial. ........................45

Figura 3.6- Modelo de válvula de retenção dupla com diferencial de pressão (WATTS, 2008)........................46

Figura 4.1 - Fluxograma das etapas que compõe a aplicação da FMEA. ......................................................53

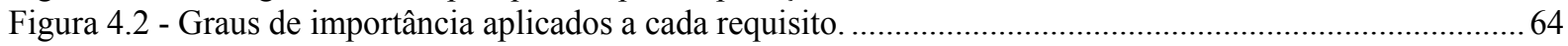

Figura 4.3 - Visualização dos pontos de controle do sistema predial de água não potável. ................................68

Figura 5.1 - Fluxo de informação entre os membros responsáveis pela implantação do sistema de água não

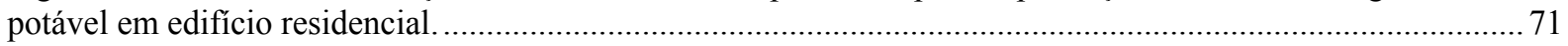

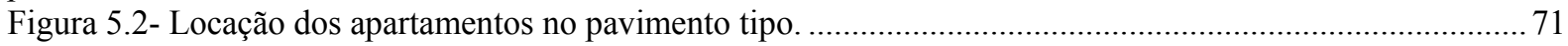

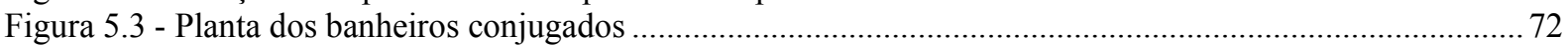

Figura 5.4 -Detalhe do sistema predial de esgoto sanitário dos banheiros conjugados. ..................................... 75

Figura 5.5 - Esquema vertical do SPAC do banheiro conjugado............................................................ 75

Figura 5.6 - Válvulas de gaveta com a função de bloquear ou permitir a entrada do efluente na estação de

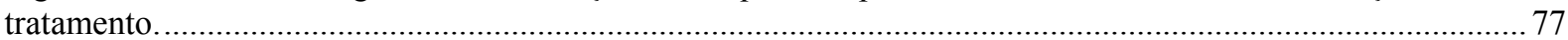

Figura 5.7- Válvula para limpeza, instalada na saída do reservatório de coleta de águas cinzas. ........................78

Figura 5.8 - Válvula solenóide para descarte do lodo da estação de tratamento ............................................79

Figura 5.9 - Extravasor instalado no reservatório de coleta de água cinza. .................................................. 79

Figura 5.10 - Componentes de inspeção na tubulação do desvio do tubo de queda de água cinza.....................80

Figura 5.11 - Sistema de tratamento físico-químico implantado no empreendimento. ...................................... 84

Figura 5.12 - Componentes da ETAC: (a)Reservatório de armazenamento de produtos químicos, (b)módulo de tratamento e (c) vista superior do módulo de tratamento. ...................................................................... 86

Figura 5.13 - Central Lógica Programável (CLP) - sistema de informação responsável pela automatização da

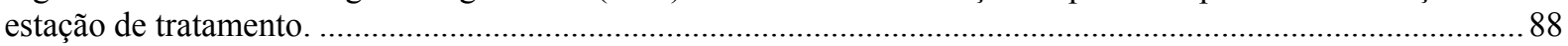

Figura 5.14 - Isométrica dos reservatórios superiores de água potável e não potável (representado pela cor roxa).

Figura 5.15 - Isométrica dos banheiros conjugados

Figura 5.16 - Identificação nas tubulações adotada do empreendimento. .......................................................93

Figura 5.17 - Aparência da água não potável pigmentada com azul de metileno..........................................94

Figura 5.18- Aparência da água não potável pigmentada com a cor azul e laranja, conforme recomendação do

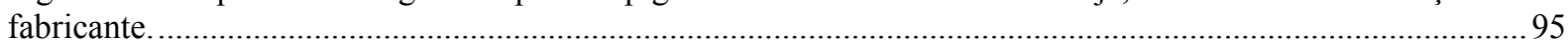

Figura 5.19 - A previsão da alimentação de água potável no reservatório de água não potável.........................97

Figura 5.20 - Reservatório de água não potável e ramais de alimentação de água potável: (a) detalhe e (b) foto.98 


\section{LISTA DE TABELAS}

Tabela 1.1 - Atividade do reúso considerada nos métodos de avaliação (KALBUSCH, 2006)..........................4

Tabela 3.1 - Requisitos para SPAC e respectivos critérios........................................................................22

Tabela 3.2 - Requisitos de desempenho e diretrizes internacionais para o SPAN.........................................36

Tabela 3.3 - Monitoração da qualidade do efluente tratado. FONTE: EPA (2005)..........................................3

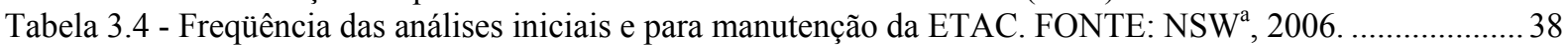

Tabela 3.5 - Dimensões das letras de acordo com o diâmetro da tubulação. FONTE: WHO (2007) .................. 41

Tabela 4.1- Modelo de tabela para aplicação da FMEA - Fase investigação.................................................51

Tabela 4.2 - Etapas consideradas na fase controle da ferramenta FMEA........................................................5 51

Tabela 4.3 - Valor do item severidade, ocorrência e detecção da falha...........................................................5 52

Tabela 4.4 - Causa e efeito de falha para o requisito qualidade da água. .......................................................5

Tabela 4.5 - Grau de risco, estabelecido pela severidade, ocorrência e detecção de cada falha, e índice de falha parcial e total do requisito qualidade da água e saúde.............................................................................55

Tabela 4.6 - Respectivas ações corretivas e de controle para manter o requisito qualidade da água....................57

Tabela 4.7 - Causa e efeito de falha para o requisito quantidade...............................................................5 58

Tabela 4.8 - Grau de risco estabelecido pela severidade, ocorrência e detecção de cada falha e índice de falha

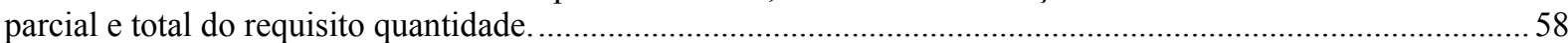

Tabela 4.9 - As ações corretivas e de controle para manter o requisito quantidade da água ...............................59

Tabela 4.10 - Causa e efeito de falha para o requisito conforto. ................................................................59

Tabela 4.11 - Grau de risco, estabelecido pela severidade, ocorrência e detecção de cada falha, e índice de falha

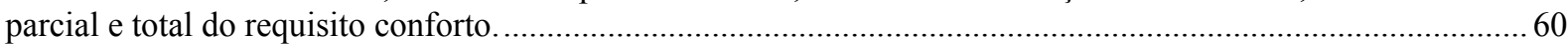

Tabela 4.12 - Respectivas ações corretivas e de controle para manter o requisito conforto................................6 61

Tabela 4.13 - Tabulação dos NPR de cada requisito apresentado..............................................................62

Tabela 4.14 - Classificação dos graus de importância considerado nas ações essenciais..................................65

Tabela 4.15 - Valores das ações essenciais nas fases projeto (P), execução (E) e manutenção (M) do requisito

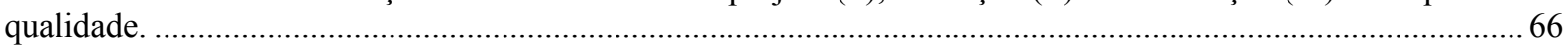

Tabela 5.1 - Dimensões dos ramais do SPES, utilizando o método das UHC (NBR 8160, 1999) ......................81

Tabela 5.2 - Diâmetros das tubulações dos SPAC, conforme método UHC e Hidráulico..................................8 82

Tabela 5.3 - Resumo dos requisitos do SPAC, atendidos nos empreendimentos............................................ 83

Tabela 5.4 - Comparação dos valores de consumo de água cinza obtidos do CIRRA e da projetista da ETAC...85

Tabela 5.5 Resumo dos requisitos atendidos da ETAC ............................................................................ 89

Tabela 5.6 - Resumo do atendimento dos requisitos e critérios do sistema predial de água não potável.............99

Tabela 5.7 - Verificação das ações essenciais consideradas no edifício para o requisito qualidade.................... 101

Tabela 5.8 - Falhas 01, 02, 03 e 04 com seus respectivos nível prioritário de risco (NPR). ............................ 102

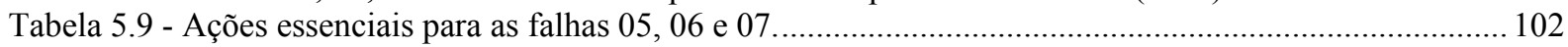

Tabela 5.10 - Falhas 05, 06, e 07 com seus respectivos nível prioritário de risco (NPR).............................. 103

Tabela 5.11 - Valores das ações essenciais do requisito qualidade para as fases projeto (P), execução (E) e

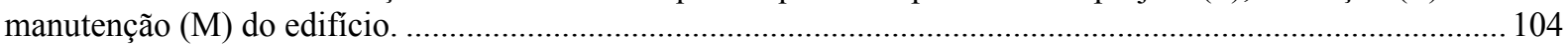

Tabela 5.12 - Ações essenciais para as falhas do requisito quantidade. .................................................... 105

Tabela 5.13 - As falhas com seus respectivos nível prioritário de risco (NPR) para o requisito quantidade...... 106

Tabela 5.14 - Verificação das ações essenciais consideradas no edifício para o requisito conforto.................... 106

Tabela 5.15 - As falhas com seus respectivos níveis prioritários de risco (NPR) para o requisito conforto....... 107 


\section{LISTA DE SIGLAS E ABREVIATURAS}

ABNT

APCC

APP

BSRIA

CASBEE

CBCS

CIB

CIRRA

CLP

DBO

EPA

ETAC

FMEA

GI

HACCP

HAZOP

HQE

IF

LEED

NBR

NPR

NSW

PBQPH
Associação Brasileira de Normas Técnicas

Análise de perigo e pontos críticos controláveis

Análise Preliminar de Risco e Perigo

The Building Services Research and Information Association

Comprehensive Assessment System for Building Environmental Efficiency

Comitê Brasileiro de Construção Sustentável

International Council of Research and Innovation in Building and Construction

Centro Internacional de Referência em Reúso de Água

Comando Lógico Programável

Demanda Bioquímica de Oxigênio

Environmental Protect Agency

Estação de Tratamento das Águas Cinzas

Análise de Modo de Falha e Efeito

Grau de Importância

Hazard Analysis Critical Control Point

Análise de Perigo e Operabilidade

Haute Qualité Environnementale

Índice de Fase

Leadership in Energy \& Environmental Design

Norma Brasileira Registrada

Nível Prioritário de Risco

New South Wales

Programa Brasileiro da Qualidade e Produtividade do habitat 
PMI

PNCDA

RD

RE

SBTOOL

SPAC

SPAN

SPAP

UHC

WRAS
Project Management Institute

Programa Nacional de Combate ao Desperdício da Água

Ramal de descarga

Ramal de esgoto

Sustainable Building Assessment Tool

Sistema Predial de Água Cinza

Sistema Predial de Água Não Potável

Sistema Predial de Água Potável

Unidade Hunter de Contribuição

Water regulations Advisory Scheme 


\section{SUMÁRIO}

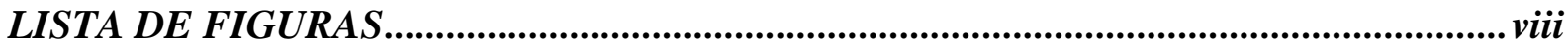

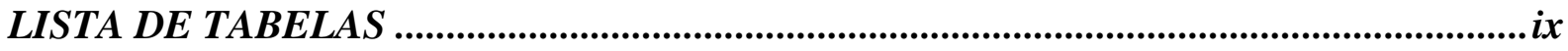

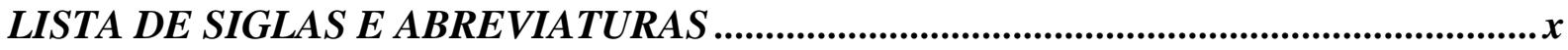

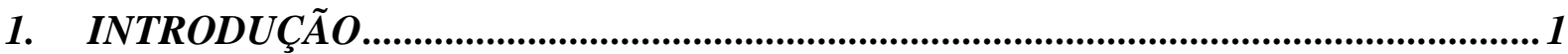

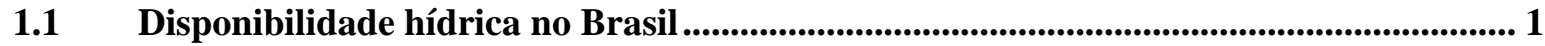

$1.2 \quad$ A sustentabilidade nos sistemas prediais ................................................................................ 3

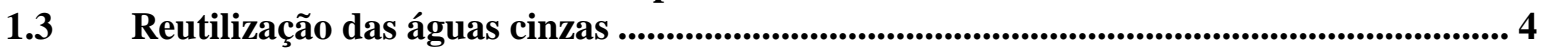

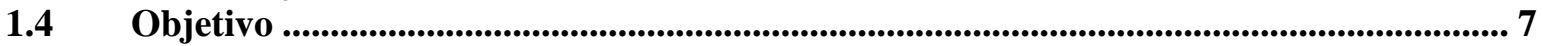

1.5 Metodologia da pesquisa ...................................................................................................... 7

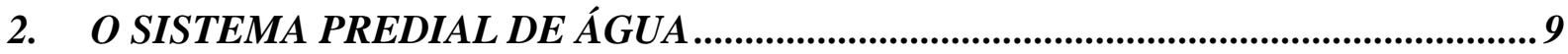

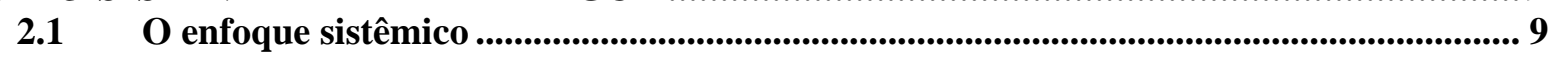

2.2 Sistema predial de água não potável: coleta de água cinza e distribuição de água não

potável $\quad 10$

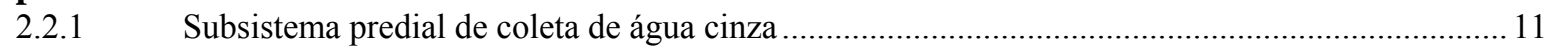

2.2.2 Subsistema de distribuição de água não potável..................................................................... 11

2.3 Função dos sistemas prediais de água não potável ............................................................. 12

2.4 Componentes do sistema predial de água não potável ........................................................ 14

2.5 Impactos da nova morfologia no edifício ............................................................................... 17

3. REQUISITOS DE DESEMPENHO DO SISTEMA PREDIAL DE ÁGUA NÃO

POTÁVEL .....................................................................................................................19

3.1 Abordagem de desempenho - Conceituação ................................................................... 19

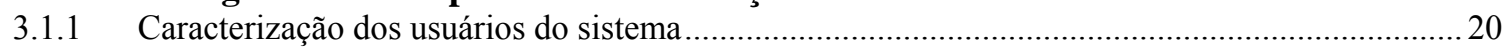

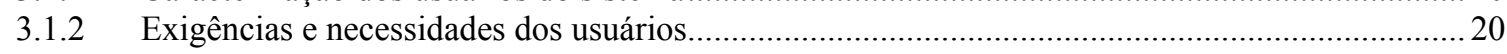

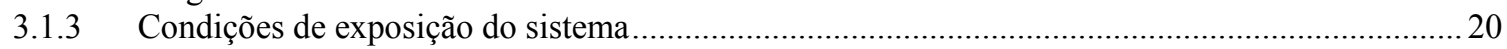

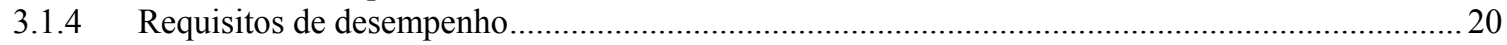

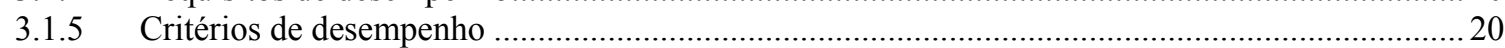

3.2 Requisitos de desempenho para o subsistema predial de coleta de água cinza............ 21

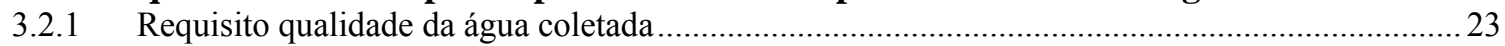

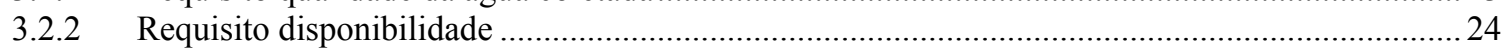

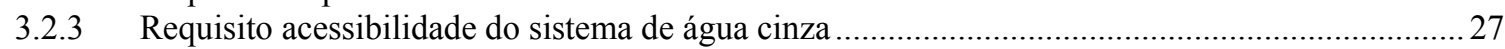

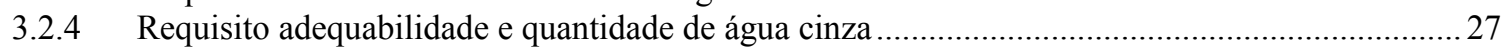

3.2.5 Requisito odores e ataque biológico do sistema predial de coleta de água cinza ............................2 28

3.2.6 Requisito quantidade para estação de tratamento de água cinza....................................................... 31

3.2.7 Requisito ataque biológico para a estação de tratamento de água cinza ............................................33

3.2.8 Requisito preservação da natureza para estação de tratamento de água cinza ......................................34

3.2.9 Requisito resistência mecânica para estação de tratamento de água cinza .........................................34

3.2.10 Requisito operação para a estação de tratamento de água cinza.........................................................35

3.3 Requisitos de desempenho do sistema predial de água não potável ................................ 35

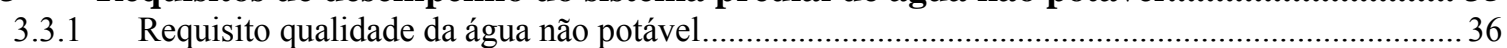

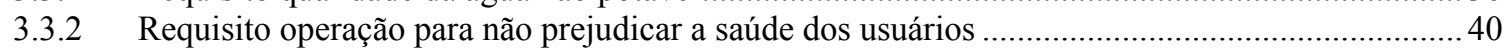

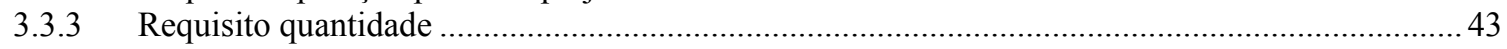

4. O MÉTODO FMEA E SUA APLICACÃO NO SISTEMA PREDIAL DE ÁGUA NÃO

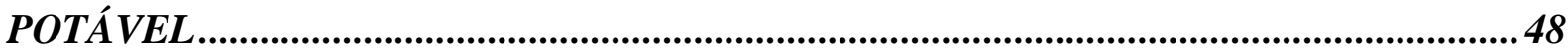

4.1 Métodos de análise de riscos ............................................................................................... 48

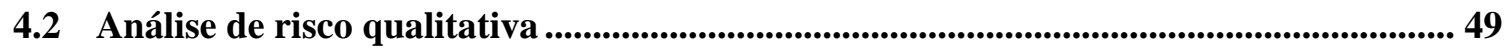

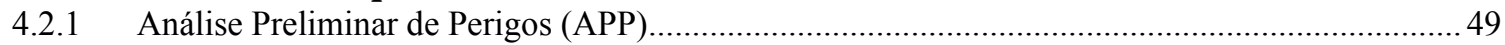

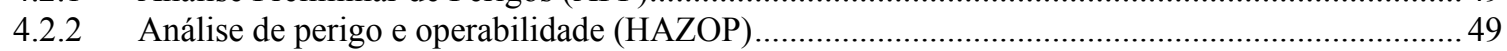




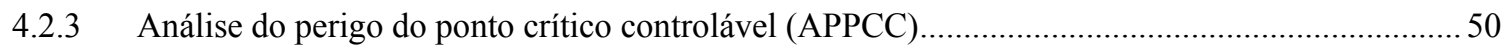

4.2.4 Análise de modo de falha e efeito (FMEA) ...........................................................................5 50

4.3 Aplicação da FMEA no sistema predial de água não potável.................................... 52

4.3.1 Análise de modo de falha e efeito para o requisito qualidade da água ........................................53

4.3.2 Análise do modo e efeito de falha para o requisito Quantidade .................................................57

4.3.3 Análise do modo e efeito de falha para o requisito conforto .................................................5

4.3.4 Tabulação do nível prioritário de risco (NPR) de cada requisito .............................................. 61

4.4 Hierarquização das atividades essenciais do requisito QUALIDADE ......................... 64

5. APLICABILIDADE DOS REQUISITOS PROPOSTOS EM EDIFÍCIO

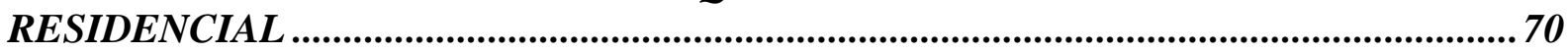

5.1 Características do Empreendimento ........................................................................ 70

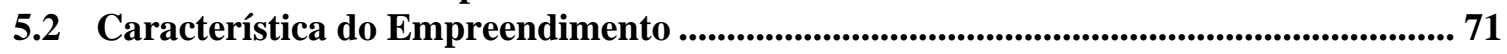

5.3 Característica do sistema predial de água não potável ............................................. 72

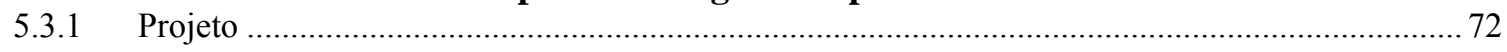

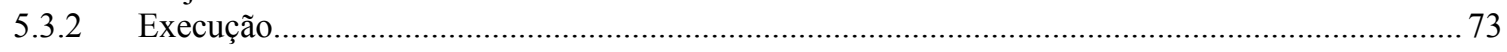

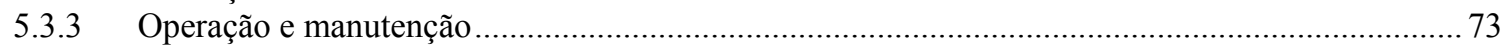

$5.4 \mathrm{O}$ Subsistema predial de coleta de águas cinzas.................................................... 74

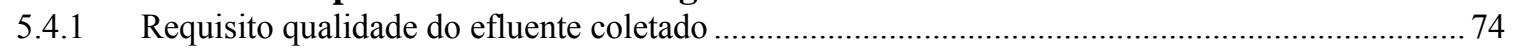

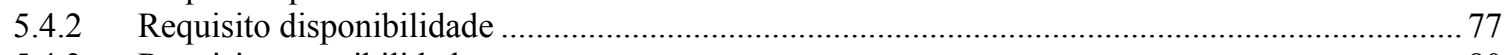

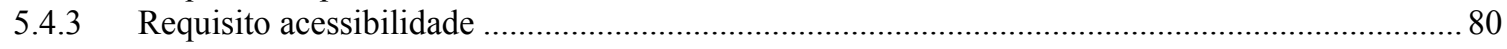

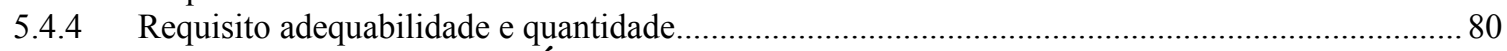

5.5 Estação de Tratamento de Água Cinza - ETAC ................................................... 84

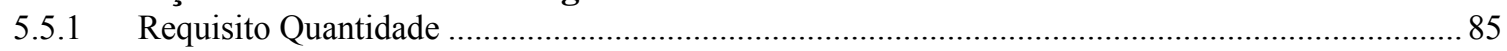

5.5.2 Requisito Qualidade, Durabilidade, Preservação da Natureza e Resistência Mecânica ................86

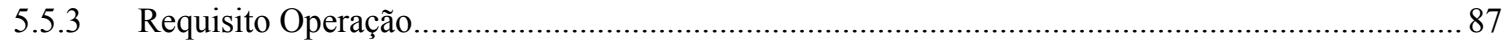

5.6 Sistema predial de água não potável............................................................... 89

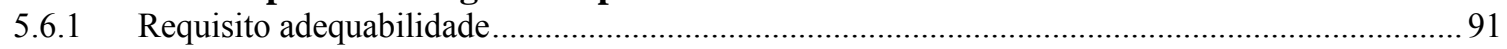

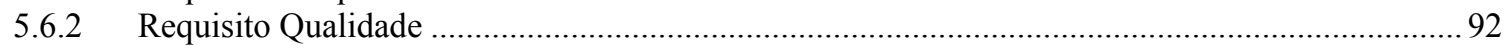

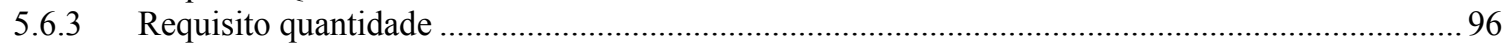

5.7 Análise do Modo e Efeito de Falha para esse projeto ................................................ 100

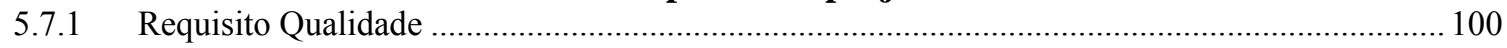

5.7.2 Análise das ações essenciais do requisito qualidade no edifício................................................ 103

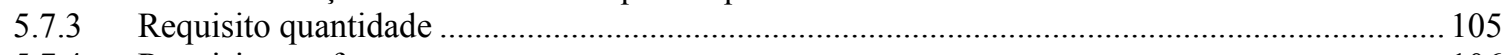

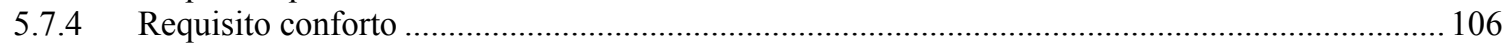

6. CONCLUSÕES......................................................................................................108

REFERÊNCIAS BIBLIOGRÁFICAS ...........................................................................111

ANEXO 01 - DIMENSIONAMENTO HIDRÁULICO..........................................................116

ANEXO 03 - DIMENSIONAMENTO DO SISTEMA DE DISTRIBUIÇÃO......................128 


\section{INTRODUÇÃO}

\subsection{Disponibilidade hídrica no Brasil}

O Brasil é um país privilegiado no que se refere à quantidade de água, pois possui cerca de $50 \%$ de toda água existente na América do Sul e 11\% dos recursos mundiais, totalizando $168,87 \mathrm{~m}^{3} / \mathrm{s}$ (HESPANHOL; TUCCI, 2006), ocupando o primeiro lugar na lista dos países que possui maior disponibilidade de água no mundo.

O volume de água disponível no país não reflete a possibilidade de abastecimento para os habitantes. A maior parte da reserva hídrica brasileira encontra-se na região norte do país, a qual possui o menor número de habitantes, enquanto que a região sudeste, a mais populosa, possui uma das menores disponibilidade hídrica por habitante do país (MIERZWA, 2002).

O crescimento populacional nas grandes cidades aumentou após a Segunda Guerra Mundial, e a disponibilidade de água nessas regiões é considerada constante ou menor, devido às condições climáticas e poluição dos mananciais. As regiões nordeste e sudeste são as maiores prejudicadas, sendo a primeira pela falta de disponibilidade hídrica como fator principal e a segunda devido à densidade populacional.

O cenário crítico apresentado demonstra a necessidade urgente de uma maior preocupação com o uso racional da água, pautado na integração dos sistemas prediais e de uma maior racionalização dos processos construtivos (GONÇALVES, 2000). Além disso, o referido autor aponta a importância de planejar e implantar processos que envolvam um complexo de interações, considerações políticas, legislativas e procedimentos administrativos, operacionais e de manutenção.

O governo brasileiro, diante da condição nacional de disponibilidade de água, implantou em 1997, o Programa Nacional de Combate ao Desperdício da Água (PNCDA), que tem por objetivo geral promover o uso racional da água de abastecimento público nas cidades brasileiras, em benefício da saúde pública, do saneamento ambiental e da eficiência dos serviços (PNCDA, 2006). 
Oliveira (1999) afirma que a gestão da água almejada como medida de conservação deste recurso natural pode ser implantada em nível macro, meso e micro, sendo diferenciadas pelo sistema a que pertencem, que são:

- macro - sistemas hidrográficos;

- meso - sistema público de abastecimento de água e coleta de esgoto e;

- micro - sistemas prediais.

A gestão da água aplicada no sistema predial é obtida através da redução do volume de água utilizado pelo usuário; redução do desperdício de água no edifício, causado pelas perdas; e pela utilização de fontes alternativas de água.

Em linhas gerais, o volume de água consumido na habitação é reduzido pela implantação de dispositivos economizadores. Esses dispositivos atuam na redução da vazão como também na duração da utilização do equipamento. A redução do desperdício, atividade também considerada na gestão da água, ocorre com a detecção de vazamentos e com a educação da população. E como fonte alternativa é considerada a captação direta de mananciais, água subterrânea, água pluvial e reúso de efluentes (SAUTCHUK, 2004).

Nesse mesmo contexto Gonçalves (2003) afirma que o programa de conservação da água consiste na otimização da demanda somada ao uso de ofertas alternativas de água, o que resulta na utilização de água "menos nobre" para fins "menos nobre".

A utilização de fonte alternativa de água no edifício como medida de conservação deve ser aplicada com responsabilidades semelhantes às das concessionárias. A concessionária é responsável pela água entregue aos usuários, que possui grau de potabilidade para fins potáveis, conforme estabelecido na Portaria do Ministério da Saúde № 518 (2004). A implantação de fonte alternativa no empreendimento transfere a responsabilidade para o gestor do local, considerado um "produtor" de água que, semelhante à concessionária, deve respeitar os padrões mínimos de qualidade, os quais variam de acordo com a utilização final dessa água.

Segundo Sautchuk (2004), além de produzir água com os padrões de qualidade para uso específico, o produtor dessa água deve: 
- atender a legislação de outorga para o uso;

- atender às normas vigentes;

- implantar sistema de gestão e monitorar continuamente a qualidade e a quantidade dessa água;

- capacitar e conscientizar os usuários envolvidos.

\subsection{A sustentabilidade nos sistemas prediais}

A gestão do uso da água como estratégia de preservação deste recurso vem ao encontro do desenvolvimento sustentável, uma vez que pretende garantir disponibilidade de água para gerações futuras e sem este recurso, não há possibilidade de vida na terra (KALBUSCH, 2006).

O desenvolvimento sustentável na construção civil é encorajado a partir da implantação de métodos de avaliação relacionados às atividades sustentáveis. Como exemplos de métodos existentes podem ser citados: Haute Qualité Environnementale - NF HQE, Comprehensive Assessment System for Building Environmental Efficiency -CASBEE, Leadership in Energy \& Environmental Design - LEED e Sustainable Building Assessment Tool - SBTOOL. A certificação do empreendimento é obtida a partir do resultado da avaliação por um destes métodos. A avaliação realizada em cada categoria ou subsistema, a partir do atendimento dos parâmetros pré-estabelecidos.

Na categoria água são exigidos como indicadores a implantação de medidas de conservação, tais como a utilização de equipamentos economizadores, medição individual de água, utilização de fonte alternativa, entre outras.

A Tabela 1.1 apresenta as atividades necessárias, relacionadas à utilização de fonte alternativa de água segundo os métodos de avaliação: SBtool, LEED, HQE e CASBEE (KALBUSCH, 2006). 
Tabela 1.1 - Atividade do reúso considerada nos métodos de avaliação (KALBUSCH, 2006).

\begin{tabular}{|c|l|}
\hline \hline $\begin{array}{c}\text { Sistema de } \\
\text { avaliação }\end{array}$ & \multicolumn{1}{c|}{ Parâmetro avaliado referente ao reúso de efluente } \\
\hline \hline SBtool & $\begin{array}{l}\text { Reúso de água no local para diminuição do volume anual de águas cinzas encaminhado ao } \\
\text { sistema de esgoto. }\end{array}$ \\
\hline LEED & $\begin{array}{l}\text { Limitação ou eliminação do uso de água potável para irrigação paisagística através do reúso } \\
\text { da água. }\end{array}$ \\
\hline HQE & $\begin{array}{l}\text { Redução do consumo de água potável através da utilização de água não potável para usos } \\
\text { que não requerem água com tal qualidade. }\end{array}$ \\
\hline CASBEE & $\begin{array}{l}\text { Redução da carga na infra-estrutura local de tratamento de esgoto, através do sistema de } \\
\text { reúso. }\end{array}$ \\
\cline { 2 - 3 } & $\begin{array}{l}\text { Contenção da formação de ilhas de calor com a previsão de espaços verdes e de um corpo } \\
\text { d'água no terreno. Uma das recomendaçóes é o emprego de irrigação de áreas verdes } \\
\text { utilizando água pluvial ou esgoto (reúso de água). }\end{array}$ \\
\hline
\end{tabular}

Conforme apresentado na Tabela 1.1, a utilização de fonte alternativa de água é um dos parâmetros avaliados que contribui para a certificação de edifício sustentável. Esse prérequisito é considerado preocupante devido à inexistência dos seguintes fatores: profissionais capacitados para projetar, executar e operar o sistema; órgãos públicos para aprovar e fiscalizar a implantação desses sistemas; legislação adequada; usuários cientes da tecnologia entre outros fatores que podem contribuir para o comprometimento da saúde dos usuários.

\subsection{Reutilização das águas cinzas}

O reúso da água consiste no aproveitamento de água previamente utilizada, uma ou mais vezes, em alguma atividade humana, para suprir as necessidades de outros usos benéficos, inclusive o original (LAVRADOR, 1987).

Este trabalho considera água não potável a que possui padrão de qualidade de acordo com a finalidade do seu uso, sendo esse inferior ao da água potável. Segundo a Portaria do Ministério da Saúde № 518 (2004) “a água potável é aquela própria para o consumo humano cujos parâmetros microbiológicos, físicos, químicos e radioativos atendam ao padrão de potabilidade e que não ofereça riscos à saúde".

Segundo a NBR 5626 (ABNT, 1998) “(...) a água não potável pode ser utilizada para a limpeza das bacias sanitárias e mictórios, para combate a incêndios e para outros usos onde o requisito de potabilidade não se faça necessário".

O esgoto doméstico é composto pelas águas cinzas e negras. As águas negras correspondem aos efluentes produzidos nas bacias sanitárias e caracterizam-se pela grande presença de 
coliformes termotolerantes na sua composição. As águas cinzas são os efluentes produzidos com a utilização dos demais equipamentos existentes na habitação, lavatório, chuveiro, tanque, máquina de lavar e pia da cozinha.

A água cinza oriunda do lavatório e chuveiro pode ser considerada menos poluída dentre as originadas em todos os equipamentos, entretanto, deve-se considerar o teor de poluição. A qualidade dessa água é influenciada pelos hábitos de cada usuário com características particulares de cada um, o que não é possível generalizar uma composição física, química e biológica.

Segundo Henze \& Ledin (2001) as águas cinzas podem ser divididas em claras e escuras. As escuras correspondem aos efluentes produzidos no banho, cozinha e lavatório e as claras são as originadas no banho, lavatório e máquina de lavar roupa.

A poluição dessa água ainda pode ser maior, caso existam crianças ou idosos na habitação. A presença de crianças na habitação pode aumentar o número de coliformes termotolerantes presentes no efluente, devido às atividades de lavagem de fraldas, como também na limpeza da criança no lavatório ou no chuveiro (NOLDE, 1999).

A presença de coliformes termotolerantes pode influenciar na contaminação da água cinza, e conseqüentemente, proporcionar maior risco à saúde dos usuários. Por isso, a utilização dessa água nas bacias sanitárias só é possível com a implantação do sistema de tratamento adequado, capaz de tornar a água em condições seguras de uso.

A bacia sanitária, quando comparada aos demais equipamentos sanitários, é considerada a que propicia menor contato da água com o usuário. No entanto, ele pode existir durante as atividades de manutenção da caixa de descarga, através do manuseio dos acessórios, existentes no interior da caixa e também, no assento molhado, caso ocorra o respingo da água durante o acionamento da descarga.

A escolha do efluente a ser utilizado é influenciada por dois aspectos: volume produzido, que deve ser compatível com o necessário para atender a demanda nas descargas das bacias sanitárias e a qualidade desse efluente, já que influencia diretamente na especificação do sistema de tratamento. 
Segundo Metcalf \& Eddy (1991) a segurança do sistema de reúso pode ser comprometida devido a dois fatores: a ocorrência de falha do sistema de tratamento e à qualidade do efluente que vai ser tratado.

A ocorrência de uma falha não detectada na estação de tratamento não impede a contínua operação do sistema, distribuindo água não potável com qualidade inferior a desejada, conseqüentemente, os usuários correm o risco de serem contaminados. A coleta de efluentes com teor de qualidade diferente da prevista compromete o desempenho da estação de tratamento, conseqüentemente, a água, embora tratada, poderá possuir características indesejáveis para o reúso, situação que se pode comprometer a saúde do usuário.

Além das formas de contaminação apresentadas por Metcalf \& Eddy (1991), o usuário também pode ser contaminado pelo consumo de água não potável em equipamentos inadequados, devido à interligação inadequada entre as tubulações, denominada conexão cruzada. Um exemplo é a água que foi tratada para ser distribuída nas descargas das bacias sanitárias, pode ser conduzida para o chuveiro devido a uma conexão cruzada.

$\mathrm{Na}$ cidade de Leidsche Rijn, Holanda houve um acontecimento de conexão cruzada entre os sistemas de distribuição de água. Segundo Schee (2004) essa conexão cruzada ocorreu durante a execução das tubulações de água potável e não potável, que conduziam água para 3000 casas, por meio de conexões provisórias instaladas nas tubulações. $\mathrm{O}$ erro de execução proporcionou a contaminação de 1000 casas.

A segurança relacionada à saúde dos usuários é um dos requisitos de desempenho de um sistema de água não potável. Diante da sua importância e necessidade, este trabalho apresenta os requisitos e critérios que devem ser considerados nas fases de projeto, execução e operação do sistema predial de água, quando inserida uma fonte alternativa de água.

Ressalta-se que não é objeto deste estudo a estação de tratamento de água cinza. Considera-se apenas que ela é capaz de tornar as águas cinzas claras em condições físicas, químicas e biológicas para uso nas bacias sanitárias, sem prejudicar a saúde dos usuários. 


\subsection{Objetivo}

O objetivo geral desta pesquisa é mostrar a importância da aplicação criteriosa de sistemas de água não potável, tendo em vista a preservação da saúde dos usuários em edifícios residenciais.

- elaborar requisitos e critérios de desempenho: de projeto, execução e manutenção para os subsistemas prediais de coleta de água cinza e distribuição de água não potável;

- desenvolver uma ferramenta para análise de risco qualitativa do modo e efeito de falha para sistemas prediais de água não potável de edifícios residenciais;

- aplicar a ferramenta em um empreendimento residencial com sistema de água não potável.

\subsection{Metodologia da pesquisa}

Para atingir os objetivos do trabalho, realizou-se inicialmente o levantamento bibliográfico sobre o tema. Esse levantamento foi baseado em dois tipos de investigações: teórica e prática. $\mathrm{Da}$ investigação teórica, no que se refere aos requisitos de desempenho para os sistemas prediais de água não potável, obteve-se pouca contribuição. A maioria dessas publicações aborda os parâmetros físicos, químicos e microbiológicos referentes à qualidade da água e o sistema de tratamento ideal para o aproveitamento da água cinza, ou seja, temas que não faz parte do escopo desse trabalho.

Os requisitos de desempenho propostos para o sistema predial de água, também foram estudados durante essa fase da pesquisa. As publicações e notas de aula em que o tema é abordado referem-se ao sistema predial em que não existe a utilização de fonte alternativa de água.

Investigou-se também a legislação vigente nos países que possuem a prática da utilização da fonte alternativa de água disseminada, o que tornou possível analisar os critérios de projeto, execução e manutenção do sistema.

Com relação à investigação prática buscou-se informações com especialistas da área de sistemas prediais, com uma empresa que possui experiência na implantação do sistema de reúso e com fornecedores de estação de tratamento de água e esgoto. Com base nessas 
pesquisas foi possível propor os requisitos e critérios de projeto, execução e manutenção para o sistema predial de coleta de água cinza e distribuição de água não potável.

Os requisitos e critérios foram elaborados e, como existe a possibilidade dos envolvidos no projeto, execução e manutenção do sistema não aplicarem todos os requisitos propostos, optou-se em desenvolver a ferramenta de análise do modo e efeito de falha para cada um dos requisitos. A ferramenta tem como objetivo hierarquizar as falhas que podem ocorrer no sistema devido à inexistência de cada requisito e critério proposto. O resultado dessa aplicação auxilia os envolvidos, seja na fase projeto, execução ou manutenção na tomada de decisão dos requisitos e critérios a serem considerados no sistema predial de água não potável.

A finalização do trabalho ocorreu com a avaliação dos requisitos e critérios propostos em um edifício residencial. Os resultados obtidos tanto na fase teórica quanto na prática possibilitou a proposição de requisitos e critérios mais fundamentados e já aplicados em caso real. A Figura 1.1 apresenta a estrutura da pesquisa.

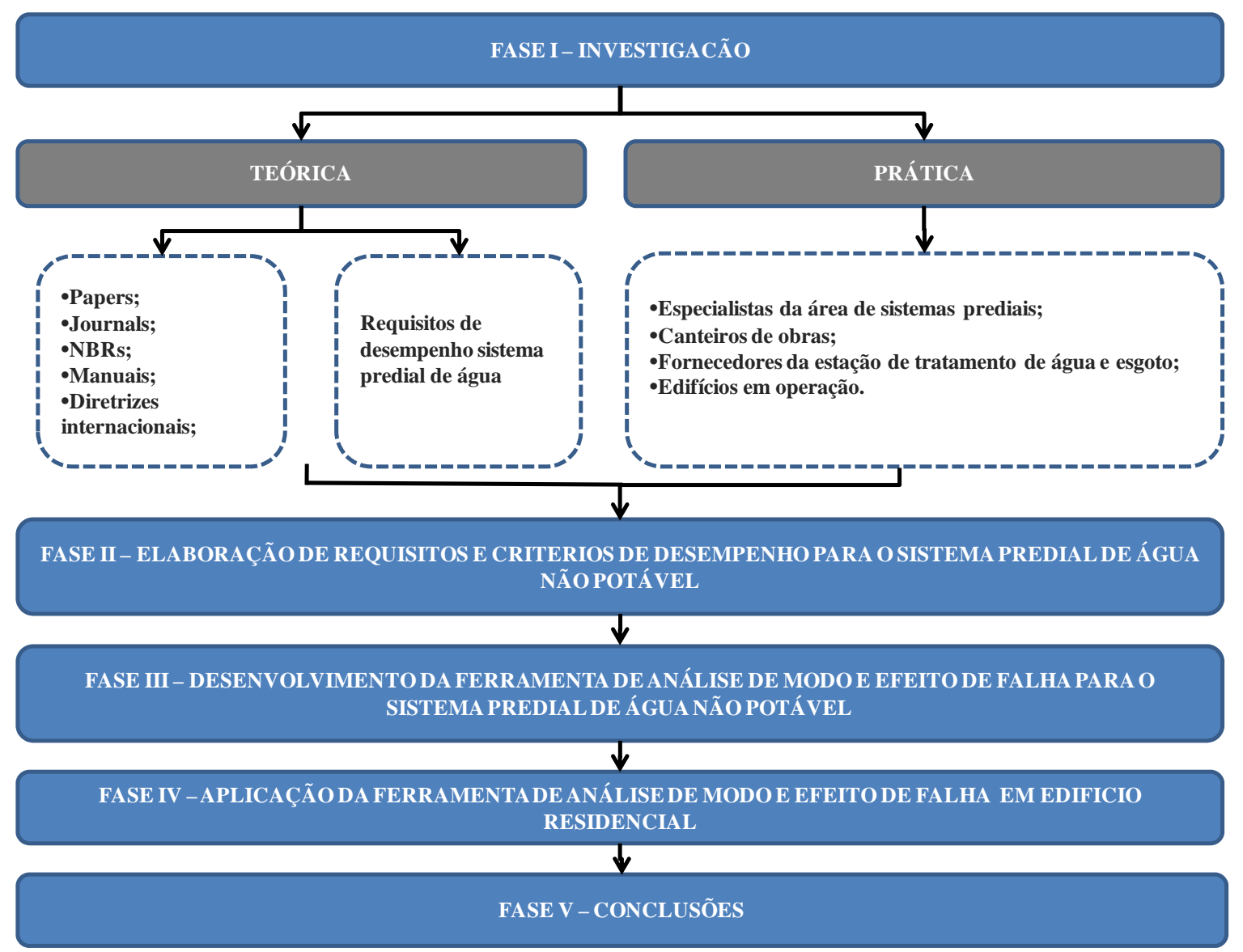

Figura 1.1 - Estrutura da pesquisa. 


\section{O SISTEMA PREDIAL DE ÁGUA}

Apresenta-se neste capítulo as principais diferenças entre o sistema predial de água que possui única fonte de abastecimento de água e o que possui duas fontes: a potável e não potável.

\subsection{O enfoque sistêmico}

Na concepção de Gonçalves (1997) o enfoque sistêmico apresenta-se através de um modelo sintético na abordagem dos problemas, sem desmembrá-los funcionalmente do sistema a que pertencem. Tornando possível explicar o todo, não excluindo a particularidade dos elementos.

Segundo Graça (1985) esse modo sintético é, portanto, mais abrangente do que o modo analítico, levando à soluções mais consistentes e adequadas de determinados problemas. Em alguns casos esta abordagem sintética permite a resolução de problemas de elevada complexidade, cuja solução não seria possível através de uma abordagem exclusivamente analítica.

Neste contexto, Gonçalves (1986) afirma “se desconsiderássemos esta visão ampla da questão, poderíamos, eventualmente, projetar um sistema ao qual o usuário devesse adaptarse. Assim, quando procuramos projetar, executar, operar e manter sistemas sanitários prediais que devam atender as exigências dos usuários, o uso do enfoque sistêmico e conseqüentemente o conceito de desempenho, torna-se ferramenta de extra-valia".

Sistemas prediais, conforme Gonçalves (2002) são sistemas físicos integrados a um edifício, e que têm por finalidade dar suporte às atividades dos usuários, suprindo-os com os insumos prediais necessários e propiciando os serviços requeridos. $\mathrm{O}$ autor ainda afirma que enfoque sistêmico está considerado nos sistemas prediais quando abordadas as necessidades dos usuários e conseqüentemente as funções para as quais o sistema é concebido (GONÇALVES, 1986).

O objeto da pesquisa refere-se à utilização de fonte alternativa de água em edifício residencial. As águas cinzas, oriundas do lavatório e chuveiro são tratadas e distribuídas como água não potável às descargas das bacias sanitárias. Diante desse ciclo, considera-se que a aplicação do enfoque sistêmico para esta tipologia de edifício, é uma tarefa indispensável, 
uma vez que cada um desses conjuntos, representados pela água cinza, estação de tratamento e água não potável interfere diretamente no resultado final do sistema. Desta forma, no sistema de fonte alternativa de água existe a influência da água cinza na concepção da estação de tratamento, na qualidade da água não potável e, por fim, na saúde dos usuários (Figura 2.1).

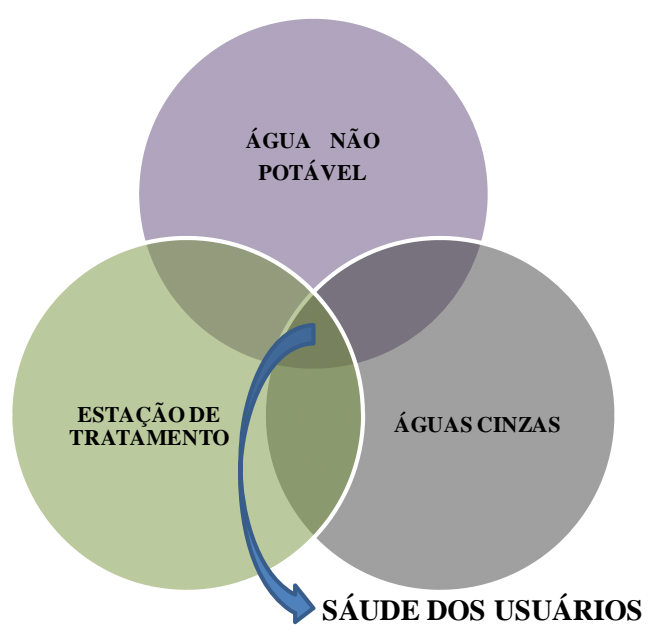

Figura 2.1 - Representação esquemática do enfoque sistêmico no sistema de fonte alternativa de água.

\subsection{Sistema predial de água não potável: coleta de água cinza e distribuição de água não potável}

O sistema predial de água tem a função de distribuir água para o edifício, bem como coletar os efluentes produzidos, dando a eles o seu destino adequado. Para realizar a especificada função, ele é composto pelo sistema de distribuição de água e pelo de coleta de efluentes.

Neste trabalho, são considerados dois tipos de sistemas prediais de água: o convencional e o que possui fonte alternativa de água. O sistema predial de água considerado convencional corresponde ao que possui única fonte de suprimento de água, a fornecida pela concessionária, e único sistema de coleta de efluente, que é destinado a rede pública de coleta de esgoto. Já o que possui a fonte alternativa de água instalada, tem dois sistemas de coleta de efluentes independentes e dois de distribuição de água. Tais sistemas estão descritos a seguir. 


\subsubsection{Subsistema predial de coleta de água cinza}

A fonte alternativa de água considerada neste trabalho, corresponde às águas cinzas claras depois de tratadas. Assim, o sistema de coleta é composto pela separação das águas cinzas, efluentes produzidos em lavatórios e chuveiros; das negras produzidas nos demais equipamentos sanitários. As águas cinzas são conduzidas para a estação de tratamento e as negras são direcionadas para a rede pública de coleta de esgoto (Figura 2.2).

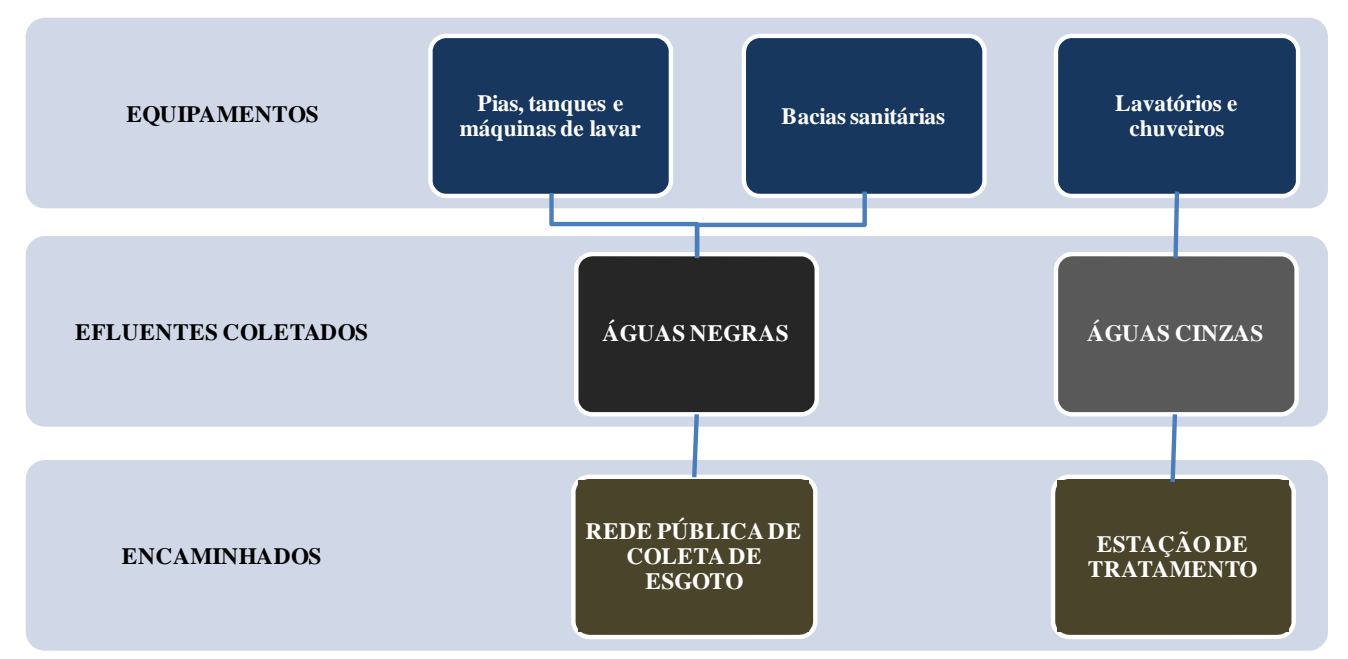

Figura 2.2 - Fluxograma das etapas do sistema de coleta de esgoto sanitário em edifício que possui a fonte alternativa de água oriunda dos lavatórios e chuveiros.

\subsubsection{Subsistema de distribuição de água não potável}

O sistema de distribuição de água, quando inserida a fonte alternativa de água, possui a fonte de abastecimento, originada da rede pública e a proveniente da estação de tratamento das águas cinzas (ETAC). A rede pública fornece a água potável para o edifício, que é distribuída para o lavatório, chuveiro, pia, tanque e máquina de lavar; enquanto que a estação de tratamento, instalada no edifício, distribui a água cinza tratada, denominada neste trabalho como água não potável, às descargas das bacias sanitárias. O fluxograma, apresentado na Figura 2.3, esquematiza o sistema de distribuição do edifício com as duas fontes de abastecimento de água. 


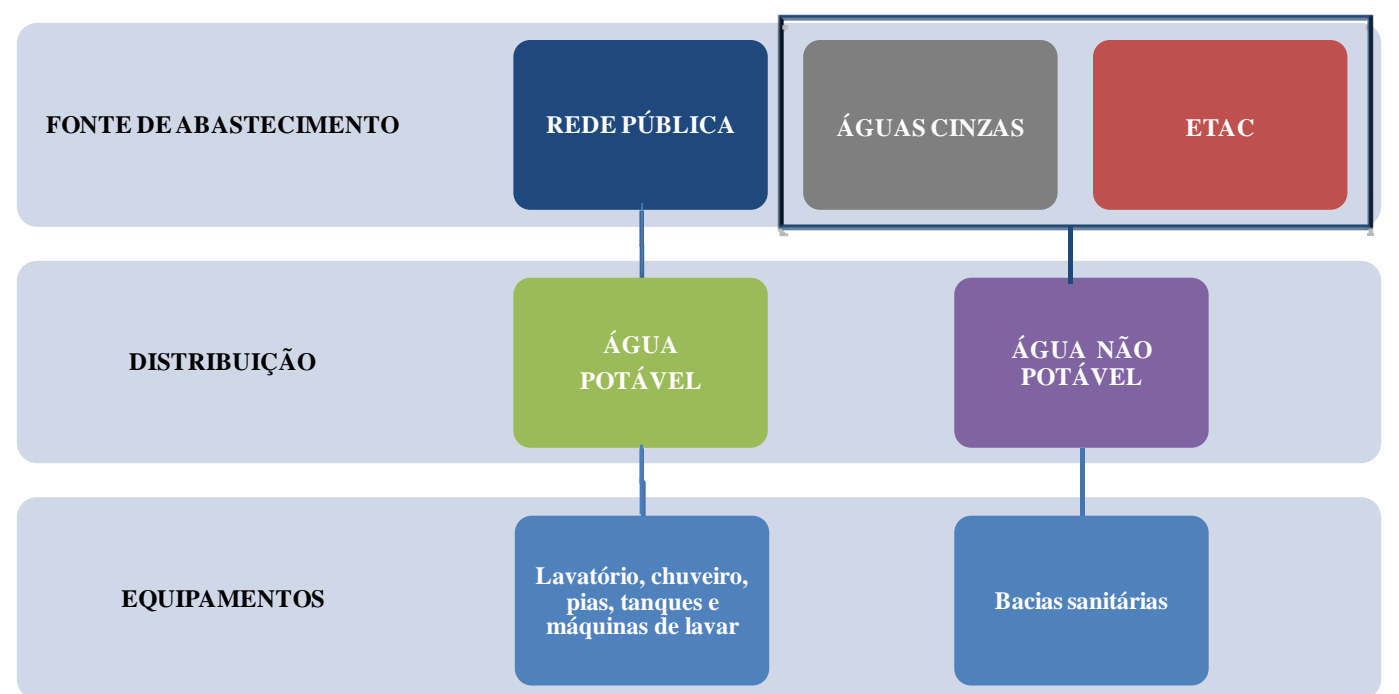

Figura 2.3 - Fluxograma representando o sistema de distribuição de água em edifício que possui a fonte alternativa de água.

Cabe ressaltar que a água cinza reutilizada corresponde ao efluente produzido apenas no lavatório e chuveiro, excluindo assim os demais equipamentos (pia, tanque, máquina de lavar roupa e louça). Essa separação é justificada por dois aspectos: primeiro, devido ao volume total de água cinza em edifícios residenciais ser superior à demanda das descargas das bacias sanitárias com caixa acoplada; e o segundo, devido à qualidade da água, visto que a pia da cozinha e a máquina de lavar louça contêm matéria orgânica e o tanque e a máquinas de lavar, sabão. Esses aspectos exigem um sistema de tratamento mais complexo, composto por mais etapas.

\subsection{Função dos sistemas prediais de água não potável}

Apresentados os sistemas de coleta de efluente e de distribuição de água no edifício em que existe a fonte alternativa de água instalada, conceitua-se o subsistema predial de coleta de água cinza (SPAC) e o de distribuição de água não potável (SPAN), que juntos formam o sistema predial de água não potável (Figura 2.4). 


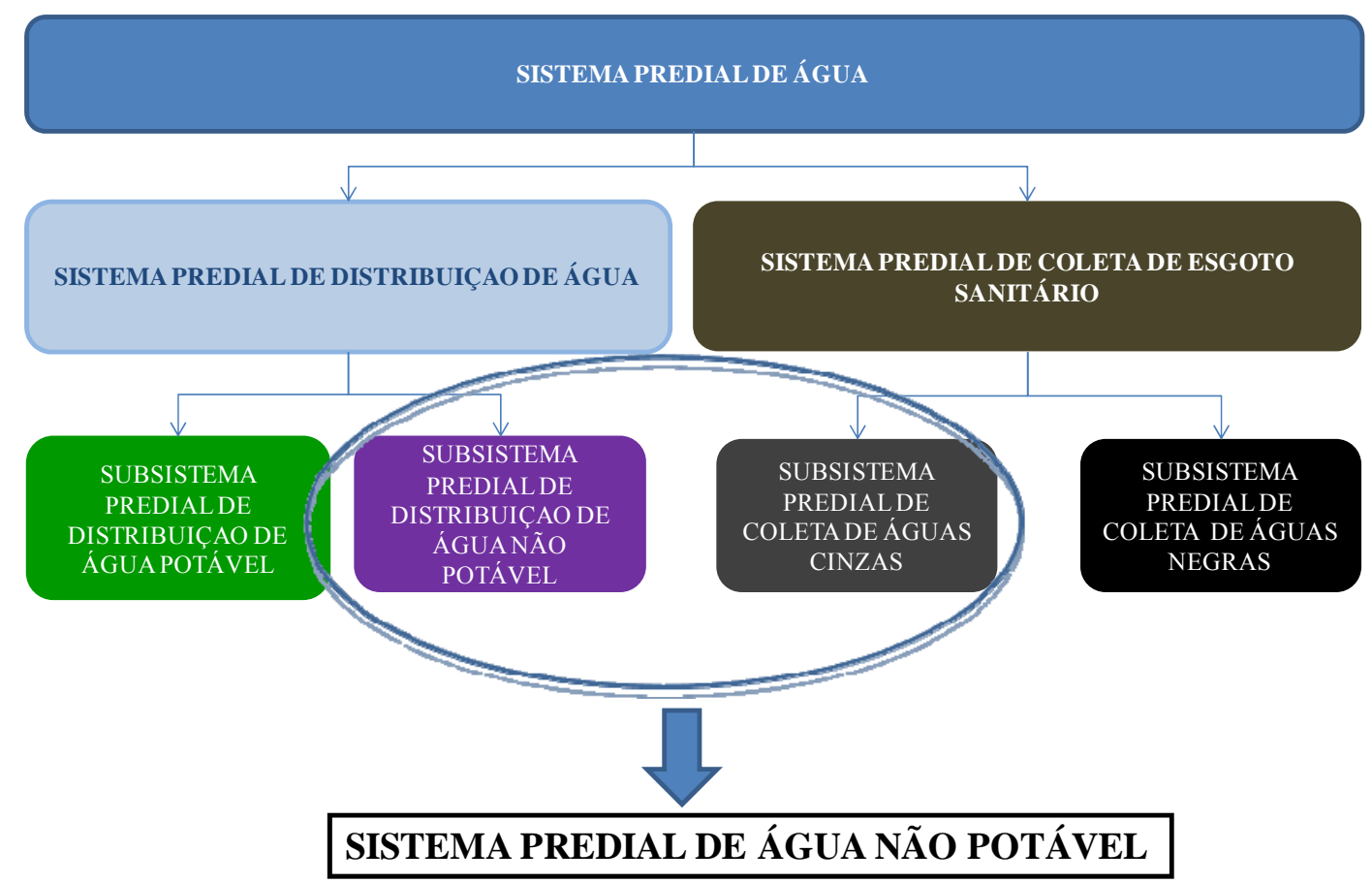

Figura 2.4 - Composição esquemática do sistema predial de água não potável.

O SPAC tem como função coletar os efluentes dos lavatórios e chuveiros e transportá-los ao seu destino adequado, seja a estação de tratamento seja a rede coletora de esgoto. Já o SPAN é responsável pela condução da água proveniente da estação de tratamento à descarga da bacia sanitária.

Como a estação de tratamento é projetada para tratar efluentes com características idênticas as existentes nas águas cinzas e torná-las em condições de uso nas bacias sanitárias, os sistemas prediais interligados com a estação tem a função de encaminhar apenas essas águas cinzas, bem como de distribuir a água não potável apenas às bacias sanitárias. 


\subsection{Componentes do sistema predial de água não potável}

Segundo a NBR 1575-1 (ABNT, 2008), componente é produto integrante de determinado elemento do edifício com forma definida e destinado a cumprir funções específicas. A seguir são apresentados os componentes do SPAC e do SPAN.

Os componentes do SPAC são semelhantes ao do sistema predial de coleta de esgoto convencional, tais como:

- ramal de descarga do lavatório e do chuveiro;

- $\quad$ ramais de esgoto, que recebem os efluentes dos ramais de descargas;

- $\quad$ tubos de quedas de águas cinzas;

- tubulação de ventilação e;

- coletores horizontais.

Os componentes desse sistema têm a função de encaminhar as águas cinzas oriundas do ambiente sanitário (banheiro) até à estação de tratamento ou à rede coletora de esgoto. A Figura 2.5 apresenta cada componente do subsistema e seu arranjo considerando a bacia sanitária. 

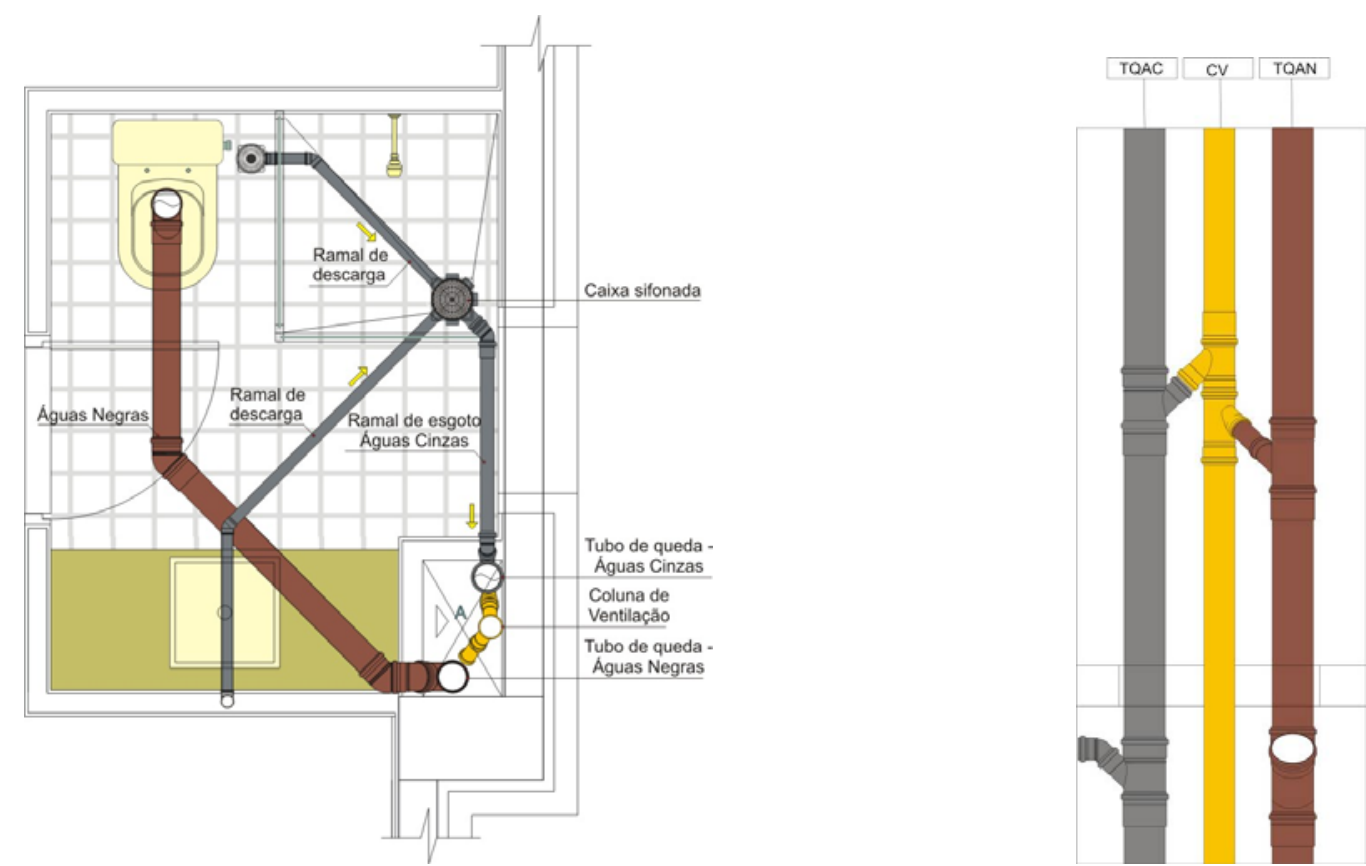

Figura 2.5 - Planta baixa e corte de banheiro residencial, apresentando componentes do SPAC.

A ventilação do SPAC é idêntica à do sistema predial de coleta de esgoto convencional, ou seja, apresenta os seguintes elementos: ventilação primária do tubo de queda de água cinza, ramal de ventilação e coluna de ventilação. A Figura 2.6 apresenta o esquema vertical de um SPAC de um edifício residencial, em que são reutilizados os efluentes gerados nos lavatórios e chuveiros. Nela estão considerados os seguintes componentes: ramal de esgoto, tubo de queda, coluna de ventilação e os subcoletores destinados a descartar as águas cinzas na estação de tratamento. 


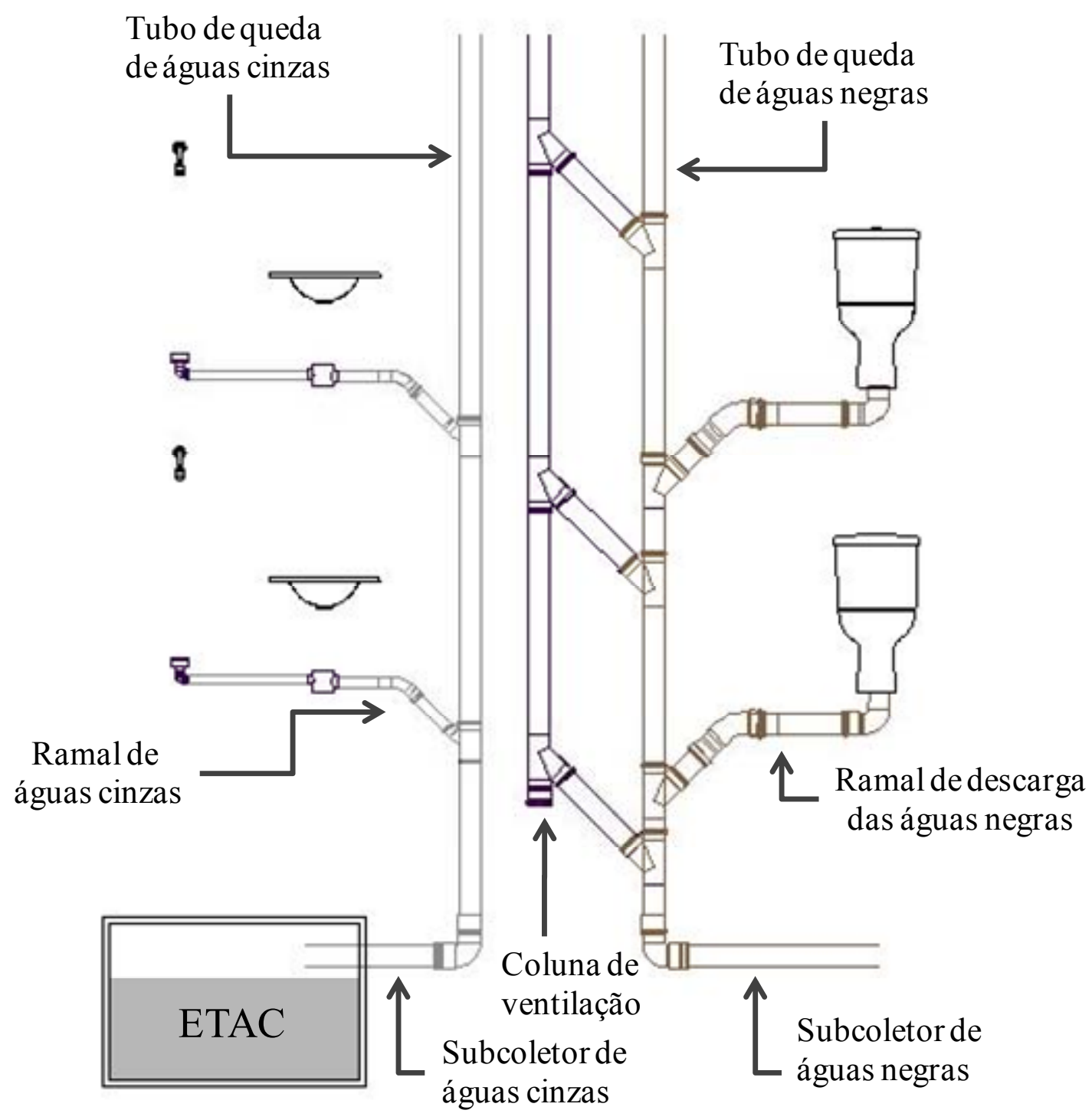

Figura 2.6 - Esquema vertical do SPAC do edifício residencial.

Além da tubulação, existe o tanque de equalização de água cinza que tem a função de receber os efluentes provenientes de lavatórios e chuveiros e armazená-lo para a estação de tratamento (ETAC).

Os componentes considerados no SPAN é o reservatório inferior e superior de água não potável, e a tubulação que distribui água não potável do reservatório à bacia sanitária, constituída pela coluna de distribuição, ramais e sub-ramais (Figura 2.7). 


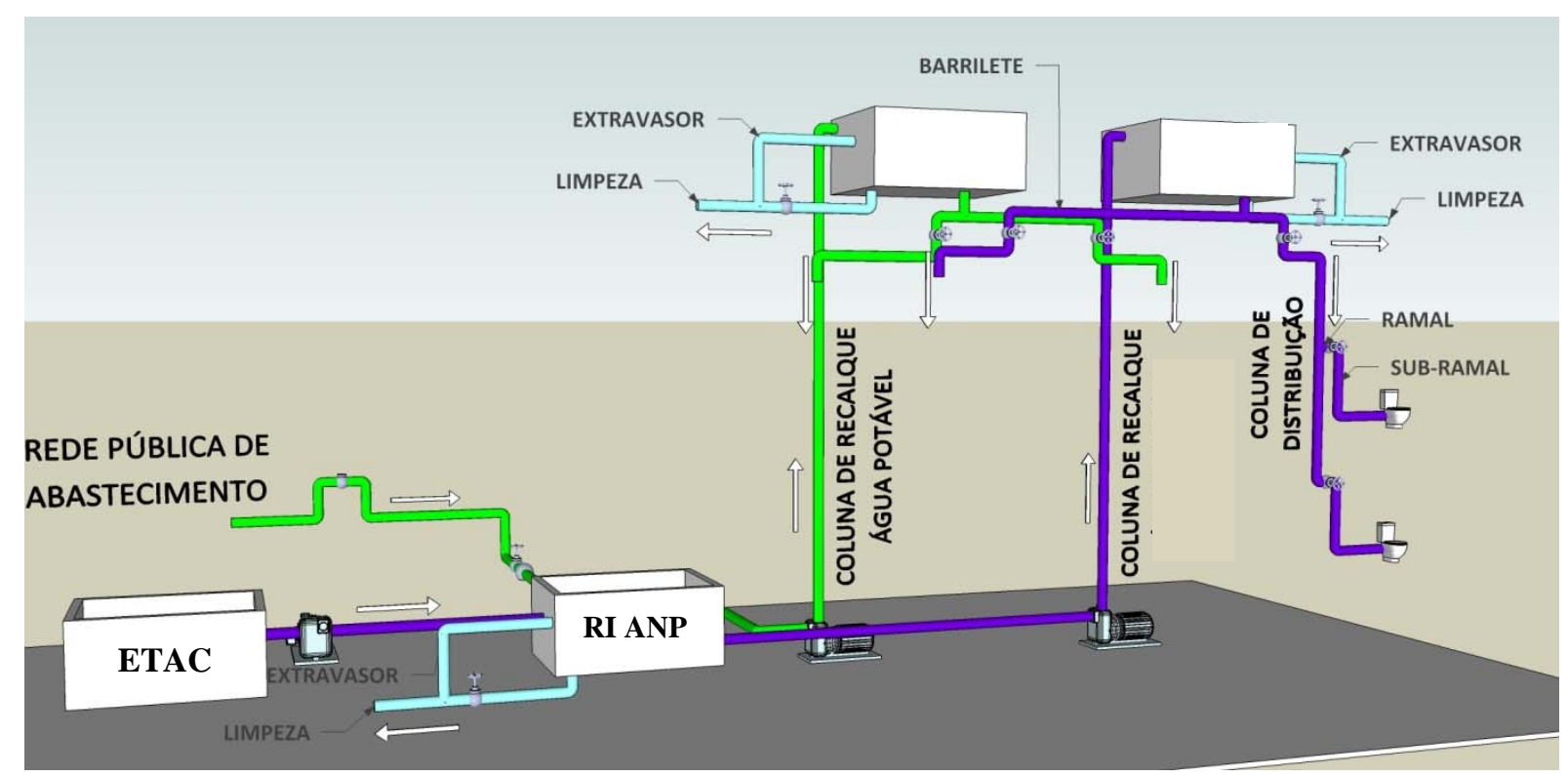

Figura 2.7 - Componentes do SPAN.

\subsection{Impactos da nova morfologia no edifício}

Como apresentado anteriormente, a implantação da fonte alternativa de água, oriunda do lavatório e chuveiro em bacia sanitária, requer um sistema duplo de coleta de efluentes e de distribuição de água, além de uma estação de tratamento. Estes sistemas impactam diretamente no projeto, nas atividades de execução, operação e manutenção desse edifício.

O traçado do sistema predial de coleta de esgoto sanitário diferencia do convencional, devido ao sistema duplo de coleta, que separa as águas cinzas das negras. Para isso, os ramais de descarga do lavatório e chuveiro, diferente do sistema convencional, não conecta com o da bacia sanitária e são interligados com o tubo de queda destinado a coletar apenas águas cinzas.

A separação entre os sistemas de coleta de água cinza e de água negra requer maior espaço físico para as tubulações. Além desse espaço, ainda deve ser considerada a área para instalar a estação de tratamento e realizar as devidas atividades de operação e manutenção.

O SPAN também necessita de maior área física para a sua instalação, tendo em vista a existência de dois sistemas de distribuição de água, o potável e o não potável, ou seja, dois sistemas independentes com armazenamento, recalque e distribuição de água. 
Descritas as diferenças dos sistemas prediais de água convencional e o que possui a fonte alternativa de água, o próximo capítulo apresenta os requisitos e critérios de desempenho para o sistema predial de coleta de água cinza (SPAC) e para o sistema de distribuição de água não potável (SPAN). 


\section{REQUISITOS DE DESEMPENHO DO SISTEMA PREDIAL DE ÁGUA NÃO POTÁVEL}

Este capítulo apresenta os requisitos e critérios de desempenho para o sistema predial de água não potável. Eles foram adaptados do sistema predial de água convencional e de diretrizes internacionais.

\subsection{Abordagem de desempenho - Conceituação}

Segundo Graça e Gonçalves (1986) uma das premissas para obter um projeto com qualidade é o atendimento aos requisitos de desempenho dos usuários, o que implica na satisfação das necessidades do usuário. A abordagem de desempenho segundo a comissão do CIB apud Graça (1985) considera as seguintes ações:

- caracterizar os usuários dos sistemas;

- definir as exigências e necessidades dos usuários;

- identificar as condições de exposição a que será submetido o sistema;

- definir os requisitos de desempenho;

- definir os critérios de desempenho;

- estabelecer os métodos para a avaliação do desempenho do sistema.

Essa abordagem permite o desenvolvimento de uma metodologia de projeto que viabiliza o desenvolvimento de novos produtos e materiais e, dentre outras finalidades, o controle do desempenho do sistema, razão pela qual, se pretende utilizar tal metodologia na proposta de projeto de fonte alternativa de água englobando as etapas essenciais para a elaboração do mesmo. 


\subsubsection{Caracterização dos usuários do sistema}

As atividades iniciais quando da abordagem de desempenho no projeto se dá com a caracterização dos usuários, os quais podem ser ocupantes do edifício, não ocupantes e não humanos, segundo Graça e Gonçalves (1986), ou seja:

- os ocupantes do edifício correspondem ao pessoal permanente, visitante, pessoal de limpeza e manutenção, etc;

- os não ocupantes do edifício correspondem aos construtores, proprietários, financiadores, administradores, vizinhos, etc;

- são considerados como usuários não-humanos os animais, a vegetação, equipamentos, máquinas, etc.

\subsubsection{Exigências e necessidades dos usuários}

As exigências e necessidades dos usuários dependem de cada edificação. Para identificá-las, devem-se considerar as atividades realizadas diariamente. Por exemplo, pode-se citar as atividades relacionadas com alimentação, higiene e saúde pessoal, higiene de objeto de uso pessoal, higiene ambiental, dentre outras.

\subsubsection{Condições de exposição do sistema}

Tais condições correspondem às ações que ocorrem devido à utilização, ao meio em que o sistema está inserido, bem como as influências no meio ambiente.

\subsubsection{Requisitos de desempenho}

A identificação dos requisitos de desempenho, segundo NBR 1575-1 (ABNT, 2008), consiste nas condições qualitativas que devem ser cumpridas pelo sistema, a fim de que as exigências dos usuários sejam satisfeitas.

\subsubsection{Critérios de desempenho}

Identificados os requisitos de desempenho, são estabelecidos os respectivos critérios necessários para atingí-los. Conforme a NBR 1575-1 (ABNT, 2008), critério de desempenho 
se apresenta como o "conjunto de especificações que visam representar tecnicamente as exigências do usuário".

As etapas anteriormente citadas devem ser cumpridas para garantir o desempenho de qualquer sistema predial. Assim sendo, é necessário estabelecer requisitos e critérios de desempenho do sistema predial de água não potável, o que não é abordado com ênfase pela literatura pertinente por se tratar de uma inovação tecnológica aplicada, especificamente, em algumas edificações e sem ampla divulgação técnica.

Rosrud (1980) desenvolveu os requisitos para os sistemas prediais de coleta de esgoto sanitário e de distribuição de água potável, porém não considera para o subsistema de coleta de água cinza e de distribuição de água não potável, que embora muito semelhantes ao sistema convencional apresentam particularidades. Para o sistema predial de água não potável, apesar de fazer uso dos requisitos do sistema predial de água, há que se considerar outros cuidados para garantir o adequado desempenho. Tais requisitos específicos, assim como os adaptados, são apresentados e comentados a seguir. Eles estão separados pelos subsistemas de coleta de água cinza e de distribuição de água não potável.

\subsection{Requisitos de desempenho para o subsistema predial de coleta de água cinza}

Graça e Gonçalves (1986) entende que o sistema predial de água deve coletar e destinar, quando necessário, a água nele introduzida, assim como os despejos provenientes do uso desta água, de maneira adequada. A Tabela 3.1 contempla os requisitos de desempenho adaptados de Rosrud (1980) e os critérios apresentados em EPA (2005), Acta (2005), BSRIA (2006), NSW (2005), NSW (2006) e WRAS (2006) publicados pela bibliografia internacional que devem ser considerados no subsistema predial de coleta de águas cinzas. Em seguida, cada requisito e seus respectivos critérios são detalhados para aplicação no subsistema predial de coleta de água cinza, de acordo com a sua fase de inserção no sistema, projeto, execução, operação e manutenção. 
Tabela 3.1 - Requisitos para SPAC e respectivos critérios.

\begin{tabular}{|c|c|c|}
\hline \multicolumn{2}{|c|}{$\begin{array}{l}\text { Requisitos de desempenho para o SPAC adaptado de } \\
\text { Rosrud (1980) }\end{array}$} & \multirow{2}{*}{$\begin{array}{l}\text { Critérios para o SPAC (EPA (2005), } \\
\text { Acta (2005), BSRIA (2006), NSW (2005), } \\
\text { NSW (2006);WRAS (2006) } \\
\text { - Coletar águas cinzas independente das } \\
\text { águas negras. }\end{array}$} \\
\hline $\begin{array}{l}\text { Qualidade da } \\
\text { água }\end{array}$ & $\begin{array}{l}\text { Evitar a contaminação da água cinza } \\
\text { coletada, de forma a garantir a qualidade } \\
\text { final da água tratada. }\end{array}$ & \\
\hline Disponibilidade & $\begin{array}{l}\text { Possibilitar que a água utilizada e os } \\
\text { despejos introduzidos através da utilização } \\
\text { normal, sejam conduzidos a destino } \\
\text { adequado. }\end{array}$ & $\begin{array}{l}\text { - Descartar o efluente na rede de esgoto } \\
\text { quando necessário. } \\
\text { - Instalar válvulas de limpeza em todos } \\
\text { os componentes da estação de tratamento. }\end{array}$ \\
\hline Acessibilidade & $\begin{array}{l}\text { Possibilitar o acesso à tubulação para } \\
\text { eventuais manutenções. }\end{array}$ & $\begin{array}{l}\text { - Possuir acesso à tubulação de esgoto } \\
\text { para inspeção a cada } 15 \text { m e, caso exista } \\
\text { curva de } 90^{\circ} \text { a inspeção deve ser após } 1,5 \\
\text { m. }\end{array}$ \\
\hline Adequabilidade & $\begin{array}{l}\text { Permitir que a água utilizada e os despejos } \\
\text { introduzidos escoem de forma conveniente } \\
\text { até o destino adequado. }\end{array}$ & $\begin{array}{l}\text { - Possuir diâmetro interno de no mínimo } \\
\text { de } 75 \mathrm{~mm} \text { para os tubos de queda.. }\end{array}$ \\
\hline $\begin{array}{l}\text { Quantidade de } \\
\text { água }\end{array}$ & $\begin{array}{l}\text { Conduzir a destino adequado a água } \\
\text { utilizada e os despejos introduzidos, através } \\
\text { da utilização normal, nas quantidades } \\
\text { produzidas pelos equipamentos sanitários. }\end{array}$ & $\begin{array}{l}\text { - Dispor de sistema de reservaçào com } \\
\text { capacidade de acordo com o volume } \\
\text { coletado. }\end{array}$ \\
\hline \multicolumn{3}{|c|}{ Requisito de condição de exposição } \\
\hline Odores & $\begin{array}{l}\text { Restringir o retorno dos odores provenientes } \\
\text { da instalação, em seu todo ou em partes, } \\
\text { haja vista estes causarem incômodos e } \\
\text { situações inoportunas aos usuários. }\end{array}$ & $\begin{array}{l}\text { - Instalar coluna de ventilação no } \\
\text { reservatório de coleta, para liberação dos } \\
\text { gases e no SPAC, se necessário. }\end{array}$ \\
\hline $\begin{array}{l}\text { Ataque } \\
\text { biológico }\end{array}$ & $\begin{array}{l}\text { Assegurar a não proliferação de bactérias, } \\
\text { fungos, dentre outras parasitoses que } \\
\text { ataquem os elementos constituintes dos } \\
\text { sistemas e representem riscos à saúde dos } \\
\text { usuários e cuja presença seja indesejável no } \\
\text { meio ambiente. }\end{array}$ & $\begin{array}{l}\text { - A estação de tratamento deve ser } \\
\text { construída com material não biodegradável. } \\
\text { - Não deve ser utilizado material } \\
\text { translúcido no reservatório, a luz incidente } \\
\text { pode propiciar o crescimento das algas. }\end{array}$ \\
\hline $\begin{array}{l}\text { Preservação da } \\
\text { natureza }\end{array}$ & $\begin{array}{l}\text { Assegurar e propiciar o equilíbrio } \\
\text { ecológico, bem como a conservação das } \\
\text { águas, mediante a destinação adequada da } \\
\text { água e dos despejos em geral. }\end{array}$ & $\begin{array}{l}\text { - Impermeabilizar o reservatório, pois } \\
\text { caso este esteja enterrado, não representará } \\
\text { riscos de contaminação do lençol freático. }\end{array}$ \\
\hline $\begin{array}{l}\text { Resistência } \\
\text { mecânica }\end{array}$ & $\begin{array}{l}\text { Suportar a ação de cargas estáticas e } \\
\text { dinâmicas provenientes de agentes internos } \\
\text { e externos do sistema. }\end{array}$ & $\begin{array}{l}\text { - Conceber reservatório capaz de suportar } \\
\text { a pressão hidrostática existente. }\end{array}$ \\
\hline Operação & $\begin{array}{l}\text { Propiciar a adequada operação dos } \\
\text { componentes e do sistema como um todo. }\end{array}$ & $\begin{array}{l}\text { - A estação de tratamento deve ser fácil } \\
\text { de operar. }\end{array}$ \\
\hline
\end{tabular}

Para melhor entendimento, primeiramente são apresentados os requisitos e critérios para o subsistema predial de coleta de água cinza e posteriormente os referente ao tanque de equalização de água cinza. 


\subsubsection{Requisito qualidade da água coletada}

O requisito qualidade é considerado a partir da coleta da água cinza independentemente da negra. A água negra tem influência significativa na água servida, diminuindo consideravelmente seu padrão de qualidade. Assim sendo, esta água deve ser evitada, já que o custo operacional para conferir-lhe qualidade satisfatória ao sistema de água não potável onera demasiadamente o tratamento. Portanto, a parcela de água a ser coletada para ser novamente servida, em fins específicos, abrange somente a água cinza. Logo, é necessário projetar um sistema destinado somente a água negra e outro para água cinza. As tubulações de coleta dos dois sistemas devem ser totalmente separadas desde os equipamentos sanitários e, no caso de água negra, ser descartada à rede de esgoto. A água cinza deve ser conduzida à estação de tratamento, com possibilidade de descarte do volume excedente.

A estação de tratamento disponível para uso em edificações é concebida para tratar águas cinzas, ou seja, efluentes provenientes de lavatórios e chuveiros, e disponibilizar água não potável com qualidade satisfatória para determinados fins. As águas negras, oriundas de bacias sanitárias, bem como da pia da cozinha, máquina de lavar louça, tanque e da máquina de lavar roupa, apresentam baixa qualidade, o que pode inviabilizar o atendimento do padrão mínimo estabelecido para o sistema de água não potável.

A execução dos sistemas de coleta de água negra e cinza requer especial atenção, haja vista a possibilidade de interligação inadequada das tubulações, uma vez que os profissionais em geral, não possuem qualificação relativa à operação deste sistema. Esta conjuntura requer a capacitação da mão-de-obra, abordando a importância em manter a separação dos sistemas de coleta e os riscos a que estarão sujeitos os usuários quando da ocorrência de conexão cruzada. Além da capacitação dos instaladores, é recomendável utilizar tubulações e conexões com características diferentes, o que impossibilita a interligação dos diferentes sistemas.

Outra forma de distinguir os sistemas é através de cor, isto é, a cada sistema de coleta é atribuída uma cor característica, a qual pode ser aplicada às tubulações previamente à instalação ou após a execução. A cor cinza é recomendada para o sistema de coleta de águas cinzas e a cor marrom para o de águas negras. 
A pintura da tubulação antes da instalação favorece os instaladores, pois há indicação visual dos distintos sistemas de coleta, minimizando o risco de interligações nas tubulações dos diferentes tipos de coleta.

O responsável pela execução das instalações deve ter ciência do projeto e também atentar para as peculiaridades da edificação que conterá os dois sistemas de coleta. Parte-se do pressuposto que o conhecimento minimiza o risco de haver conexões cruzadas entre os sistemas, evitando riscos à saúde dos usuários.

A atividade de manutenção, conforme Amorim (1997) é bastante realizada nos sistemas prediais hidráulicos e corresponde a $79 \%$ dentre os demais sistemas prediais. Considerando este alto número, afirma-se que também é necessário tomar medidas de segurança à saúde dos usuários durante essa atividade.

Sempre que houver manutenção dos sistemas de coleta, é necessária a realização de uma minuciosa vistoria do local que passou por intervenção, a fim de comprovar a inexistência de conexão cruzada e, assim, autorizar a utilização da edificação sem expor os usuários à riscos de saúde. Tal vistoria deve ser realizada pelo gestor da edificação, que deve ter conhecimento da tecnologia instalada para avaliar criteriosamente os reparos executados.

O projeto que contempla o sistema de coleta de água cinza e de distribuição de água não potável, além do sistema de coleta de água negra e de distribuição de água potável, deve conter todas as informações necessárias para que, durante a execução, não haja dúvidas quanto à distinção dos diferentes sistemas prediais a serem instalados. Desta forma, a probabilidade de falhas e erros nos sistemas de coleta e de distribuição é reduzida.

As diretrizes de execução devem estar detalhadas no memorial descritivo do projeto, idealizado por especialista no assunto. Tal documento não exime o engenheiro responsável pela implantação do sistema predial das responsabilidades de execução, principalmente no que se refere à separação dos sistemas de coleta e de distribuição, o que repercute na qualidade da água cinza a ser coletada para o seu específico uso.

\subsubsection{Requisito disponibilidade}

A flexibilidade em descartar o efluente passível de aproveitamento, na rede de esgoto ou no reservatório de coleta de águas cinzas consiste no critério de atendimento do requisito 
disponibilidade. O descarte do efluente é influenciado pelo funcionamento da estação de tratamento. Caso o equipamento esteja em período de manutenção é necessário que as águas cinzas sejam descartadas na rede de esgoto. Para isso é necessário instalar válvulas de gaveta que possibilitem ao usuário optar pelo descarte ou pela coleta de água cinza. A disposição e a acessibilidade dessas válvulas devem ser previstas na fase de projeto do sistema. Caso esta diretriz não seja considerada (inexistência de válvulas), o efluente acaba sendo armazenado no reservatório e, em de excesso de volume, a estação de tratamento sofrerá extravasamento, causando incômodos como a proliferação de vetores e odor desagradável no ambiente.

A instalação de válvulas de gaveta, ilustrada na Figura 3.1, deve ocorrer nas tubulações à montante do reservatório de coleta e elas devem ter características físicas que permitam a utilização em diâmetros a partir de $75 \mathrm{~mm}$ e com efluente que contenha sólidos na sua composição. Estas válvulas podem ser adquiridas de fabricante nacional, que as disponibilizam com diâmetros compatíveis com a tubulação de esgoto. A estanqueidade da válvula é garantida por cunha emborrachada.

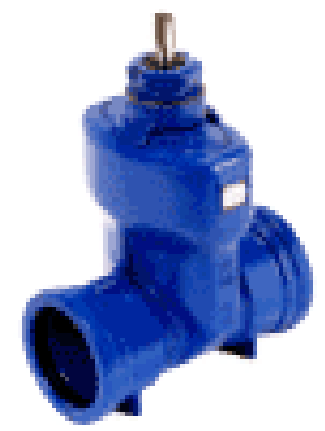

Figura 3.1 -Válvula de gaveta com cunha de borracha ${ }^{1}$.

No mercado internacional encontra-se disponível um modelo de válvula de três vias, conforme apresentado na Figura 3.2. Este componente é adequado para o emprego em sistema predial com coleta parcial de água cinza, por exemplo, em lavatório.

${ }^{1} \mathrm{O}$ fabricante da válvula foi acessado na página http://www.saintgobain.com em 2005. 
A figura 3.2 apresenta a aplicação da válvula na tubulação de esgoto de uma pia. Esta válvula permite e bloqueia a passagem do efluente para a rede de coleta de esgoto ou para a tubulação responsável pela irrigação do jardim.

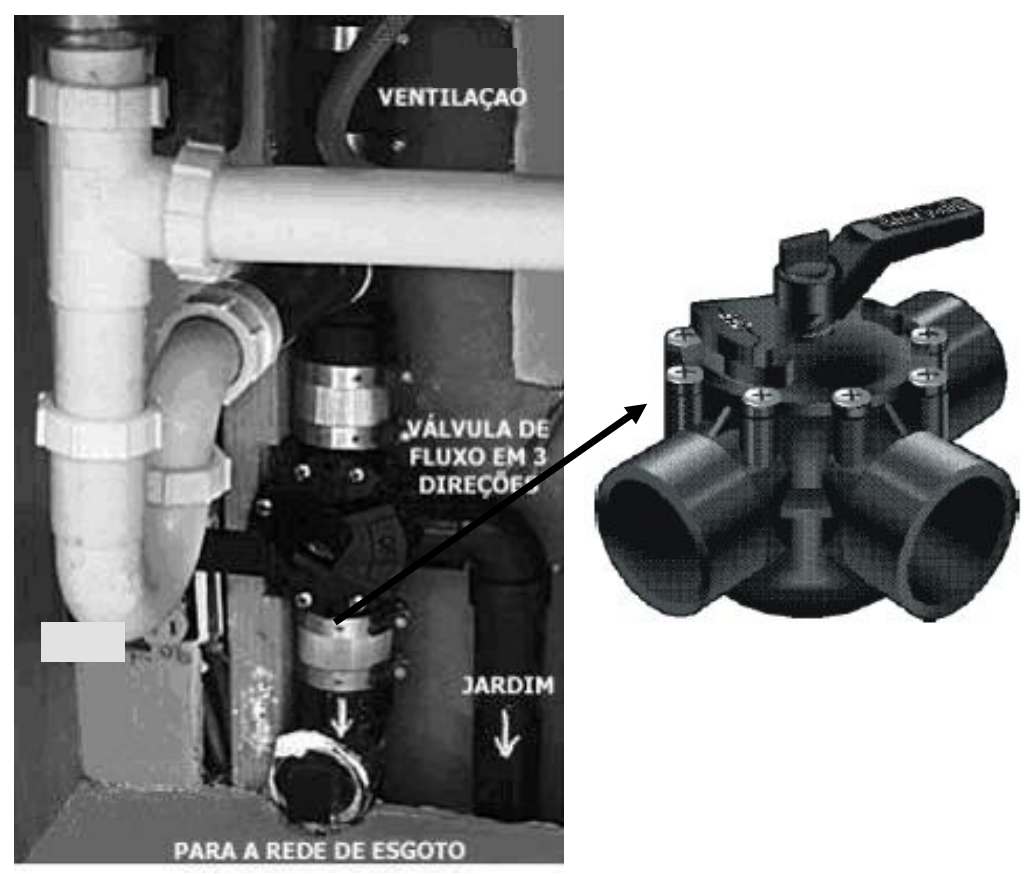

Figura 3.2-Válvula três vias controla o fluxo em duas direções² .

Como citado, a consideração da opção de coleta ou de descarte do efluente é extremamente importante para o sistema de utilização de água cinza. A coleta de águas cinzas requer a manutenção do sistema, de forma mais intensiva, principalmente no que se refere à limpeza do reservatório. O projeto deve contemplar as condições adequadas para a execução dessas atividades, permitindo o esgotamento do volume reservado para a rede de esgoto.

A água cinza, por conter sólidos na sua composição, propicia o acúmulo de resíduos no tanque de equalização que, com o passar do tempo, diminui a qualidade da água armazenada e, em conseqüência, prejudica o tratamento do efluente na estação. Caso não haja sistema de esgotamento do reservatório previsto em projeto, é necessário fazer a remoção do efluente por

\footnotetext{
${ }^{2} \mathrm{O}$ fabricante da válvula indicada foi acessado em 2005 na pagina http://www.jandy.com
} 
sistema de bombeamento. Em geral, esta atividade é realizada por empresa terceirizada, utilizando sistema de recalque com estocagem em caminhão-pipa, com posterior descarte do efluente em aterro sanitário.

A limpeza do reservatório, ao fazer uso de sistema de recalque demanda maior intervalo de tempo, além de gerar transtornos como a circulação de caminhão no entorno da edificação. Estes inconvenientes aumentam o período de tempo que a estação de tratamento fica sem operar e, desta forma, aumenta o consumo de água potável para atender a demanda normalmente suprida pela água cinza tratada.

O reservatório também deve conter um extravasor, adequadamente projetado em função da vazão de abastecimento do mesmo. Este cuidado visa eliminar qualquer possibilidade de transbordamento no entorno do reservatório, o que é extremamente inconveniente por se tratar de um efluente com odor desagradável. Este extravasor deve descartar o efluente no sistema de esgoto.

\subsubsection{Requisito acessibilidade do sistema de água cinza}

O projeto do sistema de água cinza deve abranger a acessibilidade à tubulação de coleta que permita sanar qualquer obstrução do sistema. A cada 15 metros deve estar previsto um ponto de inspeção quando se trata de tubulação e, nos locais onde há mudança de direção, o ponto de inspeção deve estar localizado, no máximo, após 1,5 metros desta. A não previsão de pontos de inspeção acarreta cortes na tubulação para eliminar qualquer fonte de obstrução, o que resulta em desperdício de material e de mão-de-obra.

A inspeção da tubulação de coleta é propiciada pela inserção de conexões que possibilite o acesso ao sistema. Na tubulação, o acesso é conseguido pela utilização de caps e, nas conexões, como curvas, junções, tês, através de plugs.

\subsubsection{Requisito adequabilidade e quantidade de água cinza}

A adequabilidade relaciona-se ao correto dimensionamento do sistema, pautado nas diretrizes de operação e desempenho. A tubulação do tubo de queda, com diâmetro mínimo de 75 mm, deve garantir o adequado escoamento do efluente até o destino final. $O$ inadequado dimensionamento acarreta a obstrução da tubulação, comprometendo sua eficiência por diminuir o volume de efluente a ser inserido na estação de tratamento. Também pode causar 
pressões negativas e positivas no interior da tubulação, resultando em comprometimento da integridade dos fechos hídricos do sistema.

O dimensionamento do sistema de coleta é realizado de acordo com a norma NBR 8160 (ABNT, 1998), que recomenda o método determinístico, a partir das Unidades Hunter de Contribuição (UHC) ou o método hidráulico. No método determinístico, os ramais e os tubos de queda são dimensionados de forma análoga ao do sistema predial de coleta de esgoto sanitário.

O dimensionamento dos subcoletores do sistema de coleta de águas cinzas segue as recomendações da NBR 8160 (ABNT, 1998), que considera para edifícios residenciais, a contribuição do equipamento de maior UHC. Exemplificando, no sistema convencional, o subcoletor de um banheiro que contém um lavatório, um chuveiro e uma bacia sanitária, terá diâmetro da tubulação de acordo com a contribuição da bacia sanitária, equipamento que possui maior UHC dentre os citados, com valor de 6,0 UHC. No sistema de coleta de águas cinzas, a bacia sanitária não é considerada, pois faz parte dos equipamentos que geram águas negras. Assim sendo, o chuveiro passa a ser o equipamento de maior contribuição, com valor de 2,0 UHC.

A otimização do dimensionamento pode ser obtida a partir do método hidráulico. Neste método são consideradas as reais vazões de esgoto sanitário dos equipamentos. Assim, sugere-se a utilização dos dois métodos para determinar as dimensões otimizadas dos componentes.

\subsubsection{Requisito odores e ataque biológico do sistema predial de coleta de água cinza}

Este requisito refere-se à condição de exposição do usuário e interfere diretamente no seu conforto. Como o sistema predial abrange o sistema de coleta de águas cinzas e a estação de tratamento é preciso prever a ventilação para estes sistemas. A ventilação pode ser instalada a partir da tubulação de ventilação do reservatório de coleta de efluentes, a qual pode ser acoplada à coluna de ventilação do edifício. Desta forma, a purga dos gases do interior do reservatório é realizada junto com os demais gases oriundos do sistema de esgoto sanitário, através da coluna de ventilação.

No caso da estação de tratamento situar-se distante da coluna de ventilação do edifício é possível adotar outra tipologia. A ventilação também pode ser feita por sistema de exaustão 
instalado no local que contém a estação, desde que o descarte não ocorra para a área de circulação de pessoas, haja vista o desconforto causado por odores desagradáveis.

A ventilação secundária pode ser excluída do sistema predial de coleta de águas cinzas desde que seja verificada a suficiência da ventilação primária do sistema conforme método hidráulico da NBR 8160 (ABNT, 1998). A suficiência da ventilação primária também foi pesquisada pelos seguintes autores: Santos (1998), Fernandes (2002) e Masini (1999).

A ventilação do sistema é necessária para evitar o rompimento dos fechos hídricos nos sifões do sistema. O rompimento pode ser causado pelo efeito da auto-sifonagem, bem como da sifonagem induzida e sobrepressão, devido a existência de pressão, negativa ou positiva ${ }^{3}$, no interior da tubulação. Esses fenômenos podem causar o efeito da sucção e compressão, provocado pelo bloqueio da passagem de ar no interior da tubulação.

Ressalta-se que o sistema predial de coleta de águas cinzas deve ser considerado semelhante ao de águas negras, pois o efluente produzido no banho pode possuir matéria fecal na sua composição, o que pode gerar mau cheiro no ambiente.

A seguir apresenta-se um caso ocorrido em edifício residencial na China, devido a inexistência desse requisito.

\section{- A Síndrome Respiratória Aquda e Severa}

Na China, no território de Hong Kong, em março de 2003, ocorreu a Síndrome Respiratória Aguda e Severa, também conhecida como SARS. Esta doença foi proliferada por meio do sistema predial de esgoto sanitário em um edifício residencial, que propiciou aos usuários a inalação de vírus, causando a morte de várias pessoas.

O Departamento de Saúde da China atribuiu à má instalação do sistema predial de esgoto a causa da proliferação da doença. Segundo Jack et al. (2005), o banheiro possuía um tubo de queda com abertura na sua extremidade superior, responsável pela coleta dos efluentes da bacia sanitária, do lavatório e do chuveiro; uma coluna de ventilação e um ramal de ventilação

\footnotetext{
${ }^{3}$ Pressão positiva corresponde a pressão superior a atmosférica e a negativa corresponde a inferior.
} 
que interligava o ramal de esgoto da bacia sanitária à coluna de ventilação, conforme apresentado na Figura 3.3.
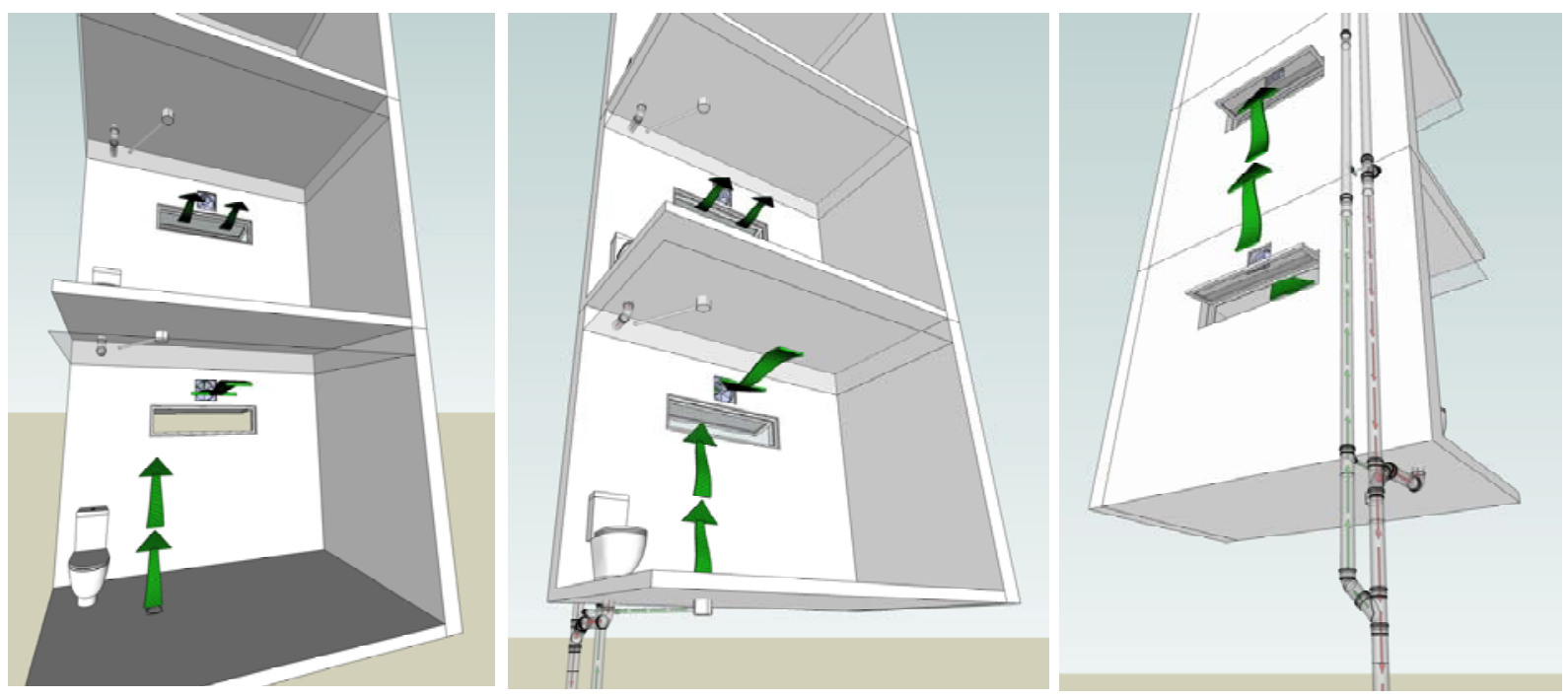

Figura 3.3 - Detalhe do sistema predial instalado no prédio contaminado.

A ventilação natural do ambiente era realizada por uma janela e a ventilação forçada por um sistema de exaustão, instalado acima da janela, com a função é succionar o ar do interior do banheiro para o exterior do edifício. A instalação dos sistemas de ventilação natural e forçada na mesma fachada caracterizou um erro de concepção, pois o ar contaminado era expelido pelo sistema de exaustão forçada possibilitando a entrada desse ar nos banheiros situados nos pavimentos superiores, através da ventilação natural.

A provável causa da contaminação, conforme afirma Jack et al. (2004), foi o acionamento da descarga da bacia sanitária utilizada por um usuário contaminado que, juntamente com a falha constatada nas caixas sifonadas, isto é, rompimento do fecho hídrico, propiciou a circulação do ar contaminado por diversos ambientes sanitários. A causa do rompimento dos fechos hídricos não é apresentada pelos autores, porém afirmam que o sistema de exaustão influenciou a ocorrência desta falha. As condições de contorno do sistema de coleta de esgoto e da ventilação natural e forçada dos banheiros contribuíram para a entrada dos gases contaminados do tubo de queda nos ambientes sanitários.

A falha no fecho hídrico e o acionamento do sistema de exaustão resultaram na sucção do ar ambiente e também dos gases do tubo de queda. Porém, no pavimento superior, a ventilação 
natural favorece a recirculação do ar contaminado no ambiente sanitário, principalmente se o sistema de exaustão estiver em funcionamento. Assim, a propagação do vírus ocorreu, seqüencialmente, nas demais unidades residenciais do edifício.

Desta forma, o sistema predial de coleta de esgoto e a ventilação, quando concebidos inadequadamente, interferem diretamente na saúde dos usuários. A disseminação da Síndrome Respiratória Aguda e Severa, anteriormente comentada, ocorreu a partir de erros que, muitas vezes, passam despercebidos, porém trazem resultados graves para a saúde dos usuários durante a utilização quando, sob determinadas condições, propiciam exposição severa às patologias.

A falha do sistema pode ocorrer na concepção do projeto, durante a execução, ou ainda, na manutenção. Cada uma destas etapas pode contribuir de alguma forma, para a ocorrência da exposição dos usuários a algum tipo de contaminação. Portanto, é preciso considerar todas as possibilidades de risco do sistema predial e também da edificação como um todo, a fim de prever medidas adequadas de segurança e, desta forma, garantir um desempenho compatível, principalmente, com a saúde dos usuários.

Apresentados os requisitos de desempenho para o sistema predial de coleta de água cinzas, a seguir são elaborados os relacionados com a estação de tratamento de águas cinzas. Ressalta-se que são apresentados apenas no âmbito predial, ou seja, onde existe a interferência com o sistema predial de coleta e de distribuição de água, já que não é objeto de estudo deste trabalho o tipo de tratamento.

\subsubsection{Requisito quantidade para estação de tratamento de água cinza}

O requisito volume de efluente a ser coletado refere-se à relação entre o volume de água cinza ofertado e a demanda necessária para abastecer as descargas das bacias sanitárias. A coleta de volume maior que o necessário influencia, na especificação da estação de tratamento e, em conseqüência, na viabilidade econômica do sistema.

A concepção da estação de tratamento com vazão maior que a necessária, além de onerar o custo do equipamento, interfere no dimensionamento do reservatório de coleta de água cinza. Além disso, implica em maior volume do reservatório de água não potável e maior espaço físico. Nesta situação, é necessário realizar o descarte do volume excedente tratado à rede de esgoto, gerando, além do custo de tratamento, o desperdício de água não potável tratada. 
Desta forma, a otimização do volume tratado em função do volume demandado traz benefícios econômicos para o sistema, tanto na aquisição, instalação e utilização, como na manutenção, evitando o armazenamento do efluente por período prolongado, o que deve ser evitado, pois a qualidade da água a torna passível de maus odores e proliferação de vetores patológicos.

A análise do volume de efluente demandado e ofertado deve ser realizada na fase de projeto do sistema. A demanda é determinada pelas variáveis inerentes aos hábitos dos usuários, abrangendo a freqüência e o período de utilização e a vazão dos equipamentos. O volume ofertado, determinado pela consideração das mesmas variáveis acima listadas, aplicadas aos equipamentos considerados geradores de água cinza passível de tratamento, quando maior que o volume demandado, deve ser descartado.

O volume excedente pode ser descartado quando se considera alguns equipamentos geradores de água cinza como geradores de água negra, ou seja, desviar do sistema de coleta de água cinza, parte do volume ofertado, eliminando-o diretamente no sistema de esgoto. Esta medida equaciona a oferta e a demanda, evitando o acúmulo de efluente que não será utilizado no sistema.

Uma alternativa mais simples e menos dispendiosa que a anteriormente citada, está em estabelecer o volume armazenado previamente ao tratamento. A compatibilização do volume ofertado com o volume demandado pode ser realizada no tanque de equalização, ou seja, pela instalação de um extravasor que limita o volume de efluente armazenado de acordo com a demanda da edificação.

A questão referente ao volume armazenado requer especial atenção em relação ao período de armazenamento. A água cinza, após 24 horas, pode iniciar o processo de biodegradação, com conseqüente liberação de mau cheiro e a possibilidade de proliferação de vetores no ambiente. Assim, como medida de segurança, é preciso descartar o efluente armazenado em intervalos de tempo não superiores a 24 horas.

Esta atividade pode ser realizada por um comando lógico programável (CLP), baseado no nível de água cinza tratada no reservatório inferior. Quando este encontra-se cheio, significa dizer que o reservatório superior contém água a ser utilizada e, nesta situação, não há necessidade de armazenamento de efluente. Logo, o descarte é acionado por válvula 
específica (eletromagnética) acionada pelo CLP. Em conjunto com este sistema, é preciso que o CLP disponha de um contador de tempo que, entre em funcionamento, assim que a válvula eletromagnética de descarte for fechada. Este contador, ao atingir um período de tempo de 24 horas deve, obrigatoriamente, eliminar o efluente armazenado.

Considerando-se que a água cinza coletada é oriunda dos chuveiros e lavatórios e, demandada, nas bacias sanitárias, o volume diário utilizado é, em geral, menor que o ofertado, o que implica em maior tempo de armazenamento da água cinza não tratada. Nesta situação, o descarte do efluente deve ser considerado com rigor no algoritmo do CLP que gerencia o sistema de coleta e distribuição de água não potável.

\subsubsection{Requisito ataque biológico para a estação de tratamento de água cinza}

A utilização de material translúcido nos componentes da estação de tratamento interfere, diretamente, no desenvolvimento de microorganismos. A luz solar ou artificial proporciona a proliferação de microorganismos contidos no efluente, interferindo no grau de poluição da água, ou seja, na qualidade da água servida a ser tratada e distribuída como não potável.

A estação de tratamento necessita atender os padrões de qualidade para viabilizar o uso da água cinza e, esta condição, depende, diretamente, das características do efluente a ser tratado. Assim sendo, o desenvolvimento acelerado de microorganismos pela incidência de luz pode não ser contornado pelo sistema de tratamento, isto é, haver deficiência em remover as bactérias do efluente, tornando-o inapropriado para a distribuição de água não potável por expor os usuários à riscos iminentes de contaminação. A presença, em alta concentração, de microorganismos no efluente, além de prejudicar a saúde dos usuários, pode reagir com o material dos tubos, conexões e peças, comprometendo a durabilidade dos componentes da estação de tratamento.

Portanto, a incidência de luz no efluente deve ser evitada e, para isto, deve-se fazer uso de materiais não translúcidos e de cores opacas que impeçam, na totalidade, a passagem da luz.

A adoção desses cuidados faz com que as reações de degradação do efluente e a proliferação dos microrganismos estejam de acordo com aquelas previstas em projeto, não comprometendo a qualidade do efluente tratado e a própria estação de tratamento. Os materiais e equipamentos certificados auxiliam quando da escolha e aquisição dos produtos, já que eles são testados de acordo com as normas pertinentes. 
Os tubos e conexões usualmente utilizados na execução do sistema predial de coleta de esgoto e distribuição de água potável podem ser empregados para a coleta da água cinza e distribuição de água não potável, atentando para as ressalvas de projeto, principalmente a conexão cruzada nos sistemas de distribuição e de coleta.

O sistema de tratamento de água cinza requer maior cuidado durante e escolha e especificação dos componentes, pois este sistema não é em geral disponibilizado no mercado e, portanto, não há credibilidade consolidada quanto aos materiais utilizados na sua fabricação. Assim, deve-se atentar para que não haja qualquer componente fabricado em material biodegradável, pois este irá interagir com o efluente coletado, diminuindo a vida útil do sistema. O menor tempo de utilização devido à degradação resulta em intervenção para manutenção, com ônus financeiro para os condôminos.

\subsubsection{Requisito preservação da natureza para estação de tratamento de água cinza}

A questão ambiental abordada neste requisito tem como objetivo alertar para os cuidados em relação à estação de tratamento enterrada. A principal exigência é a impermeabilização do sistema estrutural da estação. Esta estrutura em geral, de concreto deve, obrigatoriamente, evitar a infiltração do efluente no terreno, impossibilitando assim a contaminação do solo e das águas subterrâneas.

\subsubsection{Requisito resistência mecânica para estação de tratamento de água cinza}

A escolha do local de instalação da estação de tratamento, implica em uma série de exigências peculiares a serem atendidas para garantir o perfeito funcionamento do sistema e, sobretudo, a sua durabilidade. No caso da estação ser enterrada no solo, esta precisa suportar a pressão hidrostática do efluente contido no seu interior e, também, a pressão do solo. O mesmo serve para o reservatório de coleta de água cinza e o reservatório inferior de água não potável tratada. Portanto, a aquisição dos equipamentos que compõem a estação de tratamento depende da condição de instalação e, conseqüentemente, das características mecânicas das peças e componentes.

Também neste requisito, a escolha da estação e acessórios deve estar pautada em certificados, a fim de assegurar o nível de desempenho do sistema. As certificações garantem que os equipamentos foram devidamente testados nas condições à que se propõem e, desta forma, evitam intervenções precoces devido à não compatibilidade com a condição de instalação. 


\subsubsection{Requisito operação para a estação de tratamento de água cinza}

O sistema de coleta de água cinza, tratamento e distribuição de água não potável, implantado em um condomínio residencial, requer um gestor para a monitoração contínua dos parâmetros de qualidade. Em edifícios residenciais, as atividades rotineiras são realizadas, geralmente, pelo zelador do condomínio que, pode ou não, possuir grau de instrução adequado para gerenciar o novo sistema implantado. Diante desta realidade, os usuários podem ser expostos à riscos de saúde em função da operação da estação de tratamento ser realizada por mão-deobra não especializada.

Desta forma, a operação da estação de tratamento deve, obrigatoriamente, ser realizada por profissional capacitado, sob orientação de responsável técnico devidamente habilitado. Por questão de segurança, a estação de tratamento deve dispor de sistema automatizado que, em caso de qualquer falha, interrompa imediatamente o abastecimento de água não potável e, impeça a distribuição de água que não atenda os parâmetros de qualidade pré-estabelecidos.

Observa-se que o sistema predial de coleta de água cinza e tratamento possui particularidades que o difere consideravelmente do sistema predial convencional de coleta de esgoto sanitário. Os critérios a serem consideradas no projeto, execução, operação e manutenção do sistema são rigorosas e não podem ser tratadas com simplicidade, isto é, todas as etapas devem ser criteriosamente executadas para garantir a satisfação do usuário e, principalmente, garantir sua integridade física e mental.

Assim, o aperfeiçoamento contínuo deste novo sistema se faz necessária e, para isto, é preciso que os profissionais envolvidos com esta tecnologia tenham ciência da responsabilidade técnica acerca da saúde dos usuários conjugado com o menor consumo de água potável per capita.

\subsection{Requisitos de desempenho do sistema predial de água não potável}

Os requisitos de desempenho referentes ao subsistema de distribuição de água não potável abrange o pós-tratamento do efluente, isto é, o reservatório inferior, o sistema de recalque, o reservatório superior e o sistema de distribuição aos equipamentos que demandam a água não potável tratada, no caso, as bacias sanitárias. 
O sistema predial de água fria deve prover água de boa qualidade, em quantidade e temperatura controláveis pelo usuário, para a sua adequada utilização (Graça; Gonçalves, 1986). Os requisitos de desempenho propostos por Rosrud (1980) para este sistema, assim como as diretrizes internacionais para os sistemas de distribuição de água não potável (WRAS, 2006; NSW (2005), NSW (2006), BSRIA, 2006; Geórgia Department of Natural Resources, 2006; EPA Victoria, 2006) estão apresentados na Tabela 3.2.

Tabela 3.2 - Requisitos de desempenho e diretrizes internacionais para o SPAN.

\begin{tabular}{|c|c|c|}
\hline \multicolumn{2}{|c|}{$\begin{array}{c}\text { Requisitos de desempenho para o SPAN adaptado } \\
\text { de Rosrud (1980) }\end{array}$} & $\begin{array}{c}\text { Diretrizes para o SPAN (EPA (2005), Acta } \\
\text { (2005), BSRIA (2006), NSW (2005), NSW } \\
\text { (2006), WRAS (2006) }\end{array}$ \\
\hline $\begin{array}{l}\text { Qualidade da } \\
\text { água }\end{array}$ & $\begin{array}{l}\text { O sistema deve possibilitar que a } \\
\text { água entregue no ponto de } \\
\text { utilização, seja de boa qualidade. }\end{array}$ & $\begin{array}{l}\text { - Utilizar material que preserve a qualidade da } \\
\text { água. } \\
\text { - Utilizar na tubulação de água não potável } \\
\text { material diferente da tubulação de água potável. }\end{array}$ \\
\hline Operação & $\begin{array}{l}\text { O sistema deve operar com } \\
\text { segurança para não prejudicar a } \\
\text { saúde dos usuários. }\end{array}$ & $\begin{array}{l}\text { - Monitorar periodicamente da qualidade da água } \\
\text { após a estação de tratamento de águas cinzas } \\
\text { (ETAC). } \\
\text { • Distanciar as tubulações dos fluidos de } \\
\text { diferentes qualidades; } \\
\text { - Programação visual: sinalizar o sistema, nas } \\
\text { tubulações a cada } 3 \text { metros; pintar o sistema de } \\
\text { água não potável na cor roxo. } \\
\text { - Pigmentar o efluente tratado. } \\
\text { - Elaborar guia de operação e manutenção do } \\
\text { sistema. } \\
\text { - Inspecionar a tubulação executada para } \\
\text { verificação da separação dos sistemas prediais. }\end{array}$ \\
\hline $\begin{array}{l}\text { Quantidade de } \\
\text { água }\end{array}$ & $\begin{array}{l}\text { Deve-se garantir que a água seja } \\
\text { entregue no ponto de utilização em } \\
\text { quantidade suficiente. }\end{array}$ & $\begin{array}{l}\text { - Prever a fonte de água potável no reservatório } \\
\text { de água não potável. }\end{array}$ \\
\hline
\end{tabular}

Os requisitos apresentados na Tabela 3.2 são detalhados a seguir. Cabe ressaltar que o requisito operação complementa o requisito qualidade, pois no caso de ocorrer uma falha operacional haverá comprometimento da qualidade da água e, conseqüentemente, risco à saúde dos usuários.

\subsubsection{Requisito qualidade da água não potável}

Este requisito é atendido a partir da utilização de materiais em conformidade com as respectivas normas técnicas, utilização de tubulações com diferentes características estruturais, monitoração da qualidade da água não potável e pela previsão de mínima distância 
entre os sistemas prediais. Cada um dos critérios citados está apresentado e explicado a seguir.

\section{- Materiais em conformidade com as normas técnicas}

A qualidade da água não potável a ser servida sofre influência do material utilizado nas tubulações, por isso recomenda-se a utilização de tubos e conexões em conformidade, garantia de adequado desempenho durante a vida útil.

\section{- Materiais com diferentes características do SPAP ${ }^{4}$}

Os tubos e conexões que compõem o sistema predial de água não potável têm características semelhantes aos de água potável. Portanto, por questão de segurança, recomenda-se a utilização de materiais que possuam características estruturais diferentes para cada sistema, de modo que impossibilite a interligação entre os as tubulações de água potável e não potável, evitando assim a conexão cruzada.

\section{- Monitoração da qualidade da água}

A tubulação do subsistema de distribuição de água não potável tem importância no requisito qualidade, porém a principal diretriz a ser atendida refere-se à qualidade da água não potável. O controle desta qualidade requer o monitoramento periódico da água durante as atividades de operação e manutenção do sistema. A determinação das características físicas, químicas e biológicas da água não potável é extremamente importante para garantir as exigências mínimas para o consumo, sem expor os usuários à riscos de saúde. Caso seja detectada qualquer incompatibilidade com os padrões especificados, o sistema deve ser imediatamente paralisado para sanar a falha.

Considerando a inexistência de normas nacionais especificando a monitoração dos padrões de qualidade para uso de água não potável em bacias sanitárias, propõe o publicado pela EPA (2005). Além de respeitar esses padrões, a análise da água deve ser realizada por profissionais habilitados que devem emitir um relatório contendo os padrões especificados e os valores

\footnotetext{
${ }^{4}$ SPAP (sistema predial de água potável)
} 
determinados na amostra de água. Os padrões recomendados pela EPA (2005) são apresentados na Tabela 3.3.

Tabela 3.3 - Monitoração da qualidade do efluente tratado. FONTE: EPA (2005).

\begin{tabular}{|c|c|c|}
\hline $\begin{array}{c}\text { Padrões de qualidade para o } \\
\text { reúso em bacias sanitárias }\end{array}$ & Método de análise & Freqüência da análise \\
\hline \hline $\mathrm{DBO}_{5} \leq 10 \mathrm{mg} / \mathrm{l}$ & Laboratoriais (AWWA) & Semanalmente \\
\hline $\begin{array}{c}\text { Turbidez } \leq 2 \mathrm{UT} \text { (unidade de } \\
\text { turbidez) }\end{array}$ & Sensores ou laboratoriais & Semanalmente \\
\hline $\mathrm{pH}$ entre 6,0 e 9,0 & Sensores ou laboratoriais & Diariamente \\
\hline $\begin{array}{c}\text { não apresentar coliformes em } 100 \\
\text { ml de amostra de água }\end{array}$ & Laboratoriais (AWWA) & Diariamente \\
\hline Cloro (ativo) $\geq 1 \mathrm{mg} / 1$ & Sensores ou laboratoriais & Diariamente \\
\hline
\end{tabular}

Além da publicação da EPA (2005) referente aos métodos de análise da água não potável a ser servida, há as recomendações apresentadas na publicação New South Wales Code of Practice Plumbing and Drainage (2006), também pautadas na análise da água não potável tratada. A Tabela 3.4 apresenta a rotina de análises a ser realizada logo após a instalação, nas intervenções de manutenção e, também, durante a operação da estação de tratamento de águas cinzas.

Tabela 3.4 - Freqüência das análises iniciais e para manutenção da ETAC. FONTE: NSWaa 2006.

\begin{tabular}{|c|c|c|}
\hline \hline Parâmetro & Quantidade & Freqüência de Análises \\
\hline \hline Coliformes termotolerantes & $1 / 100 \mathrm{ml}$ & Quinzenalmente \\
\hline Coliformes totais & $<10 / 100 \mathrm{ml}$ & Quinzenalmente \\
\hline Cryptosporidium & $<1 / 50 \mathrm{~L}$ & Semanalmente \\
\hline Giárdia & $<1 / 50 \mathrm{~L}$ & Semanalmente \\
\hline Turbidez & $<2 \mathrm{NTU}$ & Ininterruptamente \\
\hline Cloro livre & $<5 \mathrm{mg} / 1$ & Ininterruptamente \\
\hline $\mathrm{pH}$ & Cloro livre $6,5-8,0$ & Ininterruptamente \\
\hline Sólidos suspensos & $<10 \mathrm{mg} / 1$ & Semanalmente \\
\hline $\begin{array}{c}\text { Demanda bioquímica de oxigênio } \\
\left(\text { DBO }_{5,20} \text { ) }\right.\end{array}$ & $<10 \mathrm{mg} / 1$ & Semanalmente \\
\hline
\end{tabular}

A coleta de amostras de água e o encaminhamento ao laboratório, atividades manuais, não isentam a possibilidade da utilização de sensores apropriados para medir, automaticamente, alguns parâmetros de qualidade da água. A análise de características da água em tempo real, por sensoriamento, propicia ao usuário um maior grau de confiabilidade e segurança, pois 
qualquer alteração em relação aos padrões especificados, a estação é imediatamente paralisada.

No Brasil não há recomendações ou normas que preconizem a implantação de fonte alternativa de água em condomínios residenciais. Esta carência faz com que os gestores assumam a responsabilidade quanto ao sistema, o que necessita de ampla divulgação acerca da tecnologia instalada na edificação. As informações sobre a utilização do sistema devem ser transferidas a todos os moradores e, de preferência, haver documentação que comprove a ciência de todos os usuários e possíveis riscos à que estarão expostos quando utilizar, inadequadamente, esta fonte alternativa de água.

\section{- Separação de tubulações}

O documento Guidelines for water reuse (EPA, 2004) preconiza as distâncias mínimas entre as tubulações de água potável, não potável e esgoto. Com o objetivo de evitar a interação entre elas em caso de vazamento. As tubulações instaladas no mesmo nível devem estar separadas por distância mínima de 0,90 metros, quando se trata de água potável e não potável. A instalação em níveis diferentes requer distância mínima de 0,46 metros, independentemente do subsistema. Entretanto, a tubulação de água potável deve, obrigatoriamente, estar instalada no nível mais alto, seguido da água não potável e, por último, o esgoto, conforme apresentado na Figura 3.4.
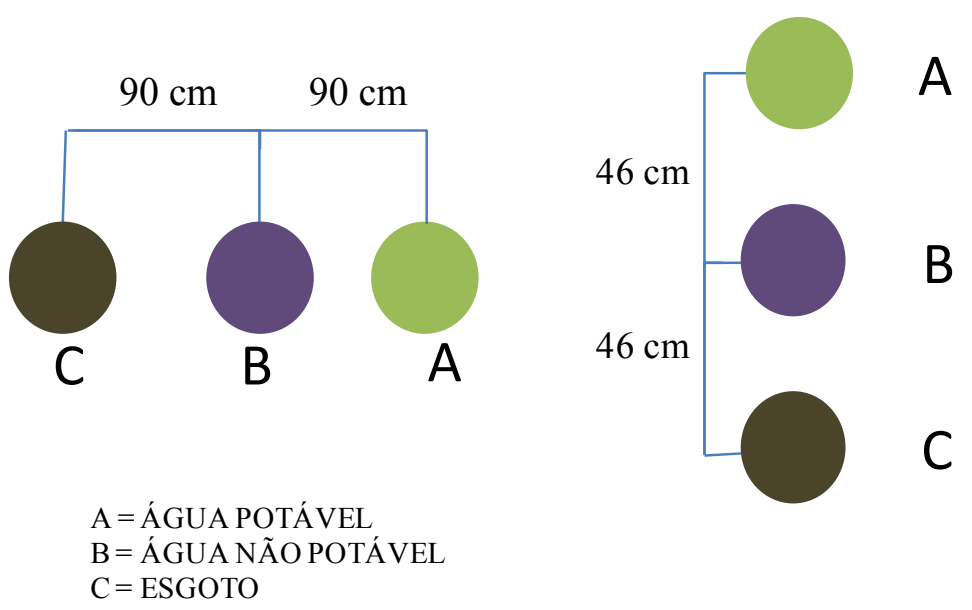

Figura 3.4 - Separação horizontal e vertical entre as tubulações dos sistemas prediais de água adaptado EPA (2004). 
Em caso de indisponibilidade física para atender as distâncias mínimas recomendadas pela EPA (2004) as autoridades competentes devem ser informadas para analisar o caso e, assim, propor uma adequada solução dentro das condições locais existentes.

A instalação de reservatório de água potável e de água não potável diretamente no solo requer distanciamento lateral mínimo para uma tubulação que transporta água de menor qualidade ou esgoto. Esta distância é a mesma recomendada para as tubulações instaladas em mesma cota ou seja, 0,90 metros conforme preconiza a EPA (2004).

\subsubsection{Requisito operação para não prejudicar a saúde dos usuários}

Para atender esse requisito deve-se considerar os critérios relacionados à identificação do sistema pela programação visual, pintura da tubulação e pigmentação da água não potável. Além desses critérios, deve ser elaborado para os usuários, o guia de operação do sistema. Cada critério encontra-se explicado a seguir.

\section{- Programação visual: identificação do sistema}

A programação visual da tubulação de água não potável é uma diretriz importante a ser realizada para atender o requisito operação do sistema.

Considerando-se que os materiais utilizados, bem como as dimensões das tubulações, podem ser os mesmos verifica-se grande probabilidade de ocorrência de conexão cruzada. A programação visual é uma forma adequada de minimizar a interligação indesejada e, contempla a pintura dos tubos e conexões, assim como a indicação por placas e adesivos que destaquem a distribuição de água não potável por esta tubulação. As placas e adesivos são colocados ao término da construção do edifício, enquanto que, a pintura deve ser realizada previamente à execução, na cor roxa. A tinta utilizada na pintura deve ser acrílica ou esmalte, semelhante à utilizada em tubulações de PVC instaladas em áreas externas.

A sinalização, por meio de placas e adesivos deve conter dizeres como: "água não potável", “imprópria para consumo", "não beber", etc. A identificação na tubulação realizada, por exemplo, com adesivos, deve ser prevista nas tubulações de todos os ambientes e a cada 3,0 metros. As placas, de maior apelo visual, devem ser instaladas em locais de fácil visualização e com cores vibrantes para chamar a atenção do leitor. 


\section{- Programação visual: pintura da tubulação}

A NBR 6493 (ABNT, 1994) especifica a cor da pintura das tubulações de acordo com o fluido transportado, recomendando para a água potável, a cor verde; para o esgoto sanitário, a cor marrom e; para a água pluvial, o verde escuro. A água não potável não é contemplada nesta norma, deixando a escolha da cor da pintura a cargo do projetista do sistema. A autora recomendou, previamente, a cor roxa para tubulação de água não potável e o manual WHO (2007) sugere que a tubulação seja pintada de lilás e os dizeres de alerta (“água não potável”, “imprópria para o consumo", “não beber”, etc), impressos na cor preta, com tamanho de fonte mínimo de $12,7 \mathrm{~mm}$. O tamanho da fonte varia de acordo com o diâmetro externo da tubulação, conforme apresentado na Tabela 3.5.

Tabela 3.5 - Dimensões das letras de acordo com o diâmetro da tubulação. FONTE: WHO (2007).

\begin{tabular}{|c|c|}
\hline \hline Faixa de diâmetro externo (mm) & Tamanho de letra mínimo (mm) \\
\hline $13-32$ & 12,7 \\
\hline $40-50$ & 19,1 \\
\hline $65-150$ & 32,0 \\
\hline $200-250$ & 64,0 \\
\hline$>250$ & 89,0 \\
\hline
\end{tabular}

$\mathrm{Na}$ Austrália, é exigida a contratação de profissionais credenciados para a execução do sistema de água não potável (NSW, 2006). No Brasil, esta obrigatoriedade não é regulamentada e, com isso, há prestadores de serviço que executam a instalação sem conhecimento técnico. Nesta situação, falhas podem ocorrer por falta de treinamento e qualificação, com conseqüente exposição dos usuários à condições inadequadas de utilização do sistema, ou seja, risco iminente à saúde.

\section{- Pigmentação da água não potável}

A operação do sistema de distribuição de água não potável deve contemplar a pigmentação da água servida, por questão de segurança. A interligação indesejada, ou seja, a conexão cruzada do sistema de água potável e da não potável caracteriza um risco grave aos usuários, o que pode passar despercebido por um longo período de tempo. A pigmentação visa sanar este inconveniente, já que a identificação da falha ocorre imediatamente após qualquer intervenção no sistema. 
O projeto de distribuição de água não potável tem por objetivo atender a demanda, única e exclusivamente, das bacias sanitárias do conjunto residencial e, com isso, apenas nestes equipamentos é que deve-se observar a presença de água pigmentada. Caso haja fornecimento desta água em qualquer outro equipamento, o sistema deve ser paralisado imediatamente, tendo-se em vista a ocorrência de conexão cruzada, facilmente identificada, porém de localização desconhecida.

A pigmentação da água não potável deve ser contínua, pois, em muitos casos, os proprietários fazem intervenções no sistema hidráulico da sua unidade sem informar adequadamente a administração do condomínio. Esta intervenção, em geral, é realizada por profissionais que não têm conhecimento do sistema de água não potável e, assim, pode haver a possibilidade de contaminação do sistema de água potável por conexão cruzada. A pigmentação esporádica da água não potável, com intervalos pré-estabelecidos, é uma opção de controle da conexão cruzada, porém acarreta inconveniência aos moradores, pois todos deveriam acionar todos os equipamentos hidráulicos residenciais durante o teste do sistema para identificar possíveis falhas.

O corante indicado para a pigmentação da água não potável é o mesmo utilizado na composição de detergentes líquidos e sabonetes. Estes produtos são pigmentados com corantes de classe ácida e amplamente utilizados na limpeza de chuveiro, bacia sanitária, pia e lavatório, sem causar danos na aparência visual (manchas) das peças cerâmicas e louças sanitárias. A grande aceitação desses produtos no mercado indicam que o corante utilizado em sua composição não deteriora a tubulação, como também o reservatório de armazenamento de água pigmentada. Assim, sugere-se a utilização deste tipo de corante para a identificação da água não potável.

\section{- Elaboração do guia de operação}

As diretrizes até aqui comentadas mostram a complexidade acerca da utilização de água não potável em edifício residencial e os riscos decorrentes de uma falha. O amplo esclarecimento dos usuários é de suma importância e deve ser realizado através da elaboração de um manual e guia de operação do sistema. A relevância dessas informações ocorre à medida que a conduta diária dos usuários frente ao sistema hidráulico interfere, diretamente, na saúde e bem estar dos mesmos. 
Os usuários devem estar cientes de que as ações por eles realizadas em relação à água potável utilizada no chuveiro e lavatório implicam na qualidade da água cinza coletada e, também, indiretamente, na qualidade da água não potável servida, embora esteja previsto um rigoroso controle de qualidade após o tratamento, responsável por liberar ou não a sua utilização. Portanto, ações como urinar no banho, descartar água utilizada na limpeza de piso, de fezes de animais ou de crianças, lavar no lavatório, são práticas inconcebíveis que irão resultar em não conformidade da água não potável com os padrões de qualidade estabelecidos.

Os usuários, ao interferirem na qualidade da água cinza coletada, podem viabilizar a utilização da distribuição de água não potável, porém exigindo ao máximo da estação de tratamento que, obviamente, requer manutenção periódica. Os intervalos entre tais intervenções podem ser reduzidos em função da qualidade da água cinza coletada, a qual depende, diretamente, dos hábitos dos usuários. Estes hábitos repercutem no custo operacional e de manutenção do sistema, mantido pelos próprios proprietários das unidades habitacionais.

O guia de operação deve conter todas as informações essenciais sobre o sistema, redigido em linguagem de fácil entendimento, pormenorizando as atividades críticas, de forma que todos os usuários as interpretem de forma correta. As análises obrigatórias e as respectivas periodicidades para o controle de qualidade da água não potável devem estar contidas no guia, assim como o período de tempo máximo para a manutenção e limpeza da estação de tratamento e dos reservatórios.

\subsubsection{Requisito quantidade}

O requisito quantidade relaciona-se com necessidade em sempre existir água suficiente para abastecer as descargas das bacias sanitárias. Para atendê-lo é necessário aplicar o seguinte critério proposto.

\section{- Previsão da fonte de água potável no reservatório de água não potável}

O volume de água não potável a ser armazenado e distribuído deve ser determinado na fase de projeto, de acordo com o consumo de água das bacias sanitárias e a estimativa do número de utilizações diárias. Logo, a demanda de água está vinculada às necessidades dos usuários. 
A falta de água não potável pode ocorrer quando o volume de efluente tratado é inferior ao demandado pelos equipamentos e, ainda, durante a manutenção da estação de tratamento, situação em que é preciso paralisar o sistema.

A alternativa para suprir a falta de água não potável é utilizar o método tradicional, isto é, a água potável atender a demanda das bacias sanitárias enquanto a estação de tratamento está em manutenção. Isto implica em uma interligação entre o sistema de distribuição de água potável e o de água não potável, o que pode ser realizado entre os reservatórios superiores de armazenamento, com acionamento automático da válvula eletromagnética que libera o fluxo da água potável para o reservatório de água não potável e, de forma alguma, no sentido contrário.

Outra possibilidade é realizar o abastecimento do reservatório inferior de água não potável através de uma ramificação do alimentador predial de água potável. Em ambos os casos há a necessidade de um dispositivo de segurança que evite contaminação da água potável com a água não potável, por exemplo, a separação atmosférica. Cabe ressaltar que a utilização de água potável para atender a demanda das bacias sanitárias elimina a identificação visual, por pigmentação, da água não potável tratada. Esta situação pode gerar desconforto aos usuários, haja vista a possibilidade de entenderem o ocorrido como conexão cruzada dos sistemas.

A Figura 3.5 apresenta, em detalhe, a interligação do alimentador predial de água potável com o reservatório inferior de água não potável. Os cuidados importantes referentes a esta interligação está na possibilidade de mistura de água potável com água não potável tratada e no nível de entrada de água potável no reservatório.

A indicação na Figura 3.5 mostra o local em que deve haver, obrigatoriamente, um dispositivo de segurança que garanta a estanqueidade quando fechado e, quando aberto, o fluxo unidirecional no sentido de abastecer o reservatório inferior de água não potável. A água proveniente da rede pública de abastecimento, sob pressão, demanda a instalação de uma torneira de bóia que impeça a entrada de água no reservatório quando este estiver cheio. Esta entrada de água deve ser instalada em cota superior à lâmina máxima de água não potável, de acordo as recomendações da NBR 5626 (ABNT, 1998) para a separação atmosférica, com o intuito de evitar ou ao menos diminuir a possibilidade de mistura da água não potável tratada com a água potável. 


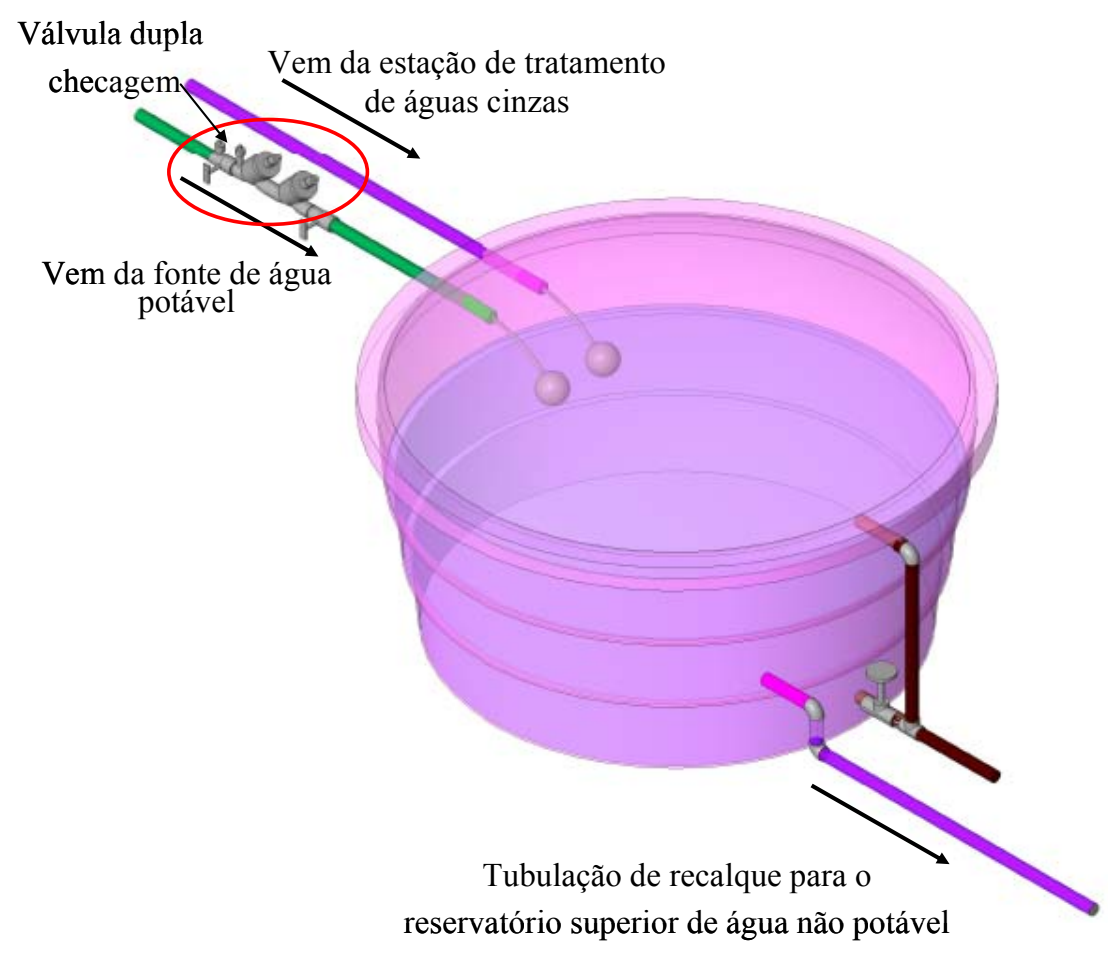

Figura 3.5 - Alternativa da previsão da fonte de água potável, a partir do alimentador predial.

O documento Washington State State Health Department (2004) classifica o reúso de água cinza como atividade que oferece alto risco à saúde dos usuários. A possibilidade de haver patogênicos na água não potável caracteriza um risco iminente de contaminação da rede de água potável local quando houver a interligação dos sistemas. O documento afirma que a garantia da qualidade da água potável requer a separação atmosférica entre o sistema de água potável e o de água não potável, além da instalação obrigatória de uma válvula de segurança que impede o retorno do fluxo quando houver a redução da pressão da rede pública de abastecimento.

A válvula de segurança (Figura 3.6), conforme a publicação da EPA (2007), possui duas válvulas de retenção que funcionam independentemente e liberam o fluxo somente em uma direção. As válvulas entram em operação sob pressões diferentes, o que garante a abertura de uma e, posteriormente, da outra. O mesmo ocorre com o fechamento. No sentido contrário ao fluxo unidirecional projetado, as válvulas não abrem garantindo a não interligação dos sistemas. 


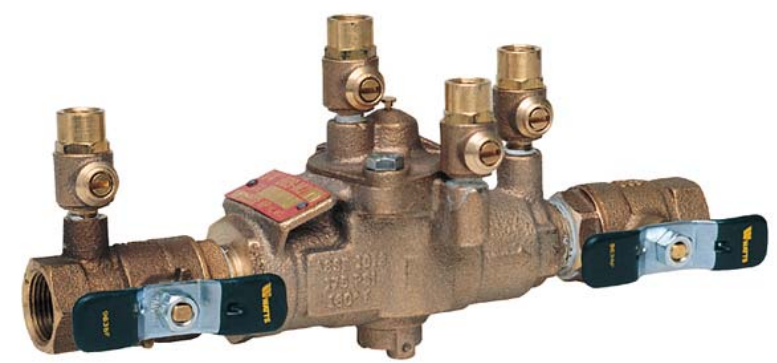

Figura 3.6- Modelo de válvula de retenção dupla com diferencial de pressão (WATTS ${ }^{5}$, 2008).

Estas válvulas de segurança não estão disponíveis no mercado nacional devido à não consolidação da tecnologia no país. Portanto, conceber projetos de distribuição de água não potável em paralelo ao de distribuição de água potável requer a importação destes elementos ver a Fig 3.5, ou, então adotar a separação atmosférica, situação que não proporciona qualquer contato físico entre os subsistemas, conforme estabelecido na NBR 5626 (ABNT, 1998).

A Figura 3.7 apresenta o reservatório com as distâncias mínimas recomendadas pela referida norma técnica. Para obter a separação atmosférica, o ponto de suprimento de água potável deve estar a uma altura "S" do nível da água. Além dessa cota vertical, a tubulação de suprimento também deve possuir uma distância "L mínima", conforme a equação 3.1. A Tabela 3.6 apresenta as distâncias necessárias para obtenção da separação atmosférica no reservatório.

Distância mínima $(\mathrm{L})=3 \mathrm{x}$ diâmetro da tubulação de suprimento

\footnotetext{
5 Watts regulator company - Plumbing, heating and water quality products manufact . Disponível em: http://www.watts.com/default.asp.
} 
Tabela 3.6- Distâncias mínimas recomendas pela NBR 5626 (ABNT; 1998).

\begin{tabular}{|c|c|}
\hline \hline \multicolumn{2}{|c|}{ Altura mínima da separação atmosférica } \\
\hline Diâmetro (d) da tubulação de suprimento em mm & Separação atmosférica mínima (S) em mm \\
\hline $\mathrm{d} \leq 14$ & 20 \\
\hline $14 \leq \mathrm{d} \leq 21$ & 25 \\
\hline $21 \leq \mathrm{d} \leq 41$ & 70 \\
\hline $\mathrm{d}<41$ & $2 \mathrm{~d}$ \\
\hline
\end{tabular}

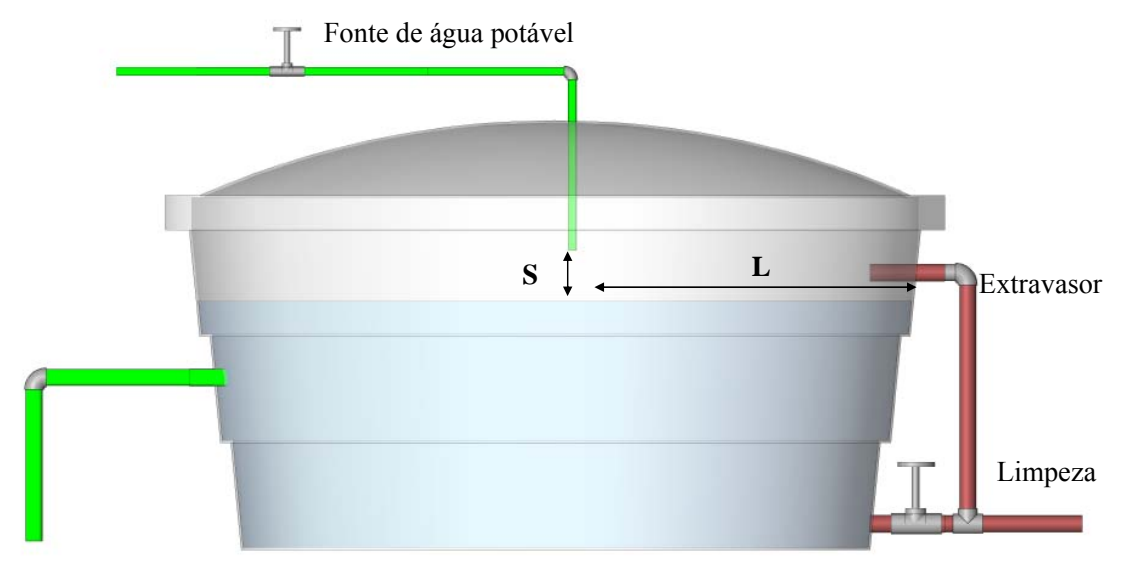

Figura 3.7 - Reservatório considerando a separação atmosférica exigida pela NBR 5626 (ABNT; 1998).

A abordagem dos requisitos e critérios de desempenho envolvidos no sistema de coleta de água cinza, tratamento e distribuição de água não potável evidencia a complexidade do sistema. A implantação desta tecnologia requer a otimização do dimensionamento, a utilização de elementos específicos, serviços operacionais especializados e a orientação educacional dos usuários. Portanto, a tomada de decisão acerca da utilização deste sistema em edifícios residenciais requer extrema cautela, haja vista a iminente possibilidade de contaminação dos usuários quando da ocorrência de qualquer falha. 


\section{O MÉTODO FMEA E SUA APLICACÃO NO SISTEMA PREDIAL DE ÁGUA NÃO POTÁVEL}

Este capítulo apresenta o método de análise de modo e efeito de falha - FMEA, que possibilita a avaliação qualitativa dos requisitos e critérios de desempenho apresentados no capítulo 3. A aplicação desta ferramenta determina o índice de falha para cada requisito de desempenho do sistema de fonte alternativa de água. Além da elaboração do índice de falha para cada requisito, o capítulo também apresenta apenas para o requisito qualidade, o grau de importância das atividades que devem ser implantadas no sistema predial para evitar a falha.

Salienta-se que a aplicação do método da análise de modo e efeito de falha auxilia os envolvidos no sistema, na tomada de decisão dos requisitos propostos.

\subsection{Métodos de análise de riscos}

Risco de projeto é um evento ou condição incerta que, se ocorrer terá um efeito positivo ou negativo sobre pelo menos um, objetivo do trabalho, como tempo, custo, escopo ou qualidade (PMI, 2004).

Com base nas premissas do PMBOK (PMI, 2004) e adaptando para este trabalho, entende-se como risco um efeito negativo e que a sua ocorrência compromete o nível de desempenho desejado para o sistema. Portanto, pode-se afirmar que o sistema de água não potável encontra-se na situação de risco quando os requisitos de desempenho não forem atendidos.

O impacto que o risco causa no sistema, o modo que ele ocorre e como pode ser evitado, são questões que podem ser identificadas com a aplicação de metodologias de análise qualitativa e quantitativa do risco. A utilização dessas análises auxilia o gestor do sistema, na tomada da decisão da ação, de acordo com o efeito causado pelo risco.

A análise de risco abrange atividades de identificação, quantificação, avaliação e gestão do risco. A análise quantitativa fundamenta-se na utilização de dados coletados em entrevistas, opiniões com especialistas, de modo que a sua utilização resulte na obtenção do valor, que represente o risco. Como nesse trabalho não houve a coleta de dados numéricos optou-se em 
realizar a análise qualitativa do risco, obtendo como produto uma noção do impacto causado no sistema pela ocorrência de risco.

\subsection{Análise de risco qualitativa}

As metodologias mais usuais e citadas neste trabalho são Análise preliminar de perigo (APP), Estudo de perigo e operabilidade (HAZOP), Análise de modo e efeito de falha (FMEA) e a Análise de perigo e pontos críticos controláveis (APPCC).

\subsubsection{Análise Preliminar de Perigos (APP)}

A APP é uma técnica qualitativa que consiste na identificação preliminar dos perigos existentes em uma instalação (existente ou em fase de projeto), suas causas, suas conseqüências e uma hierarquização qualitativa dos riscos associados. Além disso, a APP inclui sugestões de medidas para a redução das freqüências e conseqüências dos cenários acidentais (CAMACHO, 2004).

\subsubsection{Análise de perigo e operabilidade (HAZOP)}

A técnica denominada HAZOP tem o objetivo de identificar os perigos e os problemas de operabilidade, isto é, os desvios dos parâmetros de processo, identificando suas causas e conseqüências (CAMACHO, 2004).

O principal objetivo de um Estudo de Perigos e Operabilidade (HAZOP) é investigar de forma minuciosa e metódica cada segmento de um processo (focalizando os pontos específicos do projeto), visando descobrir todos os possíveis desvios das condições normais de operação, identificando as causas de tais desvios e as respectivas conseqüências. Uma vez verificadas as causas e as conseqüências de cada tipo de desvio, esta metodologia procura propor medidas para eliminar ou controlar o perigo ou para sanar o problema de operabilidade da instalação (AGUIAR, 2008).

Ao analisar as duas metodologias percebe-se a semelhança entre elas, diferenciando apenas que a HAZOP analisa o desvio e a sua conseqüência no sistema. Enquanto que a APP analisa o perigo. Pressupondo que o desvio pode acarretar em um perigo, pode-se concluir que a APP é parte da HAZOP. Conforme Aguiar (2008), nem todo desvio é perigo, mas todo perigo é desvio. 


\subsubsection{Análise do perigo do ponto crítico controlável (APPCC)}

A APPCC consiste em outro método da análise qualitativa do risco, também conhecido como HACCP (Hazard analysis critical control point), a ferramenta é fundamentada na identificação dos pontos críticos e controláveis do sistema. Ele foi desenvolvido para ser utilizado em indústrias alimentícias, com o objetivo de manter a qualidade dos alimentos, com características físicas, químicas e biológicas adequadas ao consumo humano.

Com base no modelo aplicado aos alimentos é possível adaptar essa metodologia para o sistema predial de água não potável tendo em vista a necessidade de distribuir água com qualidade adequada aos usuários.

Conforme EPA (2007), no documento "Hazard Analysis Critical Control Point (HACCP) Strategies for Distribution System Monitoring, Hazard Assessment and Control", a ferramenta implantada no sistema de distribuição de água previne ou controla os perigos antes de haver o consumo pelo usuário final e, conseqüentemente, o risco de contaminação.

A ferramenta consiste basicamente em identificar os pontos críticos e desenvolver o modo em que eles podem ser controlados no sistema. Para isso, são estabelecidos limites de controle, que são determinados de acordo com a possibilidade de contaminação do sistema. O controle do ponto crítico é concluído com as especificações de procedimentos de ações corretivas, que devem ser implantadas nas situações em que os limites de controle foram excedidos.

\subsubsection{Análise de modo de falha e efeito (FMEA)}

A FMEA é utilizada para o desenvolvimento e execução do projeto, processo ou serviço, novo ou revisado (PALADY, 2004). A ferramenta tem a função de prevenir a falha antes que ela chegue aos usuários. De um modo geral, o método identifica as falhas, quantifica o risco que o sistema está sujeito devido à sua existência e propõe as respectivas ações de prevenção e correção.

O método baseia-se na hierarquização dos riscos causados pelas falhas e varia em função da importância do efeito desta falha no sistema. A sua aplicação requer duas fases: a investigação e o controle da falha. 
A fase de investigação, apresentada na Tabela 4.1 consiste na identificação da falha que depende, diretamente, da função do projeto, o que varia de acordo com o critério de desempenho. Pautado nestes critérios, determina-se o modo em que o requisito pode falhar e, conseqüentemente, a sua influência no sistema. A conclusão da fase de investigação é obtida pela identificação das causas das falhas.

Tabela 4.1- Modelo de tabela para aplicação da FMEA - Fase investigação.

\begin{tabular}{|c|l|l|l|}
\hline \hline Função & \multicolumn{1}{|c|}{ Modos de falha } & Causa da falha & \multicolumn{1}{c|}{ Efeito da falha } \\
\hline \hline Função do projeto. & $\begin{array}{l}\text { Como o projeto deixa de } \\
\text { desempenhar a função. }\end{array}$ & $\begin{array}{l}\text { Razões que provocam } \\
\text { o modo de falha. }\end{array}$ & $\begin{array}{l}\text { Conseqüência do modo } \\
\text { de falha. }\end{array}$ \\
\hline
\end{tabular}

A Tabela 4.2 considera a avaliação do risco, calculado, para cada causa potencial de falha, baseada na avaliação quantitativa dos itens severidade, ocorrência e detecção. Com base nestes itens é obtido o Nível Prioritário de Risco (NPR). O FMEA, além de quantificar o risco, ainda apresenta ações essenciais e corretivas que visam prevenir e corrigir a ocorrência de falhas, aumentando assim a confiabilidade do sistema.

As atividades consideradas na etapa controle são as ações essenciais e corretivas. Ressalta que as ações essenciais devem ser implantadas no sistema antes do início de sua operação, de modo que não apresente falha durante o seu funcionamento. Enquanto que a ação corretiva é realizada para corrigir a falha pontualmente, ou seja, não evita a sua ocorrência, diferentemente da ação essencial.

Tabela 4.2 - Etapas consideradas na fase controle da ferramenta FMEA.

\begin{tabular}{|c|c|c|c|c|}
\hline Severidade & Ocorrência & Detecção & Risco (NPR) & Ações de controle \\
\hline $\begin{array}{ll}\text { Gravidade } & \text { do } \\
\text { efeito } & \text { do } \\
\text { modo } & \text { de } \\
\text { falha. } & \end{array}$ & $\begin{array}{l}\text { Freqüência do } \\
\text { modo de falha. }\end{array}$ & $\begin{array}{l}\text { Identificação da falha } \\
\text { antes da entrega e } \\
\text { durante a operação do } \\
\text { sistema. }\end{array}$ & $\begin{array}{l}\text { Produto obtido dos } \\
\text { valores atribuídos a } \\
\text { severidade, ocorrência } \\
\text { e pela detecção. }\end{array}$ & $\begin{array}{l}\text { Atividades necessárias } \\
\text { que evitem a } \\
\text { ocorrência do modo de } \\
\text { falha. }\end{array}$ \\
\hline
\end{tabular}

Para complementar a aplicação da ferramenta é preciso especificar e quantificar o risco decorrente da falha. O NPR é obtido a partir do produto dos índices: severidade, ocorrência e detecção da falha, conforme a equação 4.1. 
Os valores atribuídos a cada índice variam de acordo com a classificação da falha analisada, conforme apresentado na Tabela 4.3.

Tabela 4.3 - Valor do item severidade, ocorrência e detecção da falha.

\begin{tabular}{|c|c|c|c|}
\hline \multirow{2}{*}{ ITEM } & \multicolumn{3}{|c|}{ VALOR ATRIBUÍDO } \\
\cline { 2 - 4 } & (1) & (2) & (3) \\
\hline Severidade (S) & Mínima & Moderada & Alta \\
\hline Ocorrência (O) & Remota & Moderada & Pequena \\
\hline Detecção (D) & Grande & Moderada & \\
\hline
\end{tabular}

A abordagem de desempenho é diretamente relacionada com a consideração de requisitos no sistema. Assim, pressupõe-se que ao não considerar um deles haverá uma falha e, conseqüentemente, comprometimento do desempenho desejado. Por esta razão, optou-se por aplicar a ferramenta FMEA no sistema predial de coleta de água cinza e distribuição de água não potável.

A quantificação dos riscos possibilita hierarquizá-los no sistema e, conseqüentemente, auxiliar os envolvidos na fase de projeto, execução e manutenção, na escolha das atividades a serem realizadas.

Cheng et al. (2005) aplicou a ferramenta para analisar o desempenho sistema predial de coleta de esgoto sanitário de acordo com a utilização de diferentes componentes, e concluiu que a ferramenta FMEA é viável e auxilia os projetistas na tomada de decisão.

\subsection{Aplicação da FMEA no sistema predial de água não potável}

A aplicação da ferramenta FMEA no sistema predial de água não potável permite investigar o sistema a fim de identificar todos os componentes e elementos, bem como de ações humanas capazes de interferir no funcionamento do sistema. As etapas de aplicação da FMEA, de acordo com a Figura 4.1, é aplicada para cada requisito e está detalhada nos próximos subitens. 


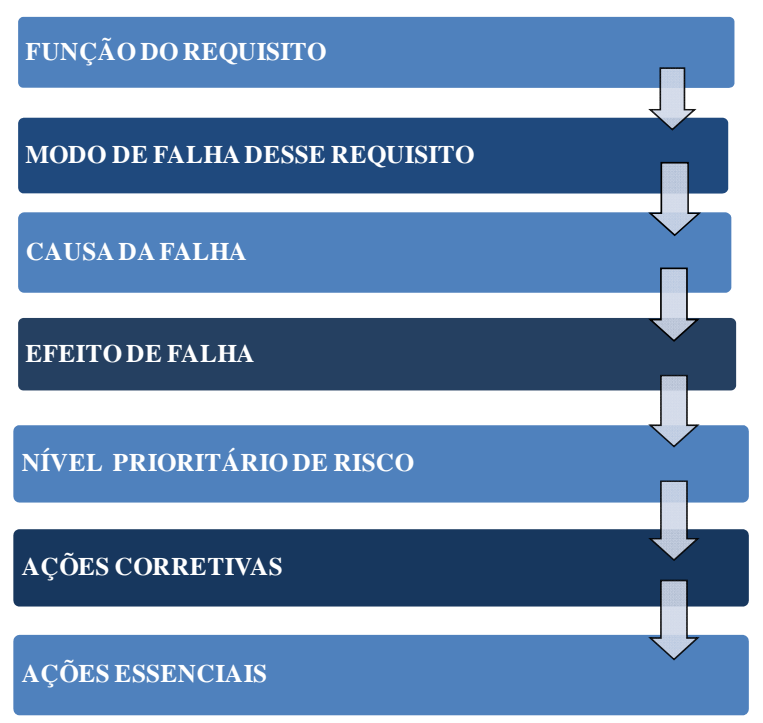

Figura 4.1 - Fluxograma das etapas que compõe a aplicação da FMEA.

\subsubsection{Análise de modo de falha e efeito para o requisito qualidade da água}

A função do projeto de coleta de água cinza, tratamento e distribuição de água não potável é manter a qualidade mínima necessária para atender a demanda, sem expor os usuários aos riscos de saúde. Portanto, o modo de falha deste requisito é a contaminação da água de consumo. Ressalta-se que a contaminação aqui tratada se refere ao não cumprimento dos parâmetros de qualidade, especificados para o sistema de água não potável, o que difere consideravelmente dos padrões de potabilidade da água para consumo.

A especificação do modo de falha está diretamente relacionada com a sua causa e efeito. Tabela 4.4 apresenta as causas das falhas e os respectivos efeitos para o requisito qualidade, fatores indispensáveis para a aplicação da ferramenta FMEA. 
Tabela 4.4 - Causa e efeito de falha para o requisito qualidade da água.

\begin{tabular}{|c|c|c|c|}
\hline \multicolumn{2}{|c|}{ FALHA } & CAUSA & EFEITO \\
\hline \multirow{7}{*}{ 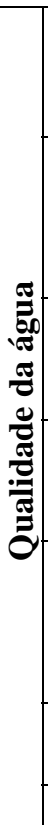 } & 1 & $\begin{array}{l}\text { Interligação inadequada do sistema de água } \\
\text { potável com o sistema de água não potável. }\end{array}$ & $\begin{array}{l}\text { Abastecimento de equipamentos sanitário } \\
\text { com água de qualidade inadequada - } \\
\text { Prejudicar a saúde dos usuários. }\end{array}$ \\
\hline & 2 & $\begin{array}{l}\text { Interligação inadequada do sistema do sistema } \\
\text { de coleta águas cinzas com o sistema de coleta } \\
\text { de águas negras. }\end{array}$ & $\begin{array}{l}\text { Tratamento ineficiente do efluente, tendo em } \\
\text { vista que houve coleta de águas negras e não } \\
\text { apenas das águas cinzas - Prejudicar a saúde } \\
\text { dos usuários. }\end{array}$ \\
\hline & 3 & $\begin{array}{l}\text { Retorno de água não potável no sistema de água } \\
\text { potável. }\end{array}$ & $\begin{array}{l}\text { Contaminação do sistema de água potável e } \\
\text { fornecimento de água não potável para todos } \\
\text { os equipamentos sanitários. }\end{array}$ \\
\hline & 4 & $\begin{array}{l}\text { Vazamento da água de menor qualidade no } \\
\text { sistema predial de água de melhor qualidade. }\end{array}$ & $\begin{array}{l}\text { Infiltração da água de menor qualidade, } \\
\text { proveniente do vazamento, no sistema que } \\
\text { contém água de melhor qualidade. }\end{array}$ \\
\hline & 5 & $\begin{array}{l}\text { Utilização de materiais translúcidos em } \\
\text { reservatórios. }\end{array}$ & $\begin{array}{l}\text { Penetração da luz em reservatório } \\
\text { propiciando o crescimento de algas e } \\
\text { conseqüentemente contaminando a água } \\
\text { armazenada. }\end{array}$ \\
\hline & 6 & Utilização de materiais biodegradáveis. & $\begin{array}{l}\text { Degradação do material e comprometimento } \\
\text { da qualidade da água armazenada. }\end{array}$ \\
\hline & 7 & Inexistência do controle da água não potável. & Colocar em risco a saúde dos usuários. \\
\hline
\end{tabular}

A investigação e análise das falhas fornecem subsídios para se determinar o NPR específico de cada falha que, ao final, resulta no grau de risco global para o requisito qualidade.

A cada falha identificada no sistema é preciso especificar os fatores referentes à severidade, ocorrência e deteç̧ão, tomando-se como base os valores apresentados na Tabela 4.3. A multiplicação destes fatores resulta no NPR específico da falha em questão. A aplicação da ferramenta FMEA a cada falha resulta em análise quantitativa detalhada do sistema, o que permite ao responsável elaborar uma lista de controle, com base nos pontos críticos que requerem especial atenção.

A Tabela 4.5 apresenta a determinação do grau de risco (NPR) referente à cada falha listada na Tabela 4.4, com base nos valores de severidade, ocorrência e detecção de falha apresentados na Tabela 4.3. O somatório dos diferentes graus de risco (NPR) resulta no grau de risco global (NPR $\mathrm{TOTAL})$. 
Tabela 4.5 - Grau de risco, estabelecido pela severidade, ocorrência e detecção de cada falha, e índice de falha parcial e total do requisito qualidade da água e saúde.

\section{REQUISITO QUALIDADE DA ÁGUA}

\begin{tabular}{|c|c|}
\hline EFEITO DA FALHA & GRAU DE RISCO \\
\hline \multirow{3}{*}{$\begin{array}{l}\text { FALHA1 - Abastecimento de } \\
\text { equipamentos sanitários com água de } \\
\text { qualidade inadequada - prejudicar a } \\
\text { saúde dos usuários. }\end{array}$} & $\begin{array}{l}\text { (S)3 - O abastecimento inadequado pode comprometer a saúde } \\
\text { dos usuários, situação considerada de alta severidade. }\end{array}$ \\
\hline & $\begin{array}{l}\text { (O)3 - Essa falha pode ser considerada uma atividade de fácil } \\
\text { ocorrência, tendo em vista que as tubulações possuem } \\
\text { características semelhantes favorecendo a interligação } \\
\text { inadequada. }\end{array}$ \\
\hline & $\begin{array}{l}\text { (D)3 - A difícil detecção é devida a semelhança visual e olfativa } \\
\text { existente entre a água não potável e a potável. }\end{array}$ \\
\hline Prioridade de risco & $\mathrm{NPR}_{\text {Falha } 01}=(\mathrm{S}) 3 \times(0) 3 \times \mathrm{D}(3)=27$ \\
\hline \multirow{3}{*}{$\begin{array}{l}\text { FALHA } 02 \text { - Tratamento ineficiente do } \\
\text { efluente, tendo em vista que houve } \\
\text { coleta de águas negras e não apenas das } \\
\text { águas cinzas - Prejudicar a saúde dos } \\
\text { usuários. }\end{array}$} & $\begin{array}{l}\text { (S)2 - Na existência da conexão cruzada haverá coleta de águas } \\
\text { negras e o sistema de tratamento fará a remoção dos } \\
\text { contaminantes, porém pode ser que não seja tão eficiente. Sendo } \\
\text { assim, considera-se severidade média. }\end{array}$ \\
\hline & $\begin{array}{l}\text { (O)3 - A semelhança entre as tubulações pode favorecer o } \\
\text { cruzamento inadequado, principalmente durante a execução dos } \\
\text { desvios. Podendo ser considerada como falha fácil de ocorrer. }\end{array}$ \\
\hline & $\begin{array}{l}\text { (D)2- Como as águas negras possuem características físicas } \\
\text { diferentes das águas cinzas, devido a grande existência de sólidos } \\
\text { na sua composição pode ser considerada uma falha média de } \\
\text { detecção. }\end{array}$ \\
\hline Prioridade de risco & $\mathrm{NPR}_{\text {Falha } 02}=(\mathrm{S}) 2 \times(\mathrm{O}) 3 \times(\mathrm{D}) 2=12$ \\
\hline \multirow{3}{*}{$\begin{array}{l}\text { FALHA } 03 \text { - Contaminação do sistema } \\
\text { de água potável e fornecimento de água } \\
\text { de não potável para todos os } \\
\text { equipamentos sanitários. }\end{array}$} & $\begin{array}{l}\text { (S)3 - O retorno da água não potável no sistema de água potável } \\
\text { pode ocorrer nos locais em que ocorre a comunicação entre o } \\
\text { sistema. Na sua ocorrência todo o sistema de água potável está } \\
\text { comprometido, atingindo assim alta severidade. }\end{array}$ \\
\hline & $\begin{array}{l}\text { (O)3 - A fácil ocorrência é considerada devido a existência entre } \\
\text { os limites de distâncias mínimos que precisam ser considerados, } \\
\text { durante a previsão da fonte de água potável no reservatório de } \\
\text { água não potável, bem como em manter a pressão hidráulica no } \\
\text { sistema de água potável superior da água não potável. }\end{array}$ \\
\hline & $\begin{array}{l}\text { (D)3 - A difícil detecção é devida à semelhança visual e olfativa } \\
\text { existente entre a água não potável e a potável. }\end{array}$ \\
\hline Prioridade de risco & $\mathrm{NPR}_{\text {Falha } 03}=(\mathrm{S}) 3 \times(0) 3 \times \mathrm{D}(3)=27$ \\
\hline \multirow{3}{*}{$\begin{array}{l}\text { FALHA } 04 \text { - Infiltração da água de } \\
\text { menor qualidade, proveniente do } \\
\text { vazamento, no sistema que contém } \\
\text { água de melhor qualidade. }\end{array}$} & $\begin{array}{l}\text { (S)3 - A contaminação do sistema de água potável com a não } \\
\text { potável compromete a segurança da saúde dos usuários, já que o } \\
\text { sistema de suprimento de água será abastecido com água não } \\
\text { potável. Obtêm-se assim alta severidade na ocorrência da falha. }\end{array}$ \\
\hline & $\begin{array}{l}\text { (O)1 - A infiltração é difícil de ocorrer, para isso a tubulação de } \\
\text { água não potável deve estar danificada. }\end{array}$ \\
\hline & $\begin{array}{l}\text { (D)3 - A difícil detecção é devida a semelhança visual e olfativa } \\
\text { existente entre a água não potável e a potável. }\end{array}$ \\
\hline Prioridade de risco & $\mathrm{NPR}_{\text {Falha 04 }}=(\mathrm{S}) 3 \times(\mathrm{O}) 1 \times(\mathrm{D}) 3=9$ \\
\hline
\end{tabular}


continuação

\section{REQUISITO QUALIDADE DA ÁGUA}

\begin{tabular}{|c|c|}
\hline EFEITO DA FALHA & GRAU DE RISCO \\
\hline \multirow{3}{*}{$\begin{array}{l}\text { FALHA 05 - Penetração da luz em } \\
\text { reservatórios, propiciando } \\
\text { crescimento o de algas } \\
\text { conseqüentemente contaminando a água } \\
\text { armazenada. }\end{array}$} & $\begin{array}{l}\text { (S)2 - A penetração da luz pode influenciar a proliferação de } \\
\text { microorganismos e a estação de tratamento pode ou não ter } \\
\text { eficiência na remoção dos poluentes, assim sendo considera-se a } \\
\text { severidade média. }\end{array}$ \\
\hline & $\begin{array}{l}\text { (O)1 - Fácil de ocorrer, devido a inexistência, de grande } \\
\text { número de produtos em conformidade com a norma t. }\end{array}$ \\
\hline & $\begin{array}{l}\text { (D)3 - A difícil detecção pode ser considerada, em virtude da } \\
\text { impossibilidade visual a olho nu. }\end{array}$ \\
\hline Prioridade de risco & $\mathrm{NPR}_{\text {Falha 05 }}=(\mathrm{S}) 2 \times(\mathrm{O}) 1 \times(\mathrm{D}) 3=6$ \\
\hline \multirow{3}{*}{$\begin{array}{l}\text { FALHA } 06 \text { - Degradação do material e } \\
\text { comprometimento da qualidade da água } \\
\text { armazenada. }\end{array}$} & $\begin{array}{l}\text { (S)2 - Similar à falha } 05 \text {, o sistema de tratamento pode ter } \\
\text { capacidade ou não de remover os poluentes e por isso pode-se } \\
\text { considerar média severidade. }\end{array}$ \\
\hline & $\begin{array}{l}\text { (0)1 - Equivalente à falha } 05 \text {, optou-se por ser fácil de ocorrer, } \\
\text { devido aos poucos produtos certificados no mercado. }\end{array}$ \\
\hline & $\begin{array}{l}\text { (D)3 - Idêntico à falha } 05 \text {, é considerada difícil de detectar, já } \\
\text { que nem sempre identifica-se a não - conformidade do produto a } \\
\text { olho nu. }\end{array}$ \\
\hline Prioridade de risco & $\mathrm{NPR}_{\text {Falha 06 }}=(\mathrm{S}) 2 \times(0) 1 \times(\mathrm{D}) 3=6$ \\
\hline \multirow{3}{*}{$\begin{array}{l}\text { FALHA 07 - Colocar em risco a saúde } \\
\text { dos usuários. }\end{array}$} & $\begin{array}{l}\text { (S)3 - A falta de monitoramento da qualidade da água não } \\
\text { potável pode encaminhar água com condições inadequadas e } \\
\text { conseqüentemente colocar em risco a saúde dos usuários. Desta } \\
\text { forma, a severidade considerada é alta. }\end{array}$ \\
\hline & $\begin{array}{l}(\mathrm{O}) 3 \text { - Por se tratar de mão-de-obra especializada para } \\
\text { monitorar, essa falha pode ser fácil de ocorrer, tendo em vista } \\
\text { que representa um custo a mais para o proprietário. }\end{array}$ \\
\hline & $\begin{array}{l}\text { (D)3- As águas (contaminadas ou não) com aparências } \\
\text { semelhantes não é possível detectar seu grau de contaminação a } \\
\text { olho nu, situação considerada difícil de detectar. }\end{array}$ \\
\hline Prioridade de risco & $N R_{\text {Falha 07 }}=(S) 3 \times(0) 3 \times D(3)=27$ \\
\hline $\begin{array}{c}\text { TOTAL DE FALHA } \\
\text { REQUISITO QUALIDADE }\end{array}$ & $\mathrm{NPR}_{\text {TOTAL }}=(27+12+27+9+6+6+27)=114$ \\
\hline
\end{tabular}

A determinação dos NPR requer a recomendação das medidas de controle para evitar a falha. A Tabela 4.6 apresenta as ações essenciais e corretivas a serem implementadas, de acordo com as respectivas falhas listadas. As ações essenciais se referem àquelas realizadas na fase projeto, operação e manutenção, com o intuito de prevenir futuras falhas. Já as ações corretivas se referem às intervenções no sistema em operação, para sanar falhas já ocorridas. 
Tabela 4.6 - Respectivas ações corretivas e de controle para manter o requisito qualidade da água.

\begin{tabular}{|c|c|c|}
\hline FALHA & AÇÃO ESSENCIAL & AÇÃO CORRETIVA \\
\hline $1,2,3$ e 4 & $\begin{array}{l}\text { a. Utilização de materiais com diferentes características, de } \\
\text { modo que impossibilite a intercambialidade; } \\
\text { b. Pigmentação do efluente tratado; } \\
\text { c. Realização da programação visual do sistema; } \\
\text { d. Identificar o sistema antes da sua execução; } \\
\text { e. Testar o sistema para comprovar a separação das } \\
\text { tubulações; } \\
\text { f. Informar os usuários dos riscos que estão submetidos na } \\
\text { ocorrência de conexão cruzada; } \\
\text { g. Inspeção periódica do sistema executado; } \\
\text { h. Registrar as mudanças/reformas comprovando a } \\
\text { separação das tubulações; } \\
\text { i. Utilização de válvulas que evitam o retorno da água não } \\
\text { potável no sistema de água potável; e da separação } \\
\text { atmosférica; } \\
\text { j. Manter a pressão positiva no sistema de água potável; } \\
\text { k. Realizar vistorias periodicamente para detecção de } \\
\text { vazamentos; } \\
\text { l. Projetar sistemas respeitando o mínimo de separação } \\
\text { entre as tubulações, de modo que na ocorrência do } \\
\text { vazamento, o efluente descartado não comprometa a } \\
\text { segurança do outro sistema; } \\
\text { m. Monitorar periodicamente a qualidade da água tratada, } \\
\text { conforme a Tabela } 3.3 \text { ou } 3.4 \text {. }\end{array}$ & $\begin{array}{l}\text { 1-Interromper o sistema de } \\
\text { distribuição de água não } \\
\text { potável; } \\
\text { 2-Identificar o ponto em que } \\
\text { houve a interligação } \\
\text { inadequada; } \\
\text { 3-Providenciar a separação } \\
\text { entre os sistemas; } \\
\text { 4-Implantar as ações } \\
\text { essenciais. }\end{array}$ \\
\hline 5 & $\begin{array}{l}\text { a. Especificar materiais em conformidade com as normas } \\
\text { técnicas da ABNT. }\end{array}$ & $\begin{array}{l}1 \text { - Retirar o componente; } \\
2 \text {-Realizar a ação essencial. }\end{array}$ \\
\hline 6 & b. Contratar mão-de-obra capacitada para operar o sistema. & $\begin{array}{l}1 \text { - Interromper o sistema. } \\
2 \text { - Realizar a ação essencial. }\end{array}$ \\
\hline 7 & $\begin{array}{l}\text { c. Monitorar periodicamente a qualidade da água tratada, } \\
\text { conforme a Tabela } 3.3 \text { ou } 3.4 \text {. }\end{array}$ & $\begin{array}{l}1 \text { - Implantar sistema de } \\
\text { análises da qualidade da água, } \\
\text { conforme ação essencial. }\end{array}$ \\
\hline
\end{tabular}

\subsubsection{Análise do modo e efeito de falha para o requisito Quantidade}

Este requisito se refere à disponibilidade de fonte alternativa de água para abastecer os equipamentos passíveis de funcionamento com água não potável, ou seja, a descarga da bacia sanitária. O sistema sob estas condições pode apresentar falha por falta de água não potável em volume suficiente para atender a demanda da edificação. A Tabela 4.7 lista as causas do desabastecimento e os conseqüentes efeitos no sistema. 
Tabela 4.7 - Causa e efeito de falha para o requisito quantidade.

\begin{tabular}{|c|c|c|}
\hline FALHA & CAUSA & EFEITO \\
\hline 1 & $\begin{array}{l}\text { O volume tratado de efluente é inferior ao } \\
\text { demandado nas descargas das bacias } \\
\text { sanitárias. }\end{array}$ & \multirow[t]{2}{*}{$\begin{array}{l}\text { Falta de água nas descargas das bacias } \\
\text { sanitárias. }\end{array}$} \\
\hline 2 & $\begin{array}{l}\text { Período de manutenção da estação de } \\
\text { tratamento. }\end{array}$ & \\
\hline 3 & $\begin{array}{l}\text { Coleta e tratamento de maior volume de } \\
\text { efluente do que o necessário. }\end{array}$ & $\begin{array}{l}\text { Superdimensionamento das estações de } \\
\text { tratamento, necessitando de maiores áreas } \\
\text { para instalação. }\end{array}$ \\
\hline
\end{tabular}

A determinação do NPR está atrelada à severidade, ocorrência e facilidade de detecção da falha. Os valores atribuídos a cada um destes itens, referentes às diferentes falhas estão

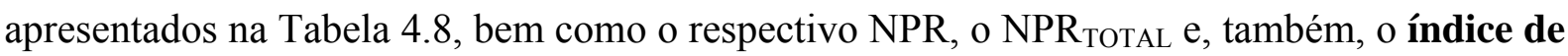
falha do requisito quantidade.

Tabela 4.8 - Grau de risco estabelecido pela severidade, ocorrência e detecção de cada falha e índice de falha parcial e total do requisito quantidade.

\begin{tabular}{|c|c|}
\hline \multicolumn{2}{|c|}{ REQUISITO QUANTIDADE } \\
\hline EFEITO DA FALHA & GRAU DE RISCO \\
\hline \multirow{3}{*}{$\begin{array}{l}\text { FALHA } 01 \text { - Falta de água devido a coleta } \\
\text { de menor volume do que o necessário. }\end{array}$} & $\begin{array}{l}\text { (S)3 - A falta de água não potável corresponde a alta } \\
\text { severidade na falha, tendo em vista a inviabilização da bacia } \\
\text { sanitária. }\end{array}$ \\
\hline & $\begin{array}{l}\text { (O)2 - A falha consiste numa atividade de probabilidade média } \\
\text { de ocorrer, pois geralmente o volume de efluente do lavatório e } \\
\text { chuveiro é bem superior ao demandado pelas descargas das } \\
\text { bacias sanitárias. }\end{array}$ \\
\hline & $\begin{array}{l}\text { (D)1 - Pode-se considerar de fácil detecção, pois não haverá } \\
\text { água nas descargas das bacias. }\end{array}$ \\
\hline Prioridade de risco & $\mathrm{NPR}_{\text {Falha 01 }}=(\mathrm{S}) 3 \times(\mathrm{O}) 2 \times(\mathrm{D}) 1=6$ \\
\hline \multirow{3}{*}{$\begin{array}{l}\text { FALHA } 02 \text { - Falta de água devido as } \\
\text { atividades de manutenção da estação de } \\
\text { tratamento. }\end{array}$} & $\begin{array}{l}\text { (S)3 - A falta de água não potável corresponde a alta } \\
\text { severidade na falha. Tendo em vista que inviabiliza a utilização } \\
\text { da bacia sanitária. }\end{array}$ \\
\hline & $\begin{array}{l}\text { (O)1 - Difícil de ocorrer, pois geralmente a manutenção é } \\
\text { programada. }\end{array}$ \\
\hline & $\begin{array}{l}\text { (D)1 - Pode-se considerar de fácil detecção, pois não haverá } \\
\text { água nas descargas das bacias. }\end{array}$ \\
\hline Prioridade de risco & $\mathrm{NPR}_{\text {Falha } 02}=(\mathrm{S}) 3 \times(0) 1 \times(\mathrm{D}) 1=3$ \\
\hline \multirow{3}{*}{$\begin{array}{l}\text { FALHA } 03 \text { - Superdimensionamento das } \\
\text { estações de tratamento, necessitando de } \\
\text { maiores áreas para instalação, aumentando } \\
\text { a viabilidade técnica e econômica. }\end{array}$} & $\begin{array}{l}\text { (S)3 - O custo da estação é proporcional à vazão de efluente de } \\
\text { entrada, o que implica alta severidade nessa falha. }\end{array}$ \\
\hline & $\begin{array}{l}\text { (O)3 - A compatibilização do volume demandado x ofertado é } \\
\text { considerada difícil tarefa tendo em vista a falta de dados } \\
\text { disponíveis para a determinação do volume correto. Por isso, } \\
\text { esta falha é fácil de ocorrer. }\end{array}$ \\
\hline & $\begin{array}{l}\text { (D)1 - A partir do projeto já é possível verificar o } \\
\text { superdimensionamento. O que resulta na fácil detecção. }\end{array}$ \\
\hline Prioridade de risco & $\mathrm{NPR}_{\text {Falha } 03}=(\mathrm{S}) 3 \times(\mathrm{O}) 3 \times(\mathrm{D}) 1=9$ \\
\hline $\begin{array}{c}\text { TOTAL DE FALHA } \\
\text { REQUISITO QUANTIDADE }\end{array}$ & NPRTOTAL $=(6+3+9)=18$ \\
\hline
\end{tabular}


As ações essenciais que previnem a ocorrência das falhas, bem como as ações corretivas são apresentadas na Tabela 4.9.

Tabela 4.9 - As ações corretivas e de controle para manter o requisito quantidade da água

\begin{tabular}{|c|l|lc|}
\hline FALHA & \multicolumn{1}{|c|}{ AÇÃO ESSENCIAL } & AÇÃO CORRETIVA \\
\hline 1 e 2 & $\begin{array}{l}\text { Implantar no projeto a opção de comunicação entre } \\
\text { reservatórios de água potável e não potável, ou a partir do } \\
\text { hidrômetro. Respeitando os limites propostos no texto. }\end{array}$ & $\begin{array}{l}\text { 1-Realizar } \\
\text { essencial. }\end{array}$ & ação \\
\hline 3 & $\begin{array}{l}\text { Dimensionar a ETAC de acordo com a demanda das bacias } \\
\text { sanitárias; }\end{array}$ & $\begin{array}{l}\text { 1-Redimensionar } \\
\text { sistema. }\end{array}$ & o \\
\hline
\end{tabular}

\subsubsection{Análise do modo e efeito de falha para o requisito conforto}

$\mathrm{O}$ requisito conforto considerado neste trabalho refere-se à disponibilidade, acessibilidade e adequabilidade, apresentados no capítulo 3 para o sistema predial de coleta de água cinza.

O conforto dos usuários é prejudicado pelo mal estar a ele provocado, seja pelo mau cheiro no ambiente ou pela atividade de difícil execução como, por exemplo, a desobstrução da tubulação de coleta de esgoto. Este mal estar pode ser evitado a partir da aplicação dos critérios para este requisito. A Tabela 4.10 apresenta as falhas referentes a este requisito, abordando a sua causa e o efeito no sistema.

Tabela 4.10 - Causa e efeito de falha para o requisito conforto.

\begin{tabular}{|c|l|l|}
\hline FALHA & \multicolumn{1}{|c|}{ CAUSA } & \multicolumn{1}{|c|}{ EFEITO } \\
\hline $\mathbf{1}$ & Armazenamento de efluente indesejado. & $\begin{array}{l}\text { Gera mau cheiro e prolifera vetores no } \\
\text { ambiente. }\end{array}$ \\
\hline $\mathbf{2}$ & $\begin{array}{l}\text { Falta de acesso na tubulação de coleta de } \\
\text { efluentes. }\end{array}$ & $\begin{array}{l}\text { Danificação da tubulação para identificar o } \\
\text { local da obstrução. }\end{array}$ \\
\hline $\mathbf{3}$ & Subdimensionamento da tubulação. & $\begin{array}{l}\text { Comprometimento do arraste do efluente no } \\
\text { interior da tubulação, ocasionando a obstrução. }\end{array}$ \\
\hline $\mathbf{4}$ & $\begin{array}{l}\text { Ausência de extravasor no reservatório de } \\
\text { coleta de efluentes. }\end{array}$ & $\begin{array}{l}\text { Transbordamento do efluente no meio } \\
\text { ambiente. }\end{array}$ \\
\hline $\mathbf{5}$ & $\begin{array}{l}\text { Ausência da válvula de gaveta para realizar a } \\
\text { limpeza no reservatório de coleta. }\end{array}$ & Dificuldade na remoção do efluente indesejado. \\
\hline
\end{tabular}

Apresentadas as causas e os efeitos da falha, pretende-se determinar o NPR de cada falha apresentada. Para isso é necessário determinar a severidade, a ocorrência e a detecção e, 
assim, obter o produto para determinar o índice de falha desse requisito. A Tabela 4.11 apresenta os respectivos índices.

Tabela 4.11 - Grau de risco, estabelecido pela severidade, ocorrência e detecção de cada falha, e índice de falha parcial e total do requisito conforto.

\begin{tabular}{|c|c|}
\hline \multicolumn{2}{|c|}{ REQUISITO CONFORTO } \\
\hline EFEITO DA FALHA & GRAU DE RISCO \\
\hline \multirow{3}{*}{$\begin{array}{l}\text { FALHA } 01 \text { - Gera mau cheiro e prolifera } \\
\text { vetores no ambiente. }\end{array}$} & $\begin{array}{l}\text { (S)3 - A água cinza armazenada mais de } 24 \text { horas pode acarretar } \\
\text { no início de atividades bacteriológicas e conseqüentemente mau } \\
\text { cheiro no ambiente. Tal situação é considerada de alta } \\
\text { severidade. }\end{array}$ \\
\hline & $\begin{array}{l}(\mathbf{O}) 3 \text { - Caso não seja previsto o dispositivo de modo adequado o } \\
\text { mau cheiro ocorrerá de modo fácil e será necessário um sistema } \\
\text { de esgotamento no local por algum meio de transporte. }\end{array}$ \\
\hline & $\begin{array}{l}\text { (D)2 - Por ser detectado quando houver mau cheiro, pode ser } \\
\text { considerada média facilidade de detecção. }\end{array}$ \\
\hline Prioridade de risco & NPR $_{\text {Fallha 01 }}=(S) 3 \times(O) 3 \times(D) 2=18$ \\
\hline \multirow{3}{*}{$\begin{array}{l}\text { FALHA 02- Danificação da tubulação } \\
\text { para identificar o local da obstrução. }\end{array}$} & $\begin{array}{l}\text { (S)2 - A falta de acesso na tubulação é considerada falha de } \\
\text { média severidade, já que pode haver desobstrução, porém com } \\
\text { danificação do material. }\end{array}$ \\
\hline & $\begin{array}{l}\mathbf{( O ) 2} \text { - Pelo efluente produzido pelas águas cinzas possuir menos } \\
\text { sólidos na sua composição quando comparado com o esgoto } \\
\text { bruto, pode-se considerar uma falha com índice médio de } \\
\text { ocorrer. }\end{array}$ \\
\hline & $\begin{array}{l}\text { (D)3- A falha é difícil de ser detectatada, já que não existe local } \\
\text { para inspeção. }\end{array}$ \\
\hline Prioridade de risco & $\mathrm{NPR}_{\text {Falha 02 }}=(\mathrm{S}) 2 \times(\mathrm{O}) 2 \times \mathrm{D}(3)=12$ \\
\hline \multirow{3}{*}{$\begin{array}{l}\text { FALHA 03- Comprometimento do } \\
\text { escoamento do efluente no interior da } \\
\text { tubulação, ocasionando a obstrução. }\end{array}$} & $\begin{array}{l}\text { (S)3 - Para esse caso, a falha é de alta severidade, tendo em } \\
\text { vista o entupimento, retorno do efluente na tubulação e } \\
\text { conseqüentemente o desconforto dos usuários. }\end{array}$ \\
\hline & $\begin{array}{l}\text { (O)3 - Considera-se uma falha fácil de ocorrer. Como o sistema } \\
\text { é dimensionado a partir dos chuveiros e lavatórios, pode-se } \\
\text { conceber erroneamente projeto com tubos de pequeno diâmetro. } \\
\text { Os projetistas não se atentam que a probabilidade de uso } \\
\text { simultâneo do chuveiro é alta o que implica em projetar tubo de } \\
\text { queda com maior diâmetro. }\end{array}$ \\
\hline & $\begin{array}{l}\text { (D)3 - A difícil deteção causada pela impossibilidade de } \\
\text { detectar a falha antes do desconforto e não ser uma tarefa visível } \\
\text { a olho nu. }\end{array}$ \\
\hline Prioridade de risco & $\mathrm{NPR}_{\text {Falha 03 }}=(\mathrm{S}) 3 \times(\mathrm{O}) 3 \times \mathrm{D}(3)=27$ \\
\hline \multirow{3}{*}{$\begin{array}{l}\text { FALHA } 04-\text { Transbordamento do } \\
\text { efluente no meio ambiente. }\end{array}$} & $\begin{array}{l}\text { (S)3 - A ocorrência do transbordamento na área é considerada } \\
\text { falha de alta severidade, tendo em vista que pode iniciar mau } \\
\text { cheiro no ambiente. }\end{array}$ \\
\hline & $\begin{array}{l}\text { (O)3 - Caso o extravasor não seja adequadamente dimensionado } \\
\text { a falha é fácil de ocorrer. }\end{array}$ \\
\hline & (D)1 - Por ser uma falha visível, é considerada de fácil detecção. \\
\hline Prioridade de risco & $\mathrm{NPR}_{\text {Falha } 04}=(\mathrm{S}) 3 \times(\mathrm{O}) 3 \times \mathrm{D}(1)=9$ \\
\hline
\end{tabular}




\section{REQUISITO CONFORTO}

EFEITO DA FALHA

FALHA 05-Dificuldade na remoção do efluente indesejado.
GRAU DE RISCO

(S)2 - A severidade é média, tendo em vista que o sistema pode ser esgotado por meio de caminhão pipa. Consiste numa situação mais dispendiosa, porém possível.

(O)2 - A maioria dos projetistas já concebe esse dispositivo de limpeza, assim sendo considera-se falha com probabilidade média de ocorrer.

(D)1 - A partir da análise do projeto é possível detectar. Por isso, pode-se afirmar que consiste em uma falha de fácil detecção.

As ações corretivas e essenciais necessárias para implantar nesse requisito de modo a evitar a falha encontram-se na Tabela 4.12.

Tabela 4.12 - Respectivas ações corretivas e de controle para manter o requisito conforto.

\begin{tabular}{|c|c|c|}
\hline FALHA & AÇÃO ESSENCIAL & AÇÃO CORRETIVA \\
\hline $1,2,4$ e 5 & $\begin{array}{l}\text { FALHA } 01 \text { - Utilizar dispositivo apropriado para o sistema de } \\
\text { esgoto com a função de descartar o efluente na rede de esgoto } \\
\text { antes da estação de tratamento quando necessário. } \\
\text { FALHA } 02 \text { - Instalar materiais que possibilite acesso na } \\
\text { tubulação de esgoto para inspeção a cada } 15 \mathrm{~m} \text {, caso exista } \\
\text { curva de } 90^{\circ} \text { a inspeção deve ser após } 1,5 \mathrm{~m} \text {. } \\
\text { FALHA } 03 \text { - Possuir diâmetro interno na tubulacão no }\end{array}$ & $\begin{array}{l}1 \text { - Interromper o sistema de } \\
\text { distribuição de água não } \\
\text { potável; } \\
2 \text { - Realizar a ação essencial. }\end{array}$ \\
\hline 3 & $\begin{array}{l}\text { mínimo de } 75 \text { mm. } \\
\text { FALHA } 04 \text { - Considerar em projeto as recomendações da } \\
\text { NBR } 5626 \text { (ABNT, 1998). } \\
\text { FALHA 05 - Considerar em projeto as recomendações da } \\
\text { NBR } 5626 \text { (ABNT, 1998). }\end{array}$ & $\begin{array}{l}1 \text { - Redimensionar a tubulação; } \\
2 \text { - Substituir pela que possui } \\
\text { capacidade de arraste. }\end{array}$ \\
\hline
\end{tabular}

TOTAL DE AÇÕES ESSENCIAIS DO REQUISITO CONFORTO = 5

\subsubsection{Tabulação do nível prioritário de risco (NPR) de cada requisito}

A Tabela 4.13 lista as falhas de cada requisito e seu respectivo nível prioritário de risco. A hierarquização da importância das falhas é associada aos riscos calculados, que são influenciados pela severidade (s), ocorrência (o) e detecção (d). Existem falhas que possuem o 
mesmo grau de risco e, para a sua hierarquização, é considerada, em primeiro lugar, a que possui a severidade mais alta seguida da facilidade de detecção e, por último, da ocorrência.

Tabela 4.13 - Tabulação dos NPR de cada requisito apresentado.

\begin{tabular}{|c|c|c|c|c|}
\hline FALHA & NPR & $\mathbf{S}$ & $\mathbf{O}$ & D \\
\hline \multicolumn{4}{|c|}{ REQUISITO QUALIDADE } & \\
\hline Falha 01 & 27 & 3 & 3 & 3 \\
\hline Falha 02 & 12 & 2 & 3 & 2 \\
\hline Falha 03 & 27 & 3 & 3 & 3 \\
\hline Falha 04 & 9 & 3 & 1 & 3 \\
\hline Falha 05 & 6 & 2 & 1 & 3 \\
\hline Falha 06 & 9 & 2 & 1 & 3 \\
\hline Falha 07 & 27 & 3 & 3 & 3 \\
\hline TOTAL & 114 & & & \\
\hline \multicolumn{5}{|c|}{$\begin{array}{l}\text { ORDEM DE PRIORIDADE: Falha 01, 03, } 07 \text { e } 02 \text { são consideradas as mais importantes, tendo em } \\
\text { vista a alta severidade que elas representam no sistema. }\end{array}$} \\
\hline \multicolumn{5}{|c|}{ REQUISITO QUANTIDADE } \\
\hline Falha 01 & 6 & 3 & 2 & 1 \\
\hline Falha 02 & 3 & 3 & 1 & 1 \\
\hline Falha 03 & 9 & 3 & 3 & 1 \\
\hline TOTAL & 18 & & & \\
\hline
\end{tabular}

ORDEM DE PRIORIDADE: Falha 03, 01 e 02 são consideradas as mais importantes, tendo em vista a alta severidade que elas representam no sistema

\begin{tabular}{|c|c|c|c|c|}
\hline \hline REQUISITO CONFORTO & 3 & 3 & 2 \\
\hline \hline Falha 01 & 18 & 2 & 2 & 3 \\
\hline Falha 02 & 12 & 3 & 3 & 3 \\
\hline Falha 03 & 27 & 3 & 3 & 1 \\
\hline Falha 04 & 9 & 2 & 2 & 1 \\
\hline Falha 05 & 4 & & & \\
\hline TOTAL & $\mathbf{7 0}$ & & & \\
\hline
\end{tabular}

ORDEM DE PRIORIDADE: Falha 03, 01 e 02 são consideradas as mais importantes, tendo em vista a alta severidade que elas representam no sistema.

As falhas enumeradas 01, 03 e 07 possuem o máximo número prioritário de risco sendo, portanto, consideradas importantes na mesma intensidade para o requisito qualidade. Elas estão relacionadas com o risco de distribuir água com qualidade inferior à necessária nos 
equipamentos sanitários. Tal situação pode ocorrer pela conexão cruzada entre os sistemas de água potável com não potável ou pela inexistência do controle de qualidade da água tratada.

O requisito quantidade possui maior grau prioritário de risco para a falha $\mathrm{n}^{\mathrm{o}} 3$, que consiste na coleta e tratamento de maior quantidade de efluente do que a necessária, acarretando em projeção de maiores estações de tratamento e conseqüentemente, desperdício de água tratada. E para finalizar, o requisito conforto possui a falha $\mathrm{n}^{\mathrm{o}} 3$ como a mais grave, tendo em vista que a tubulação de menor diâmetro pode provocar vários inconvenientes como, por exemplo, o comprometimento da autolimpeza da tubulação.

A determinação do Nível Prioritário de Risco (NPR) ao englobar a severidade, a ocorrência e a facilidade de detecção, não faz distinção de grau de importância em relação a cada requisito apresentado: qualidade, quantidade e conforto do sistema.

Neste trabalho considera-se que as falhas relacionadas com o requisito qualidade são mais importantes do que as dos outros. Essa consideração justifica-se porque seus pontos críticos requerem maior atenção para não expor os usuários aos riscos que prejudiquem a sua saúde.

O posicionamento do Comitê Brasileiro de Sustentabilidade do Ambiente Construído (CBCS), mostra grande preocupação relacionada ao requisito qualidade. A comprovação da preocupação para esse requisito se dá com algumas questões abordadas, tais como: a identificação dos pontos críticos, aptos a comprometer a segurança do sistema; a capacitação dos projetistas de sistemas prediais; carência de normas sobre o tema, utilização de tubulações diferenciadas para o sistema de água não potável.

A hierarquização proposta para os requisitos é apresentada na Figura 4.2. Os respectivos graus de importância atribuídos aos diferentes requisitos classificam os riscos referentes à qualidade como os mais importantes do sistema e, os riscos relacionados ao conforto, de menor preocupação. 


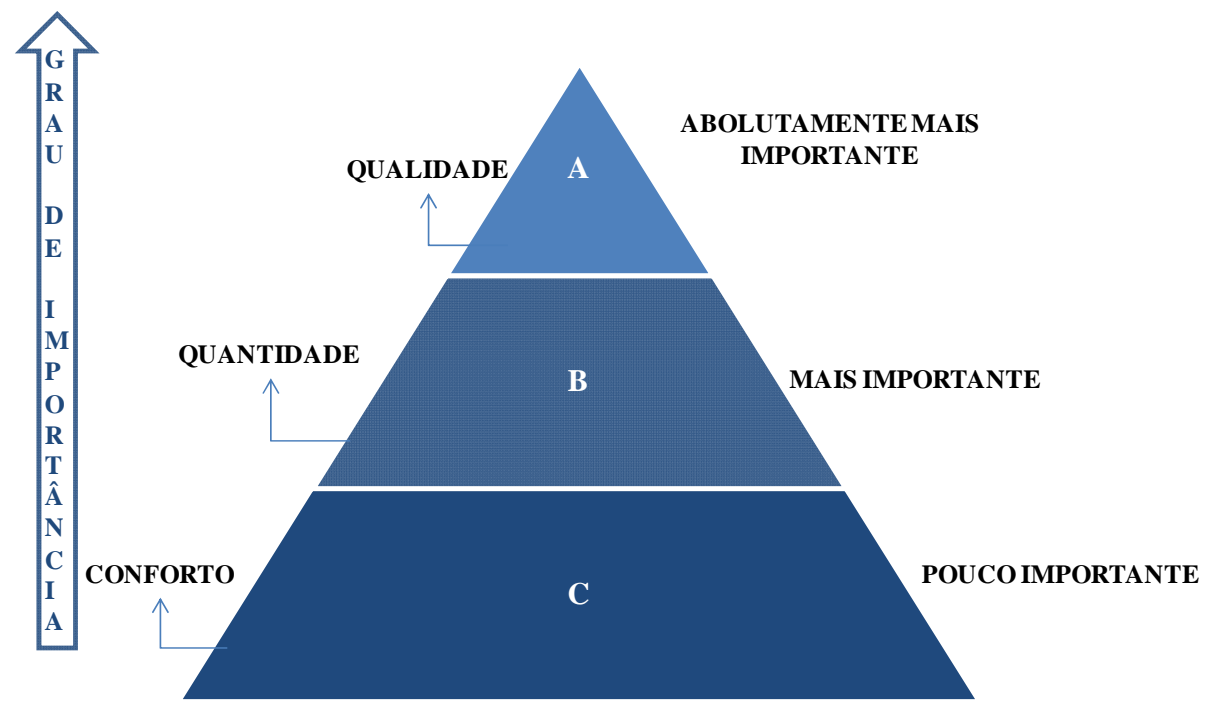

Figura 4.2 - Graus de importância aplicados a cada requisito.

De fato, o requisito qualidade é mais importante que a quantidade de água que, por sua vez, mostra-se mais importante que o conforto. A hierarquização dos requisitos não significa dizer que os de menor importância devam ser desconsiderados, pois a não conformidade de qualquer item insere uma falha que, por menor que seja, diminui o desempenho global do sistema.

\subsection{Hierarquização das atividades essenciais do requisito QUALIDADE}

O requisito qualidade é considerado nesse trabalho como o mais importante dentre os selecionados e, por isto, estabeleceu-se os graus de importância para cada atividade essencial desse requisito, apresentadas na Tabela 4.14, considerando as fases de projeto, execução e manutenção.

A justificativa desta escolha deve-se à necessidade de prevenir e controlar os riscos de contaminação da água distribuída aos equipamentos sanitários. As atividades essenciais para esse requisito são classificadas de acordo com a importância, sendo que assume valor 1 para pouco importante até o valor 5 para absolutamente importante. A Tabela 4.14 apresenta a escala de importância considerada no texto. 
Tabela 4.14 - Classificação dos graus de importância considerado nas ações essenciais.

\begin{tabular}{|c|c|}
\hline \hline GI* & Intensidade \\
\hline 1 & Pouco importante \\
\hline 2 & Importante \\
\hline 3 & Mais importante \\
\hline 4 & Muito mais importante \\
\hline 5 & Absolutamente mais importante \\
\hline
\end{tabular}

*GI corresponde ao grau de importância.

Cabe ressaltar que todas as atividades de controle são consideradas importantes ao projetar o sistema de água não potável. Algumas são classificadas mais importantes do que outras devido a sua aplicação proporcionar maior segurança à saúde dos usuários.

Além do grau de importância associado a cada atividade essencial, serão considerados os índices de fase - valores associados às fases de projeto, execução e manutenção. Propõe-se que a fase projeto seja mais importante do que a etapa execução e manutenção, respectivamente.

A viabilização do grau hierárquico de importância requer que o sistema seja executado minuciosamente de acordo com as prescrições contidas no projeto, obrigando o acompanhamento especializado para evitar qualquer modificação durante a instalação e operação do sistema.

Respeitando essas premissas, são utilizados os índices de fase com valores 9, 6 e $\mathbf{1}$ para as atividades especificadas para a fase de projeto, execução e manutenção, respectivamente. Assim, o valor da ação no requisito é obtido pelo produto do grau de importância de cada ação essencial com o índice de fase, relacionado com as etapas do sistema, de acordo com a equação 4.2 .

Valor da ação $=$ Grau de importância $x$ índice da fase

A Tabela 4.15 apresenta os valores de importância de cada ação essencial do requisito qualidade, de acordo com a equação 4.2. Para cada fase do sistema é associada uma letra: "P" representa a etapa do projeto, "E", a execução, e "M", a manutenção. O valor da ação 
apresentado na Tabela 4.15 é obtido pelo produto do grau de importância, conforme a Tabela 4.14, e o índice de fase: projeto, execução e manutenção.

Tabela 4.15 - Valores das ações essenciais nas fases projeto (P), execução (E) e manutenção (M) do requisito qualidade.

\begin{tabular}{|c|c|c|c|c|}
\hline Ações essenciais & Fase & GI* & $\begin{array}{l}\text { Índice } \\
\text { da } \\
\text { fase }^{* *}\end{array}$ & $\begin{array}{l}\text { Valor da } \\
\text { ação }\end{array}$ \\
\hline $\begin{array}{l}\text { - Instalar válvulas que evitem o retorno da água não potável ou } \\
\text { considerar a separação atmosférica entre os sistemas de água potável } \\
\text { e não potável. }\end{array}$ & $\mathbf{P}$ & 5 & 9 & 45 \\
\hline $\begin{array}{l}\text { - Utilizar materiais e componentes com diferentes características, de } \\
\text { modo que impossibilite a sua intercambialidade. }\end{array}$ & $\mathbf{P}$ & 4 & 9 & 36 \\
\hline - Manter a pressão positiva no sistema de água potável. & $\mathbf{P}$ & 3 & 9 & 27 \\
\hline $\begin{array}{l}\text { - Projetar sistemas respeitando o distanciamento das tubulações, de } \\
\text { modo que na ocorrência do vazamento, o efluente descartado não } \\
\text { comprometa a segurança do outro sistema. }\end{array}$ & $\mathbf{P}$ & 2 & 9 & 18 \\
\hline \multicolumn{5}{|c|}{ TOTAL FASE PROJETO = 12} \\
\hline - Capacitar a mão-de-obra. & $\mathbf{E}$ & 3 & 6 & 18 \\
\hline - Identificar as tubulações antes da execução. & $\mathbf{E}$ & 3 & 6 & 18 \\
\hline \multicolumn{5}{|c|}{ TOTAL FASE EXECUÇÃO = 36} \\
\hline $\begin{array}{l}\text { - Contratar mão-de-obra especializada para operar a estação de } \\
\text { tratamento. }\end{array}$ & $\mathbf{M}$ & 5 & 6 & 30 \\
\hline $\begin{array}{l}\text { - Registrar as reformas em livro de ocorrência de manutenção do } \\
\text { edifício nas tubulações e comprovar inexistência de conexão cruzada. }\end{array}$ & $\mathbf{M}$ & 3 & 1 & 3 \\
\hline - Realizar a pigmentação diária do efluente tratado. & $\mathbf{M}$ & 3 & 1 & 3 \\
\hline - Educar a população, abordando a importância da qualidade da água. & $\mathbf{M}$ & 3 & 1 & 3 \\
\hline - Pintar a tubulação anualmente. & $\mathbf{M}$ & 2 & 1 & 2 \\
\hline $\begin{array}{l}\text { - Realizar teste na tubulação mensalmente, para verificação da } \\
\text { conexão cruzada. }\end{array}$ & $\mathbf{M}$ & 3 & 1 & 3 \\
\hline - Inspeção visual mensal da separação da tubulação. & $\mathbf{M}$ & 2 & 1 & 2 \\
\hline - Realizar vistorias mensalmente para detecção de vazamentos. & $\mathbf{M}$ & 2 & 1 & 2 \\
\hline $\begin{array}{l}\text { - Monitorar periodicamente a qualidade da água tratada, conforme a } \\
\text { tabela } 3.3 \text { ou } 3.4 \text {. }\end{array}$ & $\mathbf{M}$ & 5 & 1 & 5 \\
\hline
\end{tabular}

* GI corresponde ao grau de importância para cada ação essencial no sistema, varia de 1 a 5 , conforme a Tabela 4.14.

** Valor estabelecido para fase projeto (9), execução (6) e manutenção (1).

A partir da Tabela 4.15, é possível hierarquizar as atividades de controle para o sistema predial de água não potável, subsidiando projetistas, executores e operadores do sistema na tomada de decisão a cerca das atividades a serem realizadas. 
A realização das atividades listadas Tabela 4.15 minimiza a possibilidade de falha e, em conseqüência, maximiza o desempenho do sistema de água não potável. A não preocupação com qualquer uma das atividades aumenta a probabilidade de falha e a exposição dos usuários aos riscos de contaminação.

A Figura 4.3 ilustra o sistema predial de água não potável no edifício residencial. Os locais identificados correspondem aos considerados críticos, ou seja, aqueles mais prováveis de ocorrência de conexão cruzada, o que resulta em contaminação da água potável e não potável.

Cada ponto crítico identificado na Figura 4.3 corresponde a uma possibilidade de contaminação que pode ocorrer durante:

1. a previsão da fonte de água potável no reservatório de água não potável;

2. a execução das colunas de água potável com não potável;

3. a previsão da fonte de água potável no reservatório superior de água não potável;

4. a execução do barrilete dos sistemas de água potável e não potável;

5. a execução dos ramais de distribuição de água potável e não potável;

6. a execução dos tubos de queda de águas cinzas e negras;

7. a execução da ligação ramal de esgoto com tubo de queda de águas cinzas e negras;

8. a execução dos coletores de águas cinzas e negras. 


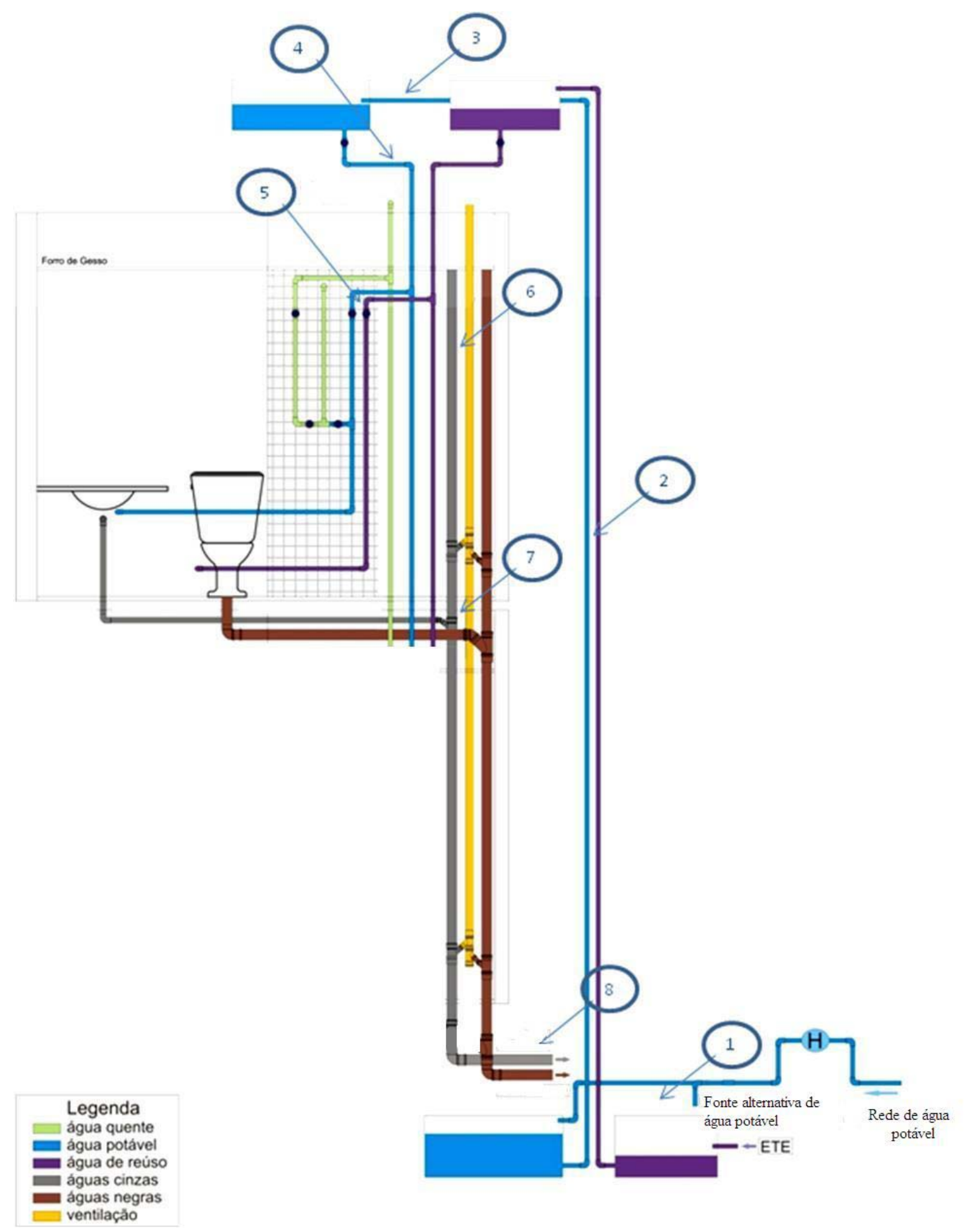

Figura 4.3 - Visualização dos pontos de controle do sistema predial de água não potável.

Desta forma, a implantação do sistema de água não potável em edifício residencial, implica a adoção de medidas de segurança para não colocar em risco a saúde dos usuários. Estas 
medidas estão relacionadas com a concepção do projeto, com o treinamento da mão-de-obra que executa e com a que faz a gestão do sistema.

A educação do usuário também consiste em uma atividade indispensável para o desempenho do sistema. Ele precisa ser instruído para evitar o contato direto com a água não potável e também para estar atento durante as atividades de reformas consideradas de risco, ou seja, aquelas que podem comprometer o desempenho adequado do sistema. 


\section{APLICABILIDADE DOS REQUISITOS PROPOSTOS EM EDIFÍCIO}

RESIDENCIAL

Este capítulo apresenta uma avaliação dos requisitos e critérios de desempenho do SPAC e do SPAN em um edifício residencial e também a determinação do índice de falha desse sistema, por meio da ferramenta de modo e efeito de falha (FMEA) apresentada no capítulo 4.

\subsection{Características do Empreendimento}

O empreendimento estudado, além da implantação da fonte alternativa de água, possui sistema de aquecimento solar, equipamentos economizadores de água, fachada pré-fabricada, coleta seletiva de lixo entre outras inovações tecnológicas que propiciam o aumento da sustentabilidade no ambiente construído.

A concepção do sistema de fonte alternativa de água demandou a contratação de outros profissionais além do projetista de sistemas prediais como, por exemplo, de um consultor do Centro de Referência Internacional de Reúso de Água (CIRRA) para dar o suporte nas questões relativas ao sistema de água cinza.

As informações, tais como: volume dos reservatórios de água cinza, não potável e potável, especificação dos componentes, locação da estação de tratamento no subsolo, previsão de pontos de esgoto no local em que a estação de tratamento é instalada, etc; obtidas dos membros responsáveis pelo sistema seguiram a rotina apresentada na Figura 5.1. 
FASE I

CONCEPÇÃO DO PROJETO

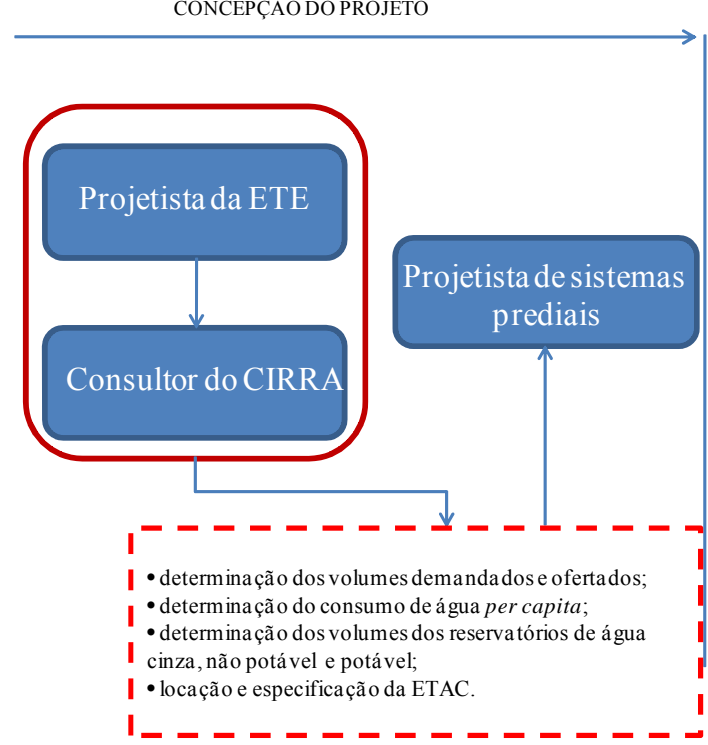

FASE II

EXECUÇÃO DO PROJETO

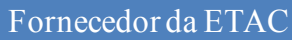

Figura 5.1 - Fluxo de informação entre os membros responsáveis pela implantação do sistema de água não potável em edifício residencial.

\subsection{Característica do Empreendimento}

O edifício estudado possui 24 pavimentos, sendo seis apartamentos em cada pavimento, totalizando 144 unidades residenciais, situadas na cidade de São Paulo - SP. Cada pavimento possui quatro apartamentos com $63 \mathrm{~m}^{2}$ e os dois apartamentos restantes, possuem $52 \mathrm{~m}^{2}$. A locação dos apartamentos no pavimento tipo encontra-se na Figura 5.2.

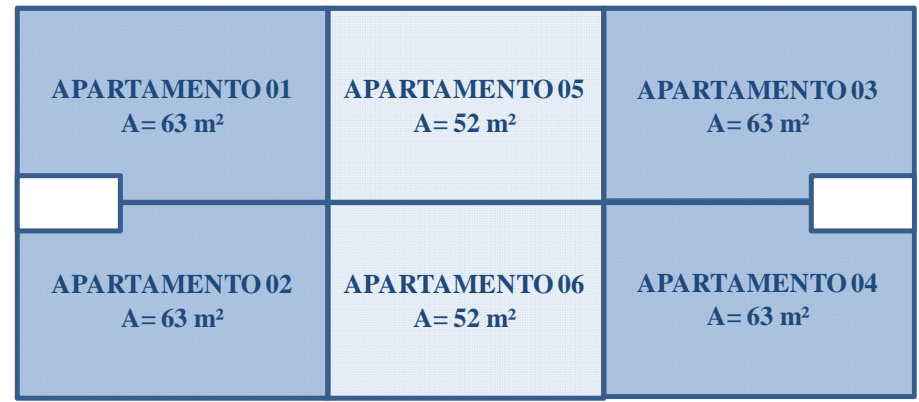

Figura 5.2- Locação dos apartamentos no pavimento tipo. 
Os apartamentos maiores, identificados como $\mathrm{n}^{\mathrm{o}}$ 1, 2, 3 e 4, possuem dois banheiros cada um; enquanto os menores, $\mathrm{n}^{\mathrm{o}} 5$ e 6 , dispõe de apenas um banheiro. Os banheiros existentes nos apartamentos $\mathrm{n}^{\mathrm{o}}$ 1, 2, 3 e 4 são conjugados $\mathrm{O}$ detalhe dos banheiros das unidades 3 e 4 encontra-se na Figura 5.3.

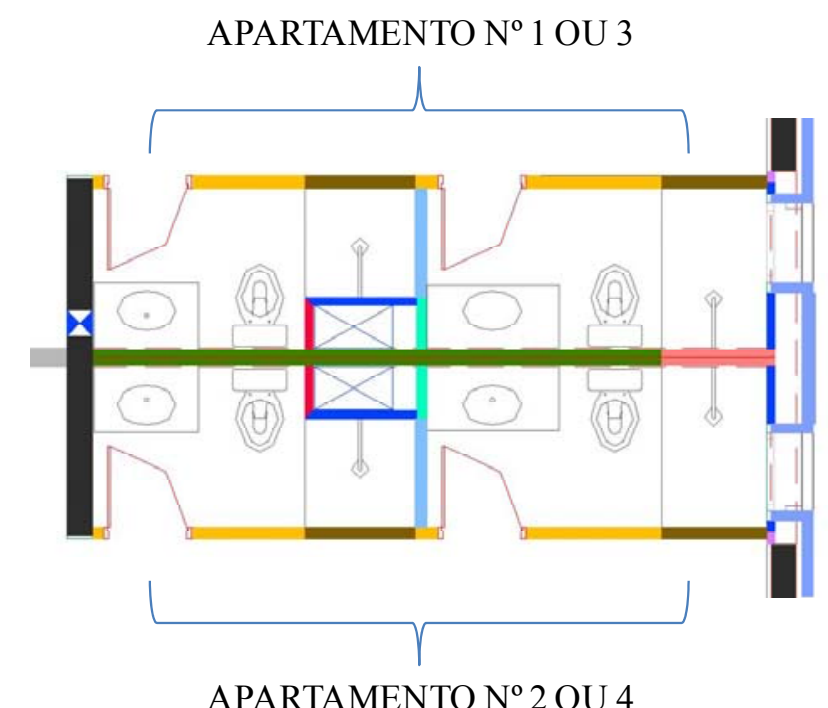

Figura 5.3 - Planta dos banheiros conjugados.

O sistema de fonte alternativa projetado reutiliza, após tratamento, toda a água cinza proveniente dos lavatórios e chuveiros, nas descargas das bacias sanitárias de todos os banheiros dos apartamentos.

\subsection{Característica do sistema predial de água não potável}

Este item apresenta resumidamente o modo que o subsistema foi projetado e executado no edifício estudado. Além da apresentação dessas fases, ainda constam as atividades de manutenção previstas para esse sistema. Ressaltam-se que os requisitos e critérios de desempenho de cada subsistema são detalhados nos itens 5.4 e 5.5, durante o estudo da sua aplicação, assim como da sua análise criteriosa.

\subsubsection{Projeto}

A implantação do sistema de água não potável fez com que o projeto previsse a separação dos sistemas prediais de coleta de esgoto sanitário: de águas negras e águas cinzas e de 
distribuição de água: potável e não potável. As águas cinzas dos lavatórios e chuveiros são coletadas separadamente das servidas nos outros equipamentos e a água não potável é distribuída apenas às descargas das bacias sanitárias, por tubulação independente da que distribui água potável.

O projeto contempla arejadores nos lavatórios e redutores de vazão nos chuveiros com valores médios de vazão de 0,1 1/s e $0,121 / \mathrm{s}$ respectivamente.

Os chuveiros dispõem de aquecimento por energia solar com complemento a gás, o que influencia diretamente no consumo de água deste componente. Conforme a NBR 5626 (ABNT, 1998) para sistemas com misturadores a vazão do chuveiro é 0,20 litros por segundo enquanto que para o chuveiro elétrico a vazão de projeto é de 0,10 litros por segundo.

\subsubsection{Execução}

O sistema predial de água foi executado por mão-de-obra terceirizada pela construtora e não houve treinamento. Segundo representante dessa empresa "montadora" dos sistemas prediais, a justificativa para a falta de treinamento deve-se à alta rotatividade de funcionários na sua empresa, impossibilitando assim treinamento contínuo da equipe.

Em relação à estação de tratamento houve contratação de empresa especializada. A contratada atua no mercado como executora de diferentes tipos de estação de tratamento como de água, esgoto e água cinza.

\subsubsection{Operação e manutenção}

As fases operação e manutenção são atividades de responsabilidade do condomínio. Como a construtora é responsável pela aquisição da estação de tratamento, optou-se por comprovar a sua eficiência antes da entrega aos moradores. Desta forma, elaborou-se o contrato com o fornecedor com uma cláusula impondo a análise da operação do sistema durante o período de três meses, com a emissão de laudos de análises físicas, químicas e biológicas do efluente tratado.

Além da comprovação da eficiência do sistema de tratamento de água cinza, a construtora comprovou a inexistência de conexão cruzada entre os sistemas de distribuição de água potável e não potável, e do sistema de coleta de águas cinzas e negras. Para isso, foi realizada 
a verificação a partir do fechamento das válvulas de água potável e não potável, identificando a fonte de água potável ou não potável, distribuída nos equipamentos sanitários.

A construtora entregou o edifício ao condomínio com a estação de tratamento operando com eficiência e com as tubulações de distribuição de água independentes. Cabe ressaltar que durante a entrega, a construtora disponibilizou o manual do proprietário, contendo as informações para a realização da manutenção do sistema de tratamento.

\subsection{O Subsistema predial de coleta de águas cinzas}

Os requisitos de desempenho para o SPAC estão descritos e analisados nos subitens a seguir.

\subsubsection{Requisito qualidade do efluente coletado}

A qualidade do efluente coletado para tratamento e distribuição de água não potável, contempla no projeto executado os critérios descritos a seguir.

\section{- Coletar apenas efluente passível de ser reutilizado}

O sistema de coleta de esgoto sanitário dos banheiros é formado pelos subsistemas de coleta de águas negras e de águas cinzas. A separação entre eles é feita por meio de ramais de descarga para os efluentes do lavatório e do chuveiro que se unem formando o ramal de água cinza que, por sua vez, se interliga com o tubo de queda de águas cinzas. As bacias sanitárias possuem seus ramais de descargas independentes dos ramais de águas cinzas, que são interligadas em tubo de queda exclusivo para as águas negras.

Cabe ressaltar que tanto nos banheiros conjugados, como nos simples de cada pavimento, existe apenas um tubo de queda para receber as águas cinzas. Como há dois banheiros simples e oito conjugados, tem-se dois grupos com quatro banheiros e um total de quatro tubos de queda de águas cinzas no edifício. A Figura 5.4 apresenta o detalhe do SPES de quatro banheiros conjugados, onde são identificados os componentes e diâmetros do SPAC. 


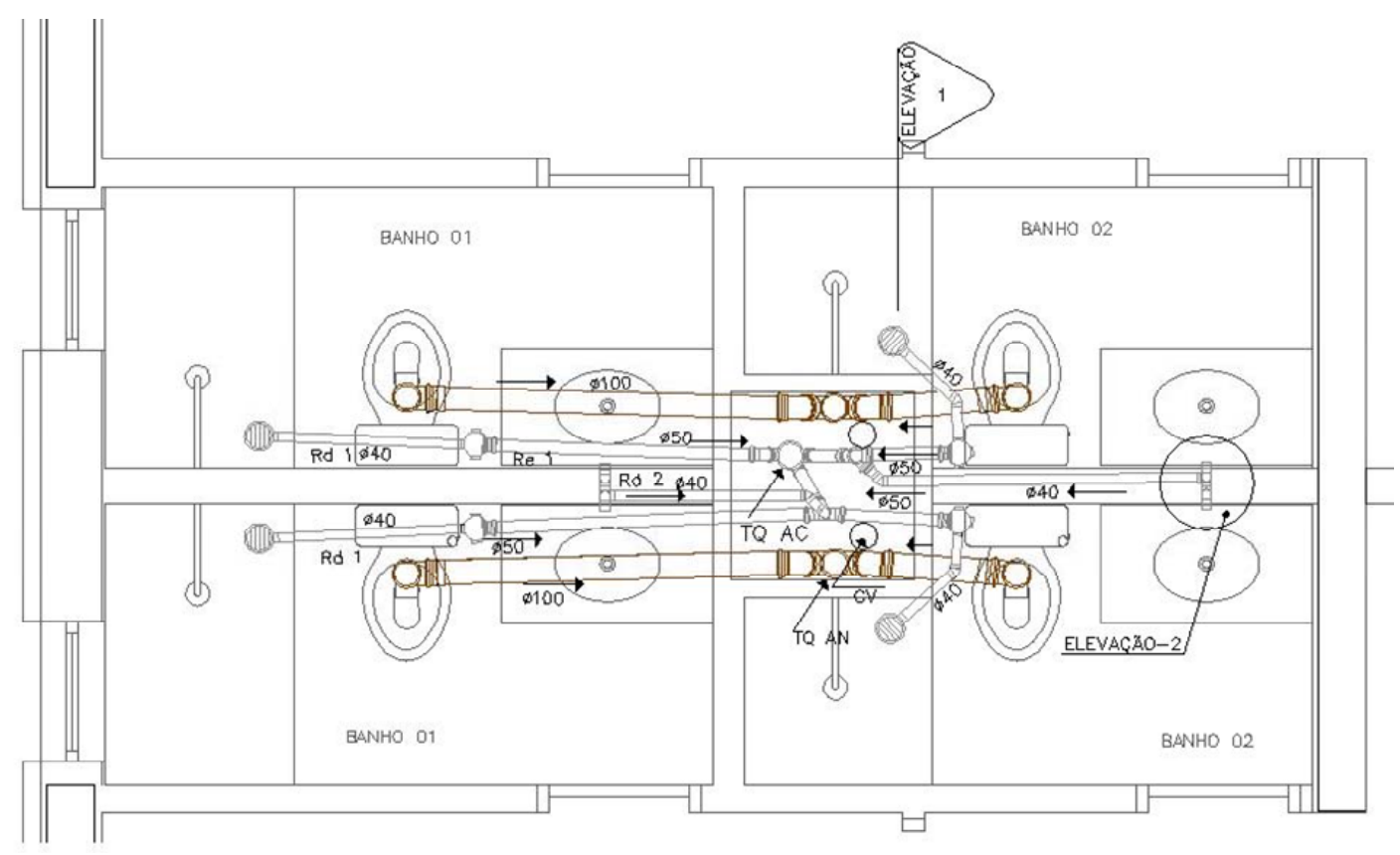

Figura 5.4 -Detalhe do sistema predial de esgoto sanitário dos banheiros conjugados.

De acordo com a Figura 5.4, percebe-se que existem dois tubos de queda de águas negras, independente do de água cinza. Para a coleta de águas cinzas dos quatro banheiros conjugados foi considerado apenas um tubo de $75 \mathrm{~mm}$ de diâmetro.
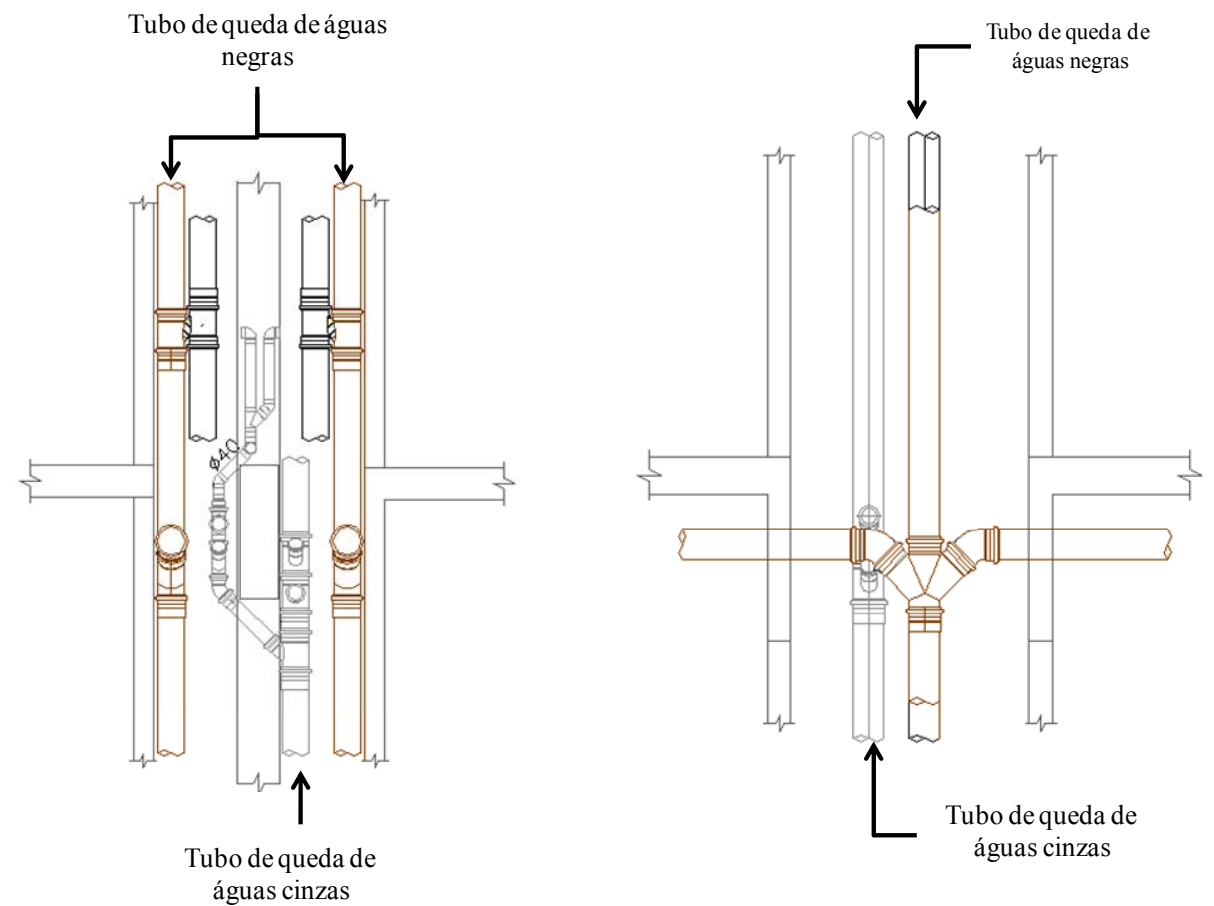

Figura 5.5 - Esquema vertical do SPAC do banheiro conjugado. 
Os condutores horizontais das águas cinzas estão localizados no $1^{\circ}$ subsolo do edifício, pavimento em que ocorre os desvios dos tubos de queda das águas cinzas até a estação de tratamento.

O projeto apresentado contempla a separação dos sistemas de coleta de água cinza e negra, o que garante o requisito de qualidade durante a fase do projeto, porém para a fase de execução não é possível garantir. Fatos indesejados podem ocorrer durante essa fase e propiciar a ocorrência de conexão cruzada entre os sistemas de coleta, principalmente quando não existe capacitação da mão-de-obra responsável pela execução dos sistemas prediais.

As tubulações que compõem o SPAC possuem características dos materiais semelhantes aos de águas negras, sendo utilizado o PVC soldável série normal. Ele foi utilizado tanto nos ramais de descarga e de esgoto quanto nos tubos de queda e subcoletores. A semelhança do material da tubulação propiciou a interligação inadequada, nos desvios das prumadas, dos subsistemas de coleta de águas cinzas e negras. Tal interligação foi identificada pelo fornecedor da estação de tratamento durante as suas atividades de manutenção, conforme descrito a seguir.

Como o efluente coletado foi analisado periodicamente, percebeu-se a diferença nos parâmetros das análises físico, química e bacteriológica em relação às previstas para as águas cinzas. Além da análise laboratorial, efetuou-se uma inspeção visual, sendo constatada a conexão cruzada, já que as águas negras contêm maior quantidade de sólidos quando comparadas as águas cinzas.

As tubulações expostas nos subsolos receberam pintura na cor cinza e são identificadas por meio de legendas nas paredes dos subsolos. Observa-se que no memorial descritivo de sistemas prediais não há previsão da programação visual das tubulações. Esta atividade foi uma iniciativa da construtora não havendo participação dos demais envolvidos no projeto.

A pintura das tubulações foi realizada durante a fase final da obra. A montadora contratada indicava as tubulações de águas cinzas, conforme orientação da construtora, para que uma terceirizada realizasse a pintura. Mesmo assim, o edifício foi entregue com identificação errada nas tubulações. A pintura só foi corrigida após a verificação da interligação das tubulações de águas cinzas e negras. Este erro poderia ter sido evitado caso a programação visual (pintura e legenda) tivesse ocorrido antes da instalação. 
Para manter a coleta apenas das águas cinzas, a construtora elaborou para o condomínio o manual do proprietário contendo o as built do apartamento e a recomendação da necessidade em manter os sistemas separados. Cabe ressaltar que o manual não prevê a periodicidade da pintura da tubulação bem como da manutenção das placas de identificação.

\subsubsection{Requisito disponibilidade}

- Descartar o efluente na rede de esgoto antes da estação de tratamento, quando necessário

O projeto prevê válvulas de gaveta com cunha de borracha, apresentadas na Figura 5.6, sendo uma à montante do reservatório de coleta de água cinza e outra na rede de esgoto, com o objetivo de controlar manualmente o fluxo, conforme as necessidades de operação e de manutenção.

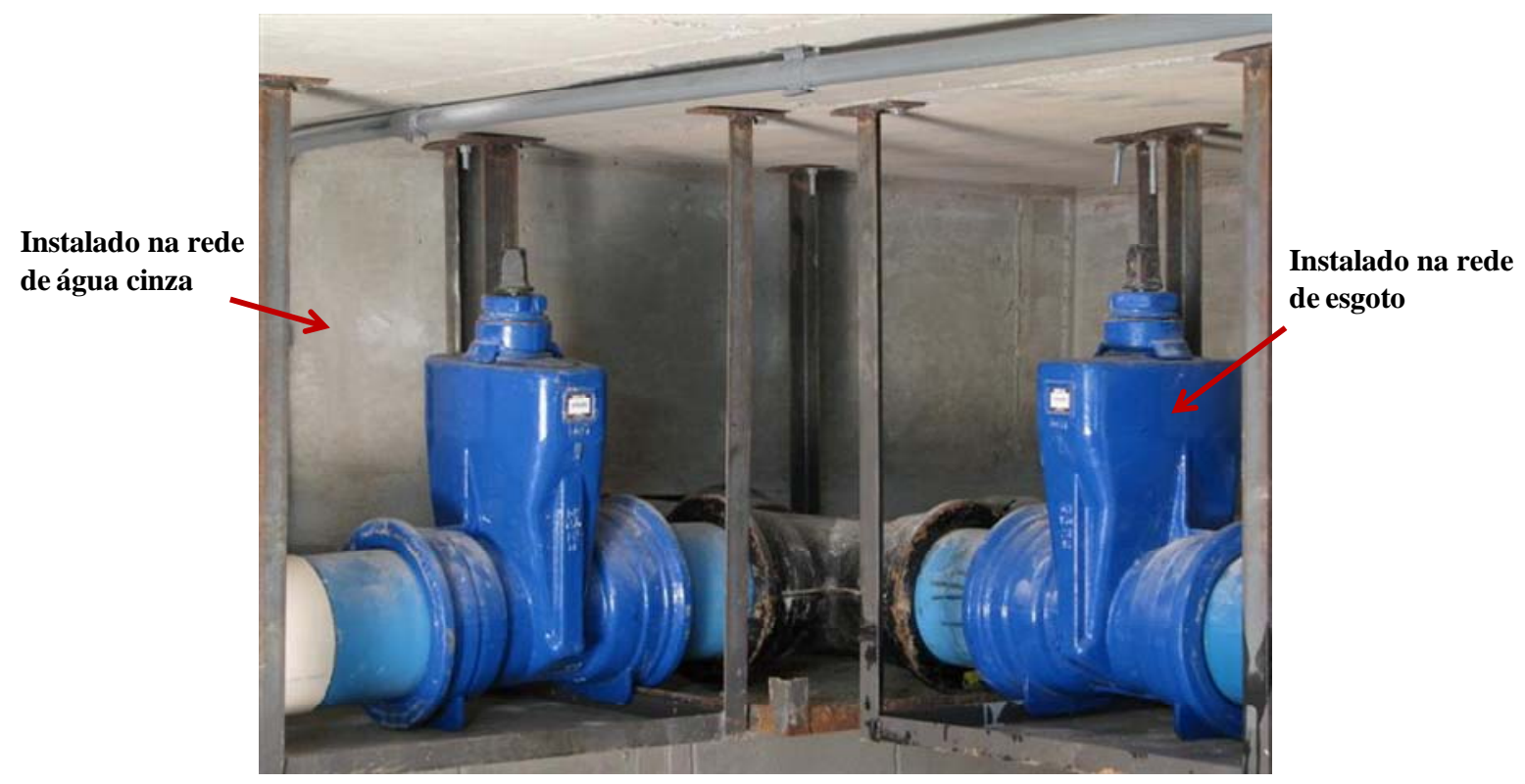

Figura 5.6 - Válvulas de gaveta com a função de bloquear ou permitir a entrada do efluente na estação de tratamento.

Conforme apresentado na Figura 5.6 a válvula instalada no sistema de água cinza é a recomendada na proposta dos requisitos do sistema predial de coleta de água cinza, para atender o requisito disponibilidade de água coletada. 


\section{- Instalar válvulas para limpeza do reservatório de coleta}

As válvulas para limpeza estão instaladas nas saídas do reservatório de coleta e do módulo da estação de tratamento e são operadas manualmente. As válvulas instaladas são de esfera e de PVC. A Figura 5.7 apresenta as válvulas instaladas no sistema.

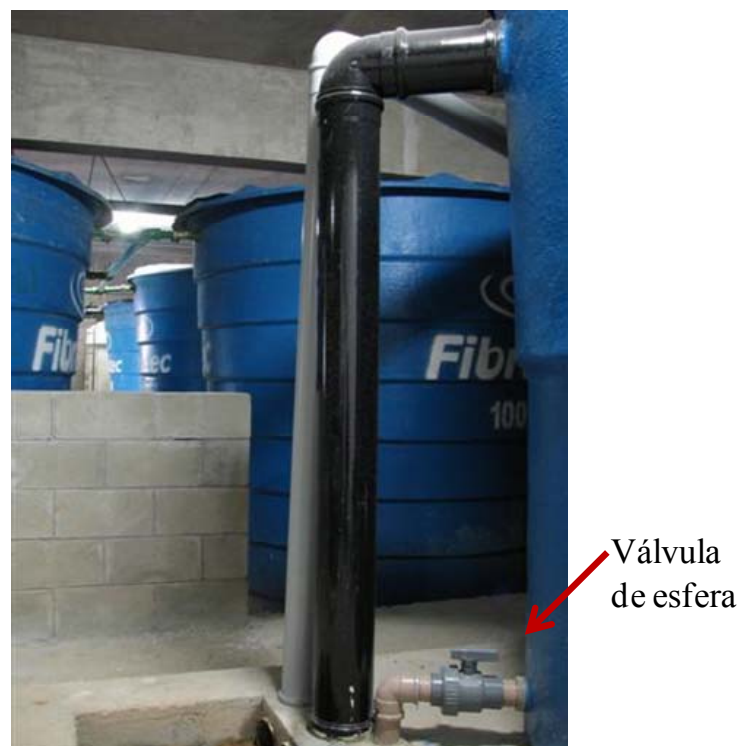

Figura 5.7- Válvula para limpeza, instalada na saída do reservatório de coleta de águas cinzas.

Além dessas válvulas, foi instalada na saída do módulo de tratamento, uma válvula solenóide conforme a Figura 5.8. A sua função é abrir automaticamente para descartar o lodo produzido pelo sistema de tratamento. Segundo o fornecedor a abertura é diária e por um período de dois minutos. Esse tempo foi obtido em função do tempo necessário para o descarte do lodo gerado pelo tratamento de água cinza. A abertura da válvula solenóide é realizada a partir de uma função do Comando Lógico Programável (CLP). 


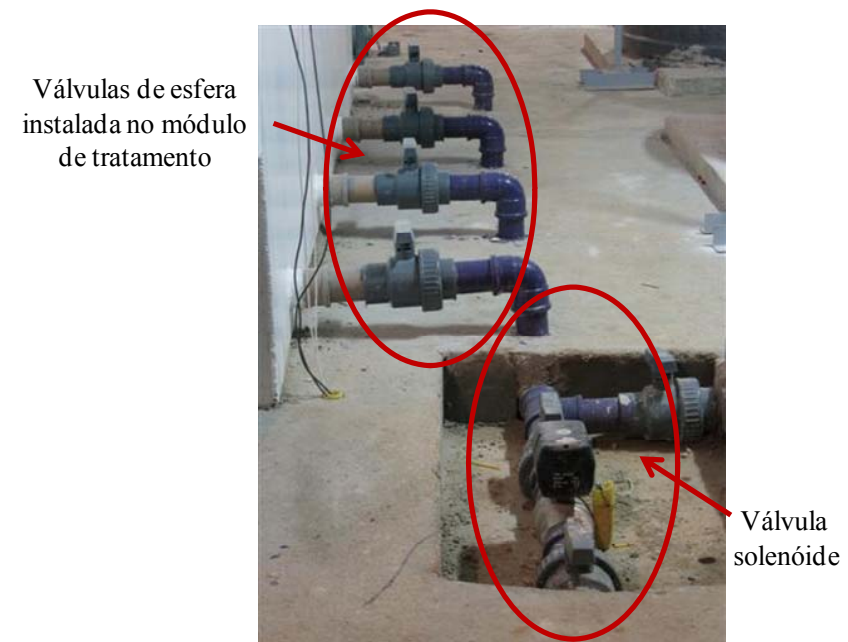

Figura 5.8 - Válvula solenóide para descarte do lodo da estação de tratamento.

A instalação das válvulas para limpeza do reservatório de água cinza e da ETAC está de acordo com o critério para atender o requisito disponibilidade, apresentado no capítulo 3 . Com a sua instalação e o correto funcionamento é garantido o destino adequado do efluente durante as atividades de manutenção.

- Instalar extravasor no reservatório de coleta de água cinza

O reservatório de coleta de água cinza é de fibra de vidro e está em conformidade com respectiva normas técnicas, tendo em vista que seu fabricante está qualificado pelo Programa Brasileiro de Qualidade e Produtividade do Habitat (PBQP-H). Nele encontra-se instalado o extravasor interligado com a rede de esgoto sanitário. A Figura 5.9 apresenta detalhe do extravasor instalado no reservatório de coleta de água cinza.

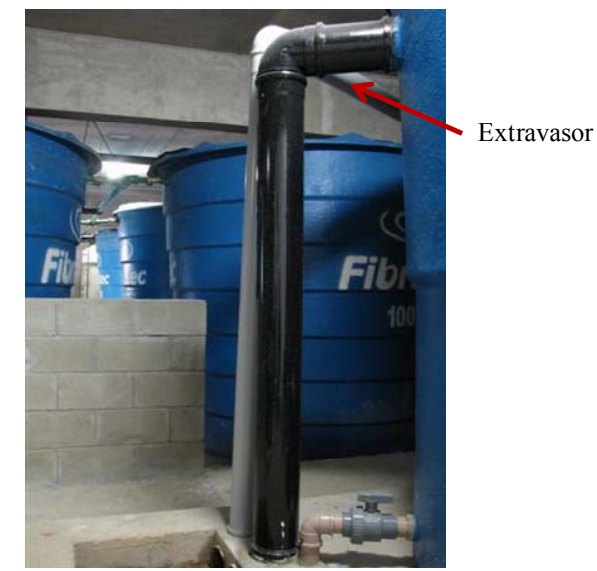

Figura 5.9 - Extravasor instalado no reservatório de coleta de água cinza. 
O extravasor possui diâmetro de $150 \mathrm{~mm}$ de diâmetro foi dimensionado corretamente, já que o volume excedente é extravasado livremente e encaminhado para a rede de esgoto.

\subsubsection{Requisito acessibilidade}

- Prever acesso na tubulação de coleta a cada 15 metros, caso exista curva de $90^{\circ}$ a inspeção deve ser após 1,5 metros

Ao analisar este requisito verifica-se que é atendido, pois todas as inspeções estão instaladas em distâncias menores das propostas no item 3.2. Esta acessibilidade facilita a identificação de ocorrência de obstrução do sistema. A Figura 5.10 mostra parte das inspeções dos componentes previstas no projeto.

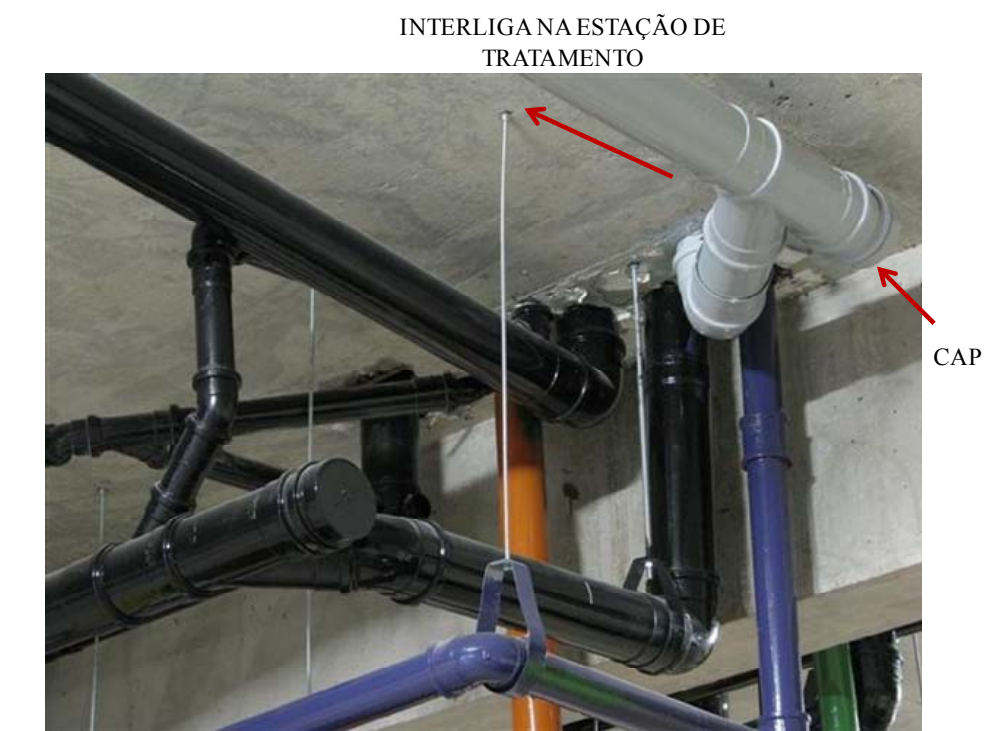

Figura 5.10 - Componentes de inspeção na tubulação do desvio do tubo de queda de água cinza.

\subsubsection{Requisito adequabilidade e quantidade}

- Tubulação de coleta possui diâmetro de acordo com a vazão de água cinza

O requisito refere-se ao dimensionamento dos componentes do SPAC do banheiro conjugado, que segundo projetista foi utilizado o método das UHC. Na Tabela 5.1 consta o resumo do dimensionamento, considerando as vazões dos equipamentos apresentadas na NBR 8160 (ABNT, 1999). Os componentes considerados são: 
O ramal de descarga 1 (Rd1): recebe os efluentes gerados em um chuveiro (ch), uma vazão de esgoto igual a $0,20 \mathrm{l} / \mathrm{s}$;

O ramal de descarga 2 (Rd2): recebe os efluentes gerados em um lavatório (lv), uma vazão de esgoto igual a 0,15 l/s;

$O$ ramal de esgoto 1 (Re1): recebe os efluentes gerados em um chuveiro e em um lavatório, ou seja uma vazão de 0,35 l/s;

O ramal de esgoto 2 (Re2): recebe os efluentes gerados em dois chuveiros e dois lavatórios, ou seja uma vazão de $0,70 \mathrm{l} / \mathrm{s}$;

Tabela 5.1 - Dimensões dos ramais do SPES, utilizando o método das UHC (NBR 8160, 1999)

\begin{tabular}{cccc}
\hline \hline Trecho & $\mathbf{N}^{\circ}$ UHC & Q (l/s) & D mín (mm) \\
\hline \hline $\operatorname{Rd} 1-1 \mathrm{ch}$ & 2 & 0,20 & 40 \\
\hline $\operatorname{Rd} 2-1 \mathrm{lv}$ & 1 & 0,15 & 40 \\
\hline $\operatorname{Re} 1-1 \mathrm{ch}+1 \mathrm{lv}$ & 3 & 0,35 & 40 \\
\hline $\operatorname{Re} 2-2 \mathrm{ch}+2$ lv & 6 & 0,70 & 50 \\
\hline
\end{tabular}

O tubo de queda: recebe as águas cinzas e possui $75 \mathrm{~mm}$ de diâmetro.

A coluna de ventilação: o projeto inicial não previu.

A aplicação do método das UHC para o dimensionamento do tubo de queda de água cinza, considerando a contribuição de quatro banheiros conjugados em cada pavimento resulta um total de 288 UHC (3 UHC x 24 pavimentos x 4 banheiros). Segundo a NBR 8160 (ABNT, 1999), o tubo de queda com $75 \mathrm{~mm}$ de diâmetro suporta no máximo 75 UHC, e para esse cenário de 288 UHC a referida norma recomenda a utilização de tubo com $100 \mathrm{~mm}$ de diâmetro. De acordo com a informação do projetista, o sistema foi dimensionado de acordo com as suas experiências práticas.

As dimensões apresentadas dos componentes são comparadas com as obtidas no dimensionamento hidráulico. As vazões consideradas no dimensionamento são de acordo com a publicada na referida norma. A Tabela 5.2 apresenta as dimensões dos diâmetros dos ramais de descarga, esgoto, tubo de queda e coluna de ventilação. 
Tabela 5.2 - Diâmetros das tubulações dos SPAC, conforme método UHC e Hidráulico

\begin{tabular}{c|c|c|c|c}
\hline \hline \multirow{2}{*}{ Componente do SPES } & \multicolumn{4}{|c}{ Método de dimensionamento } \\
\cline { 2 - 5 } & UHC & Qe & D 3/4** & D nom \\
\cline { 2 - 5 } & D mín & $\mathbf{( L / s )}$ & $\mathbf{( m m )}$ & (mm) \\
\cline { 2 - 5 } & $\mathbf{( m m )}$ & 0,20 & 25 & 40 \\
\hline RD1 - 1ch & 40 & 0,15 & 30 & 40 \\
\hline RD 2 -1 lv & 40 & 0,35 & 39 & 40 \\
\hline RE 1-1ch +1 lv & 40 & 0,70 & 99 & 40 \\
\hline RE 2 - 2ch + 2 lv & 50 & $6,55^{*}$ & & 75 \\
\hline Tubo de queda & 100 & & & \\
\hline
\end{tabular}

*Vazão obtida considerado o fator de simultaneidade: 26 chuveiros e 9 lavatórios.

** $3 / 4$ do preenchimento do tubo.

Para o dimensionamento dos ramais são considerados $3 / 4$ do preenchimento do tubo com o efluente, e o coeficiente de Manning considerado é 0,010, tubo PVC. Os valores das declividades variam de acordo com o diâmetro da tubulação, para os menores iguais a $75 \mathrm{~mm}$, a declividade é $2 \%$, para os maiores que $75 \mathrm{~mm}$ a declividade é $1 \%$.

O método preconiza que o dimensionamento do tubo de queda é influenciado pelo número de aparelhos em uso simultâneo, que para essa tipologia, corresponde a 26 chuveiros e 9 lavatórios. A vazão por equipamento considerada, conforme a NBR 8160 (ABNT, 1999) é de $0,20 \mathrm{l} / \mathrm{s}$ para os chuveiros e $0,15 \mathrm{l} / \mathrm{s}$ para os lavatórios, com esses dados obtêm a vazão de projeto de $6,551 / \mathrm{s}$.

A pressão hidráulica no interior do tubo de queda, considerando a vazão de 6,55 1/s, foi superior a $375 \mathrm{KPa}$, valor considerado limite de suficiência da ventilação primária (GRAÇA, 1985), ou seja, para essa situação, utilizando as vazões propostas pela NBR 8160 é necessário instalar a ventilação secundária no tubo de queda. Diante dessa situação, o projetista de sistemas prediais do edifício estudado decidiu inserir o sistema de ventilação para esse tubo de queda de coleta de águas cinzas.

Em suma, a aplicação do método das UHC resultou: $100 \mathrm{~mm}$ de diâmetro do tubo de queda de água cinza e $100 \mathrm{~mm}$ para a coluna de ventilação; enquanto que o método hidráulico, quando considerada as vazões dos equipamentos publicadas na NBR 8160 (1999) o tubo de queda e a coluna de ventilação seria de $75 \mathrm{~mm}$ de diâmetro. Os diâmetros obtidos são menores quando utilizado o método hidráulico, ou seja, considerando o número de aparelhos em uso simultâneo. 
Apresentada a descrição do sistema predial de coleta de água cinza, a sua fase projeto, execução e manutenção foi elaborada a Tabela 5.3. Ela apresenta de modo resumido o estudo da aplicabilidade dos requisitos de desempenho do SPAC, atendidos no empreendimento.

Tabela 5.3 - Resumo dos requisitos do SPAC, atendidos nos empreendimentos.

\begin{tabular}{|c|c|c|c|c|}
\hline SISTEMA & ETAPA & $\begin{array}{l}\text { REQUISITO DE } \\
\text { DESEMPENHO }\end{array}$ & CRITÉRIOS & $\begin{array}{c}\text { Grau de } \\
\text { atendimento }\end{array}$ \\
\hline $\begin{array}{l}\mathbf{P} \\
\mathbf{R} \\
\mathbf{E}\end{array}$ & PROJETO & Qualidade & $\begin{array}{l}\text { Sistema de coleta de águas cinzas independente das } \\
\text { águas negras. }\end{array}$ & SIM \\
\hline $\begin{array}{l}\text { D } \\
\text { I } \\
\text { A }\end{array}$ & PROJETO & Disponibilidade & $\begin{array}{l}\text { Descartar o efluente na rede de esgoto antes da } \\
\text { estação de tratamento quando necessário. }\end{array}$ & SIM \\
\hline $\begin{array}{l}\text { D } \\
\text { E }\end{array}$ & PROJETO & Acessibilidade & $\begin{array}{l}\text { Possuir acesso na tubulação de esgoto para inspeção } \\
\text { a cada } 15 \mathrm{~m} \text {, caso exista curva de } 90^{\circ} \text { a inspeção deve } \\
\text { ser após } 1,5 \mathrm{~m} \text {. }\end{array}$ & SIM \\
\hline $\begin{array}{l}\text { C } \\
\text { o } \\
\text { L }\end{array}$ & PROJETO & Adequabilidade & $\begin{array}{l}\text { Possuir diâmetro interno na tubulação no mínimo de } \\
75 \mathrm{~mm} \text {. }\end{array}$ & SIM \\
\hline $\begin{array}{l}\mathrm{E} \\
\mathrm{T} \\
\mathrm{A}\end{array}$ & PROJETO & Odores & Prever a instalação de sistema de ventilação. & SIM \\
\hline $\begin{array}{l}\text { C } \\
\text { I } \\
\text { N }\end{array}$ & EXECUÇÃO & Qualidade & Treinar a mão-de-obra. & NÃO \\
\hline $\begin{array}{l}\text { U } \\
\text { A } \\
\text { S }\end{array}$ & $\begin{array}{c}\text { OPERAÇÃO/MANUTENÇÃ } \\
\text { O }\end{array}$ & Qualidade & Identificar as tubulações. & $20 \%$ \\
\hline
\end{tabular}

De acordo com o apresentado todos os requisitos e critérios de desempenho foram inseridos no sistema. A exceção ocorreu no referente ao treinamento da mão-de-obra, que interfere diretamente em manter a separação dos subsistemas de coleta e conseqüentemente manter a qualidade da água coletada. Além dessa exceção, pode-se também considerar a falta de identificação de todas as tubulações, de acordo com o apresentado, a pintura das tubulações ocorreu apenas nas instaladas nos subsolos do edifício, e não em todas as existentes, conforme sugerido pela autora.

Como não é possível determinar a quantidade da tubulação instalada no subsolo e quanto ela representa da total existente, considerou-se $20 \%$ de atendimento para esse critério. 


\subsection{Estação de Tratamento de Água Cinza - ETAC}

O fornecedor da ETAC foi contratado durante a execução do sistema. Ressalta-se que ele projetou a estação de tratamento diferente da prevista na fase projeto do empreendimento.

A ETAC instalada no subsolo do empreendimento, opera em batelada empregando tratamento físico - químico. Segundo o fabricante e projetista dessa estação, para essa tipologia de edifício, esse tipo de tratamento é o mais viável, por demandar menor área para implantação e possuir custo menor quando comparado aos demais tipos de tratamento. O esquema da estação de tratamento está na Figura 5.11.

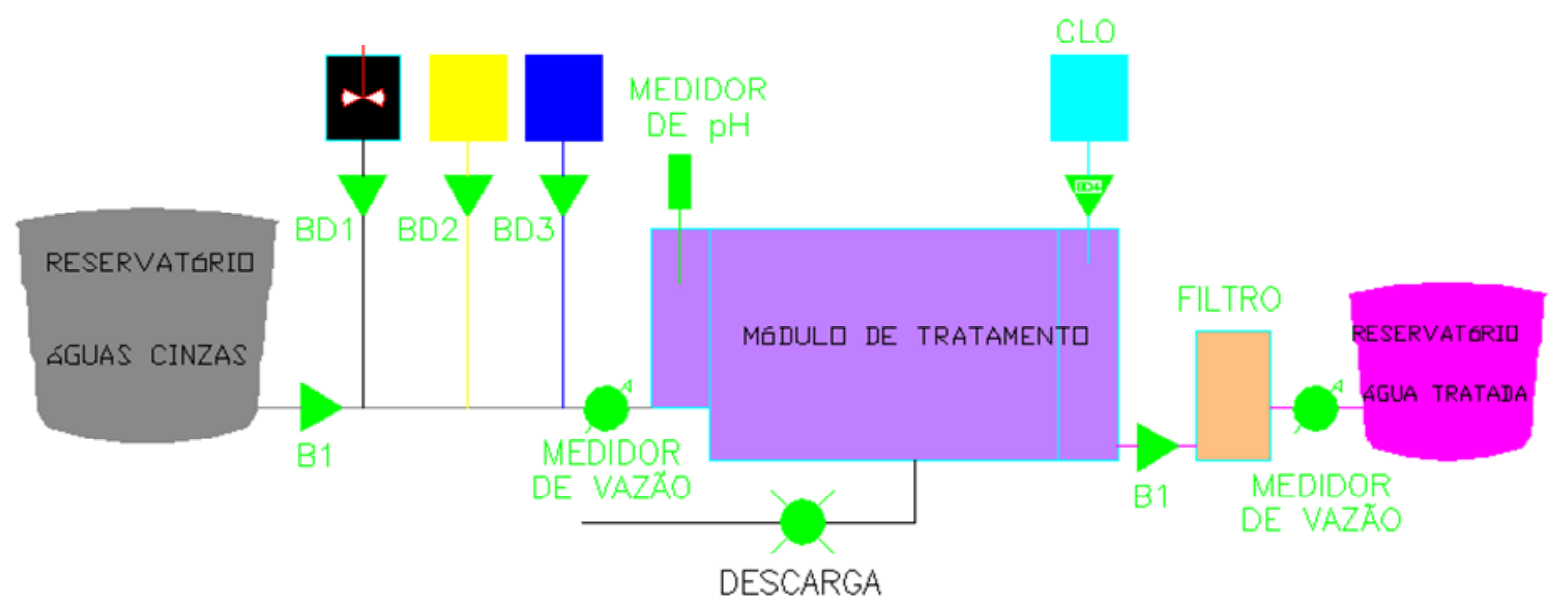

Figura 5.11 - Sistema de tratamento físico-químico implantado no empreendimento.

O tratamento é realizado pela adição de produtos químicos: sulfato de alumínio ${ }^{6}$, cal, polímero e cloro com objetivos de coagular, neutralizar, flocular e desinfetar a água cinza para torná-la com padrões adequados ao uso em bacias sanitárias. A ETAC opera automaticamente, através do CLP, sendo acionada quando o reservatório de água não potável atinge seu nível mínimo.

\footnotetext{
${ }^{6}$ Sulfato de alumínio isento de ferro para não manchar as louças sanitárias.
} 


\subsubsection{Requisito Quantidade}

O requisito é atendido a partir da análise do volume demandado e do ofertado. A construtora solicitou diversas análises realizadas pela projetista da ETAC, pelo consultor do CIRRA e pelo fornecedor da ETAC. O projetista dos sistemas prediais não participou da análise, apenas recebeu a informação e a considerou na capacidade dos reservatórios de água tratada.

A Tabela 5.4 apresenta uma comparação dos volumes de água cinza e as variáveis consideradas na determinação desses volumes pelo CIRRA e pela projetista da estação de tratamento de águas cinzas. Segundo as informações obtidas pelo CIRRA, a ETAC trataria volume excedente diário de 25,92 litros por habitante, enquanto que a projetista da estação, o valor seria de 45 litros. Os envolvidos afirmam que os dados foram retirados de informações dos fabricantes como também de pesquisas.

O fornecedor da ETAC realizou a análise dos volumes, mas não informou a metodologia utilizada. Afirmou que não há excedente, devido a existência das perdas de água que podem ocorrer no sistema, equilibrando o volume demandado com o ofertado. Assim, a ETAC trata toda a água cinza produzida pelos lavatórios e chuveiros do edifício.

Tabela 5.4 - Comparação dos valores de consumo de água cinza obtidos do CIRRA e da projetista da ETAC.

\begin{tabular}{|c|c|c|c|c|c|c|c|c|}
\hline \multirow{2}{*}{ Equipamento } & \multicolumn{2}{|c|}{$\begin{array}{c}\text { Duração de } \\
\text { utilização (s) }\end{array}$} & \multicolumn{2}{|c|}{$\begin{array}{l}\text { Freqüência de } \\
\text { acionamentos }\end{array}$} & \multicolumn{2}{|c|}{ Vazão de água (l/s) } & \multicolumn{2}{|c|}{ Volume diário (l) } \\
\hline & Cirra & Projetista & Cirra & Projetista & Cirra* & Projetista* & Cirra & Projetista \\
\hline Lavatórios & 12 & 12 & 6 & 6 & 0,12 & 0,10 & 15,12 & 12,6 \\
\hline Chuveiros & 480 & 480 & 1 & 1 & 0,085 & 0,13 & 40,8 & 62,4 \\
\hline $\begin{array}{c}\text { Bacia } \\
\text { sanitária }\end{array}$ & & & 5 & 5 & $61^{* *}$ & $61^{* *}$ & 30 & 30 \\
\hline \multicolumn{7}{|c|}{ EXCEDENTE (l/hab.dia) $=(\mathbf{l v}+$ ch $)-($ bs $)$} & 25,92 & 45 \\
\hline
\end{tabular}

*dados obtidos de fabricantes e de pesquisas acadêmicas.

**volume considerado no acionamento da descarga da bacia sanitária: seis litros.

Considerando-se a inexistência dos valores dessas variáveis em normas técnicas, observa-se grande variação entre os valores obtidos pelos projetistas.

Os valores de consumo apresentados na Tabela 5.4 confirmam o volume de água cinza excedente, porém não está previsto o seu descarte antes da ETAC. Tal situação pode proporcionar o maior volume de água do que o necessário. Como já foi apresentado, uma 
forma de evitar o descarte do volume excedente é fazer a coleta seletiva das águas cinzas, isto é coletar apenas parte dos tubos de quedas e os demais desviá-los para a rede de esgoto.

\subsubsection{Requisito Qualidade, Durabilidade, Preservação da Natureza e Resistência Mecânica}

A estação de tratamento de água cinza prevista em projeto, não possui material translúcido na sua composição. Todos os componentes são opacos, dificultando assim, a infiltração da luz solar. A Figura 5.12 ilustra parte dos componentes da estação de tratamento.

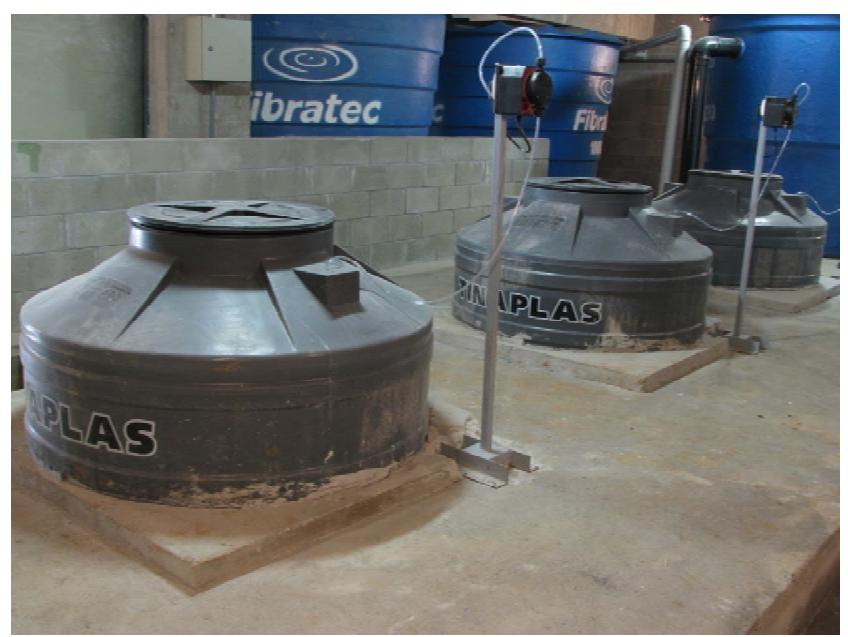

a)

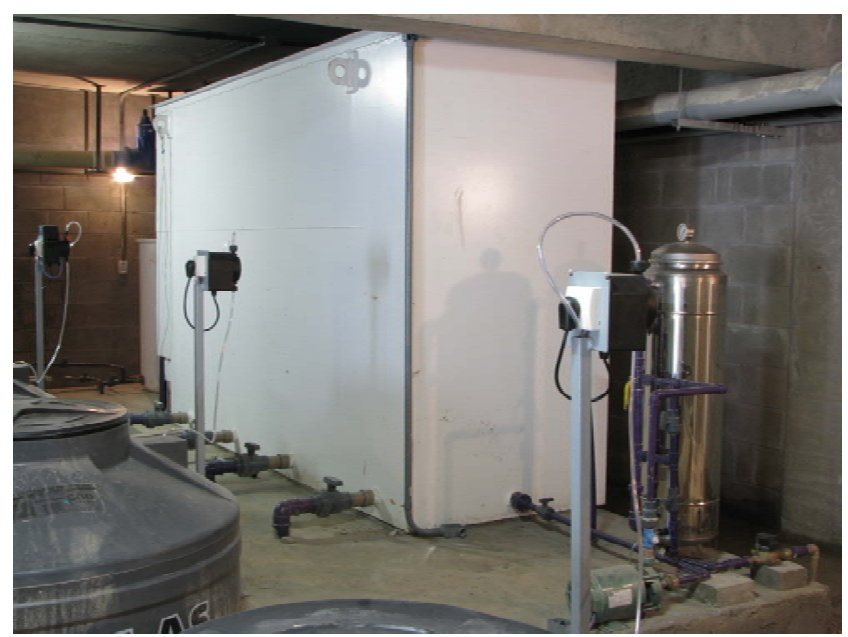

b)

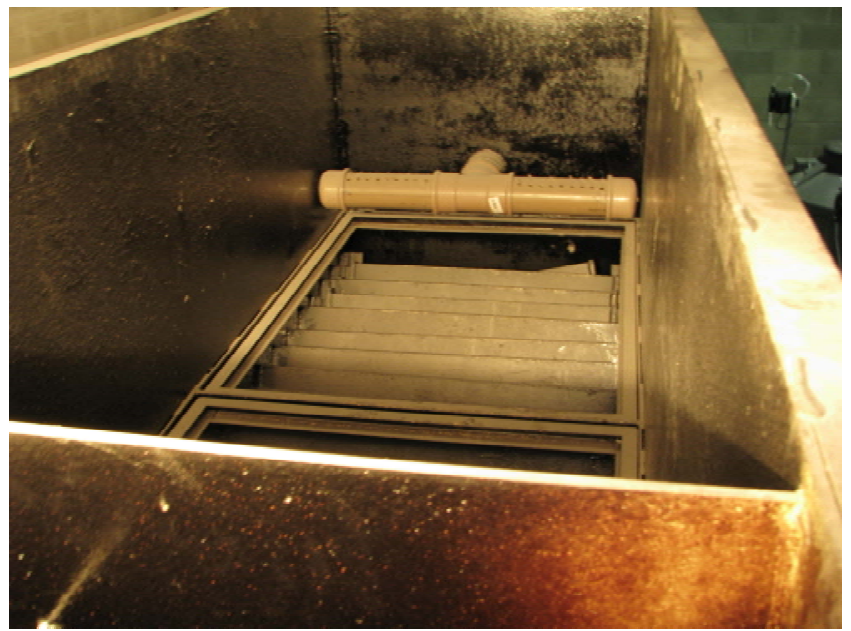

C)

Figura 5.12 - Componentes da ETAC: (a)Reservatório de armazenamento de produtos químicos, (b)módulo de tratamento e (c) vista superior do módulo de tratamento.

Dentre os componentes da estação de tratamento de água cinza, foi possível comprovar apenas a certificação do reservatório destinado aos produtos químicos. Ele está em 
conformidade com as normas específicas e participa do programa setorial da qualidade do Programa Brasileiro da Qualidade e Produtividade do Habitat - PBQP-H. Observa-se que a participação requerida para o reservatório, corresponde para o armazenamento de água cinza e não para a estocagem de produtos químicos.

A estação de tratamento implantada é apoiada no piso do subsolo. Como a estação não está enterrada, o requisito preservação da natureza é desconsiderado da análise, tendo em vista que ele é considerado para os casos em que a estação de tratamento encontra-se enterrada.

No sistema predial de água não potável, o requisito de resistência mecânica é relacionado com a capacidade de suportar a pressão hidrostática do efluente no tanque. Além dessa solicitação ainda deve ser capaz de suportar a pressão do solo, caso enterrado. Como a estação encontrase apoiada no solo, deve-se considerar apenas a pressão do efluente nas paredes da estação de tratamento.

Não foram obtidas as informações dos demais componentes, com exceção do reservatório dos produtos químicos. Considera-se que a inexistência da informação dificulta a conclusão da análise desses requisitos que precisam estar em conformidade com as normas técnicas.

\subsubsection{Requisito Operação}

O tipo de tratamento utilizado é o físico-químico, o que exige a inserção de produtos químicos no efluente, durante a operação do sistema. Existe próximo da estação de tratamento uma Central Lógica Programável (CLP), apresentado na Figura 5.13, com as ações necessárias para a operação do sistema, tais como:

- o acionamento da bomba responsável pela passagem da água cinza para o módulo de tratamento;

- a medição do pH;

- ligar as bombas dosadoras de produtos químicos no efluente;

- o acionamento da bomba para encaminhar o efluente para o filtro de areia. 

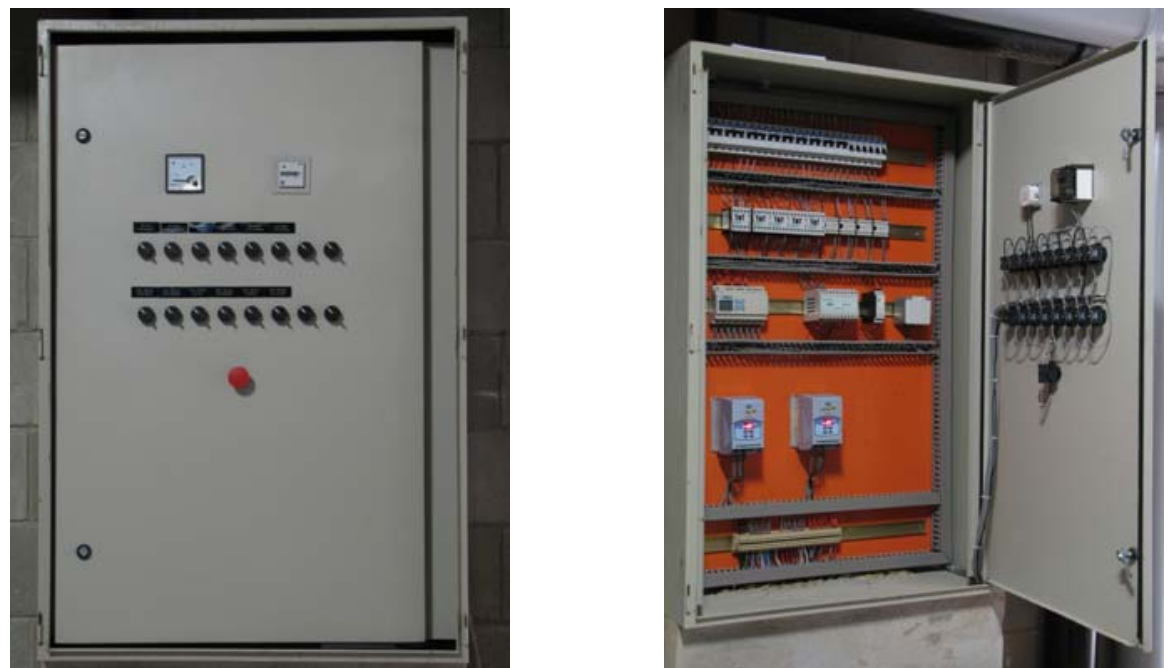

Figura 5.13 - Central Lógica Programável (CLP) - sistema de informação responsável pela automatização da estação de tratamento.

O funcionamento da ETAC varia de acordo com o nível da água não potável no reservatório. O automático de bóia, instalado neste reservatório tem a função de acionar a bomba responsável pela condução da água cinza para o módulo de tratamento. Tal acionamento ocorre quando o nível de água não potável atinge o nível mínimo estabelecido pelo projetista.

Portanto, a operação do sistema varia somente de acordo com o volume demandado pelas bacias sanitárias e não depende do volume ofertado nem do tempo de armazenamento da água cinza no reservatório de coleta. Assim, não é possível garantir um período máximo de armazenamento de 24 horas, considerada neste trabalho, como a condição limite para a possibilidade de iniciar o processo de biodegradação e, conseqüentemente, a presença do mau cheiro no ambiente.

Apresentados os requisitos para a ETAC, segue na Tabela 5.5 o resumo dos requisitos atendidos no empreendimento. A avaliação dos requisitos e critérios de desempenho para a estação de tratamento foi considerada difícil, devido à indisponibilidade de dados referentes ao sistema e por não estar em nenhum Programa Setorial da Qualidade do PBQP-H.

O requisito quantidade não foi atendido, porque não há descarte do efluente antes da estação de tratamento, ou seja, todo o volume de águas cinzas produzido é coletado e tratado. $\mathrm{O}$ requisito preservação da natureza não é considerado nesse estudo devido a inexistência de reservatórios enterrados. 
Tabela 5.5 Resumo dos requisitos atendidos da ETAC

\begin{tabular}{|c|c|c|c|c|}
\hline SISTEMA & ETAPA & $\begin{array}{l}\text { REQUISITO DE } \\
\text { DESEMPENHO }\end{array}$ & CRITÉRIOS & $\begin{array}{c}\text { Grau de } \\
\text { atendimento }\end{array}$ \\
\hline \multirow{7}{*}{$\begin{array}{l}\text { E } \\
\text { T } \\
\text { A } \\
\text { C }\end{array}$} & PROJETO & Quantidade & $\begin{array}{l}\text { Dimensionar o reservatório de acordo com o } \\
\text { volume demandado de água no ponto de utilização } \\
\text { de água não potável. }\end{array}$ & NÃo \\
\hline & PROJETO & Qualidade & $\begin{array}{l}\text { Nenhum elemento do sistema pode utilizar material } \\
\text { translúcido }\end{array}$ & * \\
\hline & PROJETO & Durabilidade & $\begin{array}{l}\text { A estação deve ser construída com material não } \\
\text { biodegradável }\end{array}$ & SIM \\
\hline & PROJETO & Disponibilidade & $\begin{array}{l}\text { Prever a instalação de dispositivos de limpeza em } \\
\text { todos os componentes da estação de tratamento }\end{array}$ & SIM \\
\hline & PROJETO & $\begin{array}{l}\text { Preservação da } \\
\text { Natureza }\end{array}$ & Impermeabilizar reservatórios enterrados & $* *$ \\
\hline & PROJETO & $\begin{array}{l}\text { Resistência } \\
\text { Mecânica }\end{array}$ & $\begin{array}{l}\text { O reservatório deve ser capaz de suportar a pressão } \\
\text { hidrostática existente no interior do reservatório, } \\
\text { bem como do solo (quando o reservatório for } \\
\text { enterrado) }\end{array}$ & * \\
\hline & PROJETO & Operação & A estação de tratamento deve ser fácil de operar & SIM \\
\hline
\end{tabular}

*A falta de dados do fabricante impossibilitou analisar esse requisito.

** Requisito desconsiderado da análise, pois o reservatório está apoiado no solo.

\subsection{O sistema predial de água não potável}

O subsistema predial de água de não potável é composto pelo sistema de armazenamento e pelo de distribuição dessa água. Apresenta dois reservatórios sendo um no subsolo e outro na cobertura, que alimenta o sistema de distribuição. Cabe ressaltar que o edifício não possui a previsão de medição individualizada de água (potável e não potável).

A Figura 5.14 apresenta a isométrica do reservatório superior de água potável e não potável, com o seu barrilete e a sua coluna de distribuição. 


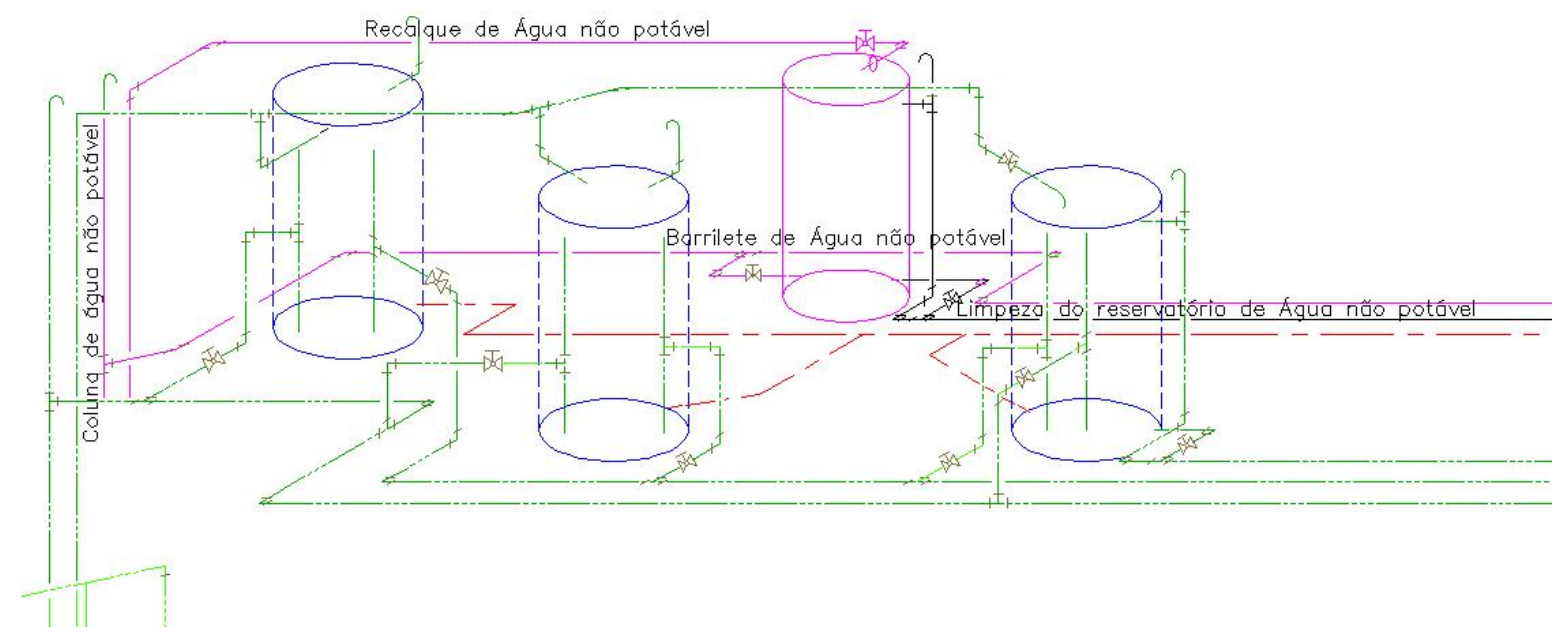

Figura 5.14 - Isométrica dos reservatórios superiores de água potável e não potável (representado pela cor roxa).

A coluna oriunda do reservatório superior abastece as descargas das bacias sanitárias do $24^{\circ}$ ao $13^{\circ}$; os demais pavimentos, $1^{\underline{0}}$ ao $12^{\underline{0}}$ por estarem localizados em zona de pressão superior a $400 \mathrm{KPa}$, são abastecidos a partir da válvula redutora de pressão, instalada no subsolo.

As descargas das bacias sanitárias dos banheiros conjugados são abastecidas por uma única coluna de água não potável. Essa coluna se ramifica, em cada pavimento e distribui a água para as quatro bacias sanitárias, de acordo com a isométrica dos banheiros conjugados apresentado na Figura 5.15. 


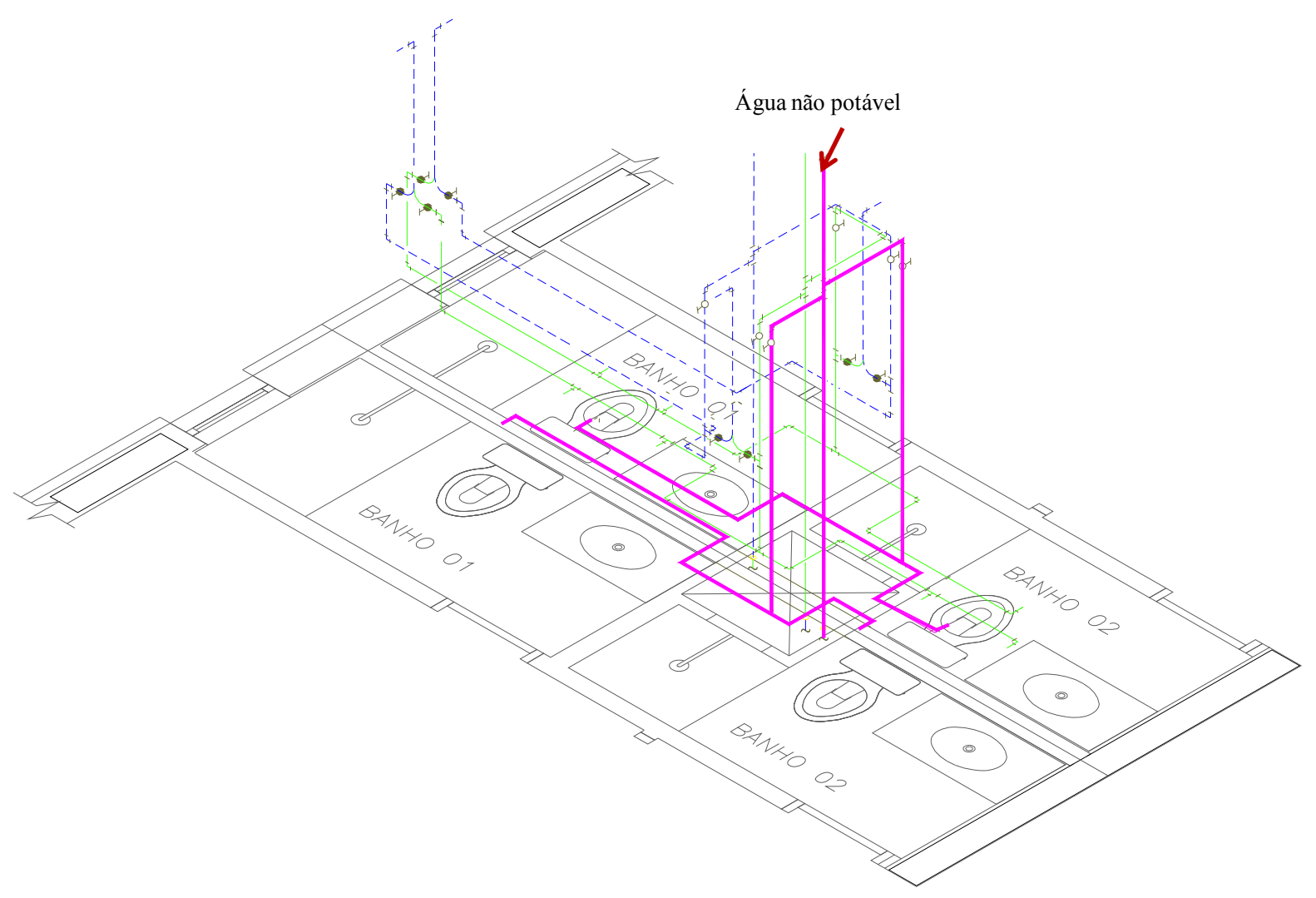

Figura 5.15 - Isométrica dos banheiros conjugados

Apresentadas as características do sistema de distribuição implantado, analisa-se a aplicabilidade dos requisitos e critérios.

\subsubsection{Requisito adequabilidade}

- Não utilizar materiais que reduza a qualidade da água não potável

O material utilizado no sistema predial de água não potável é semelhante ao utilizado no potável. Para o reservatório inferior e superior foi utilizado reservatório de fibra de vidro, tubulação de recalque em polipropileno (PPR) e distribuição em PVC soldável.

Não foi realizado teste na tubulação para verificação do comportamento das suas características após longo período de exposição à água não potável. Assim, não é possível afirmar, que a tubulação é a mais adequada para esse sistema de distribuição. 


\subsubsection{Requisito Qualidade}

\section{- Prever a monitoração periódica da qualidade da água tratada}

A monitoração da qualidade da água corresponde a uma atividade que deve ser prevista na fase de operação. A construtora, com objetivo de verificar a eficiência do sistema de tratamento, inseriu uma cláusula extra no contrato com a empresa fornecedora da ETAC. Essa cláusula afirma que o fornecedor receberia o pagamento do serviço depois da comprovação da eficiência da estação de tratamento, por período de três meses de operação. Os parâmetros físicos, químicos e biológicos selecionados para análise da eficiência são os exigidos pela EPA (1992), que são o pH, $\mathrm{DBO}_{5}$, turbidez e coliformes termotolerantes.

Segundo o fornecedor o padrão de qualidade da água obtido após o sistema de tratamento é semelhante ao publicado pela Portaria $\mathrm{n}^{\mathrm{o}}$ 518, porém não é possível afirmar que essa qualidade permanecerá constante durante a operação do sistema.

Em relação ao atendimento do requisito qualidade, afirma-se que a construtora comprovou a eficiência da estação de tratamento e que após essa etapa a responsabilidade é do condomínio, que deve contratar mão-de-obra especializada para operar o sistema e realizar o controle de qualidade da água não potável.

O Brasil ainda não possui uma norma referente à qualidade de água para a reutilização das águas cinzas. Neste empreendimento foi utilizado o padrão americano que, ao comparar com as demais publicações internacionais, é considerada a mais exigente. Além da inexistência da norma nacional, cabe ressaltar que não existe no país órgão público com a função de exigir as análises periódicas da qualidade da água tratada e manutenção periódica.

A carência de normalização nacional referente ao tema proporciona a utilização da tecnologia de forma insegura, submetendo os usuários ao consumo de água com características inadequadas e, conseqüentemente, com o risco de prejudicar a saúde.

- Separar horizontal e verticalmente as tubulações de água potável, não potável e de esgoto sanitário

O projeto apresenta separação física entre as tubulações dos diferentes sistemas prediais, porém não respeita o critério de distanciamento mínimo à favor da segurança do sistema de 
distribuição de água, seja ele potável ou não potável, proposto no item 3.3.1, e preconizado pela EPA.

Nenhuma tubulação de água não potável encontra-se enterrada. Elas são originadas na estação de tratamento instalada no subsolo e desta é encaminhada para o reservatório superior de forma aérea.

- Pintar a tubulação de água não potável na cor roxa e identificar através de programação visual a tubulação de água não potável a cada três metros

A programação visual foi realizada no empreendimento por meio de placas. Elas informam o tipo de efluente em função da cor da tubulação. Desta forma, a cor roxa corresponde ao sistema de água não potável. Além desta placa, existem as que alertam os usuários para os diferentes sistemas prediais de distribuição de água e de coleta de esgoto; e as que contêm: “Cuidado! Tubulação roxa água não potável”.

A tubulação de água não potável localizada no subsolo é pintada com tinta acrílica, na cor roxa. Além da pintura, existe nessa tubulação, próximo a válvula de gaveta, uma placa de identificação do tipo de água e área servida, conforme ilustrado nas Figura 5.16.
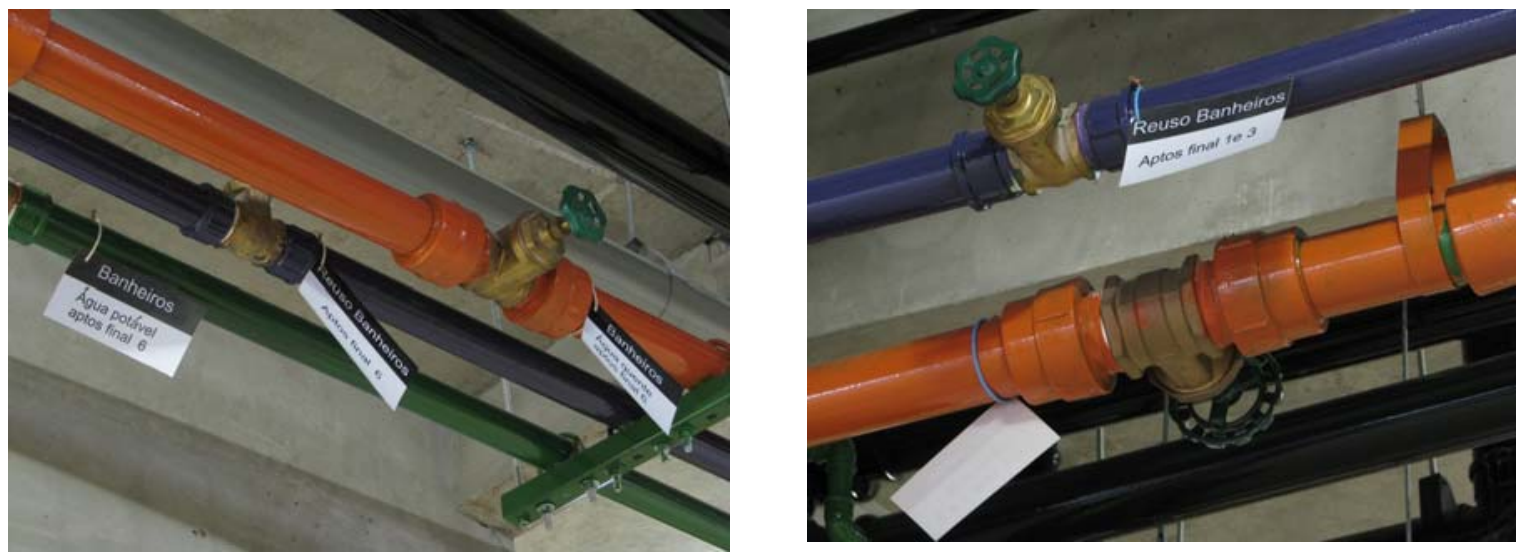

Figura 5.16 - Identificação nas tubulações adotada do empreendimento.

$\mathrm{Na}$ guarita do edifício existe uma placa, informando a necessidade de realizar análises laboratoriais para verificar a qualidade da água tratada. 
A programação visual adotada não proporciona segurança em todo o empreendimento. Caso necessite realizar manutenção nos ramais e shafts, bem como nos barriletes, não é possível identificar os diferentes sistemas. Esta situação pode proporcionar uma conexão cruzada indesejada entre os sistemas e colocar em risco a segurança da saúde dos usuários.

As visitas periódicas ao empreendimento permitiu identificar algumas placas descoladas das paredes do subsolo, em conseqüência do sistema de fixação adotado. Assim, sugere-se a fixação de placas por meio de parafusos com bucha.

\section{- Pigmentar o efluente tratado}

O edifício estudado não pigmenta diariamente a água não potável. A empresa contratada para operar a estação pigmenta apenas uma vez por mês essa água. Tal pigmentação é feita quando da realização do teste mensal para verificar a existência de conexão cruzada nas tubulações de água potável com a não potável.

O pigmento utilizado para a realização do teste é o azul de metileno. Segundo o responsável, após testar na sua residência, esse pigmento não originou manchas nas louças sanitárias. Em relação à quantidade de pigmento inserida no reservatório, ele afirma que deve ser no mínimo a capaz de colorir a água. A Figura 5.17 apresenta a aparência da água não potável pigmentada.

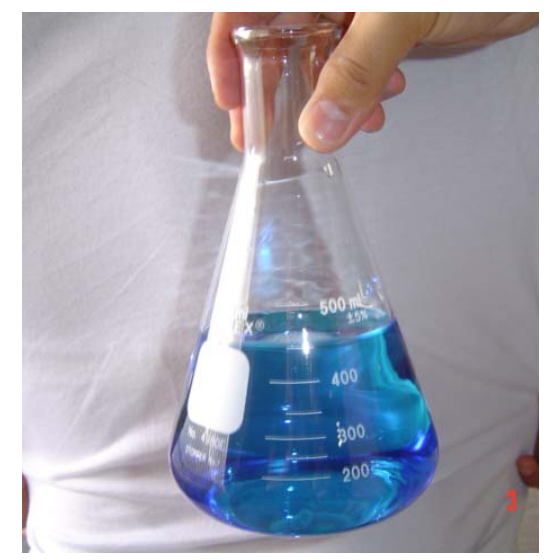

Figura 5.17 - Aparência da água não potável pigmentada com azul de metileno.

Um fabricante de pigmentos sugeriu a proporção de 0,1 grama de pigmento, laranja ou azul, em 100 mililitros de água. A fim de verificar a aparência da água pigmentada, optou-se por aplicar em laboratório as sugestões. A Figura 5.18 apresenta a aparência da água após a 
pigmentação. A cor azul, quando diluída em água, é mais vibrante que a laranja, o que favorece a percepção do usuário quando da ocorrência de conexão cruzada.
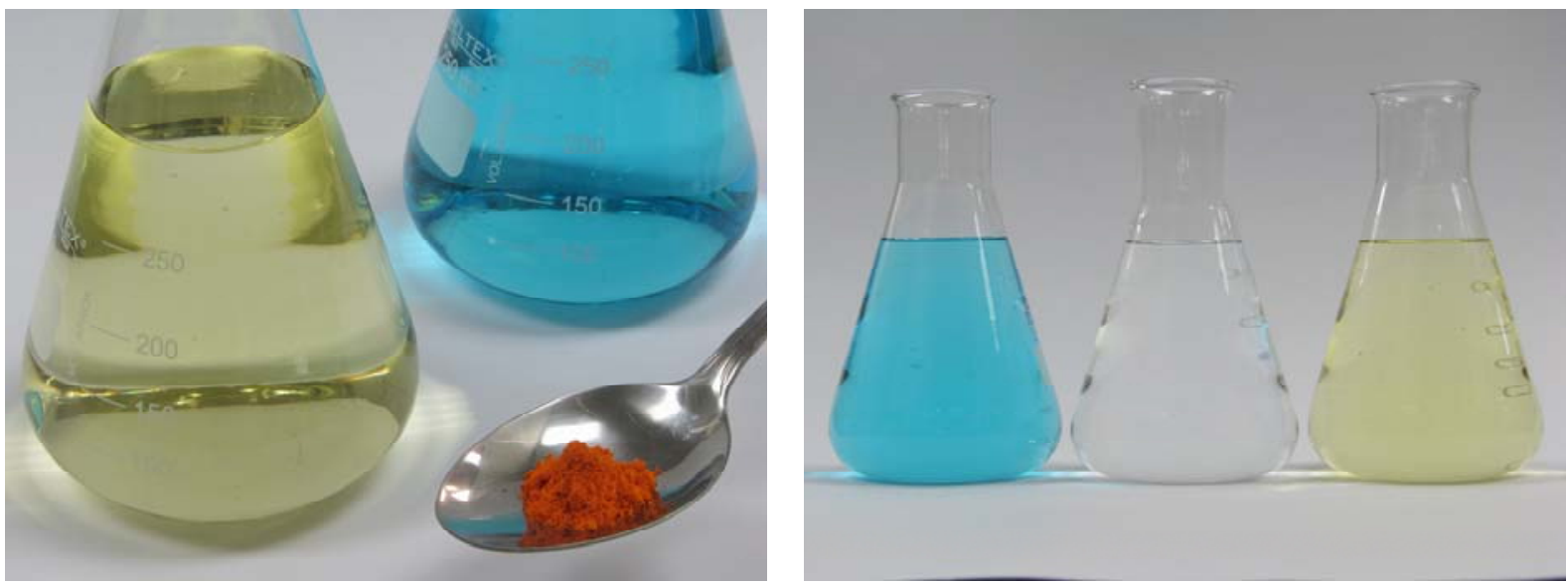

Figura 5.18- Aparência da água não potável pigmentada com a cor azul e laranja, conforme recomendação do fabricante.

A pigmentação da água não potável deve ser realizada diariamente para que a identificação da interligação indesejada entre os subsistemas de distribuição de água potável e não potável seja imediatamente detectada. Cabe ressaltar que, em relação ao tipo de pigmento utilizado, não se pode confirmar a adequação desse pigmento, tendo em vista que não foram realizados ensaios em laboratório certificado, com intuito de comprovar a inexistência de manchas em louça sanitária.

\section{- Utilizar material da tubulação de água não potável diferente da de água potável}

Os materiais das tubulações de água potável e não potável são os mesmos, o que facilita a interligação indesejada entre os subsistemas. O engenheiro responsável pela atividade de compras da construtora, afirma que o PVC, por ter custo aproximado de $1 / 3$ dos demais materiais, é o mais empregado, o que requer atenção para não interligar os sistemas de forma inadequada.

Como não houve treinamento da mão-de-obra há um maior risco de intercambialidade entre os subsistemas de distribuição de água potável e não potável. 


\section{- Elaboração de manual e guia de operação do sistema}

O contrato com o fornecedor da estação de tratamento inclui o manual do proprietário, que especifica a periodicidade de manutenção e os testes laboratoriais necessários para o controle da qualidade da água não potável.

A construtora, antes de "entregar" o empreendimento, realizou análises químicas, físicas e biológicas comprovando a eficiência do sistema de tratamento, bem como a inexistência de conexões cruzadas. Além disso, ela informou ao "condomínio", a necessidade em contratar mão-de-obra especializada para operar o sistema.

O projeto prevê a fonte alternativa de água potável, o que permite ao condomínio a flexibilidade em operar ou não o sistema de água não potável. Para o empreendimento estudado o fornecedor da estação de tratamento foi o mesmo contratado para operar com o custo mensal de $\mathrm{R} \$ 700,00$, ou seja, corresponde a um custo de $\mathrm{R} \$ 4,86$ por apartamento. Nesse contrato estão inclusas, além das análises laboratoriais, a realização de testes mensais para verificar a ocorrência de conexão cruzada.

É importante a iniciativa da construtora em comprovar a eficiência do sistema de tratamento, bem como, de indicar a necessidade de contratar mão-de-obra especializada para operar o sistema. A implantação do sistema de aproveitamento de água cinza no empreendimento consiste na "adoção" de uma nova fonte de água, em que o condomínio é o responsável pela gestão da qualidade da água entregue aos moradores. Portanto, é necessário que o sistema seja operado por especialistas e não consistir em mais uma das atividades do zelador.

\subsubsection{Requisito quantidade}

\section{- Prever a alimentação de água potável no sistema de água não potável}

O reservatório inferior recebe tubulação a partir do hidrômetro para suprimento em caso de falha no sistema de água não potável. Esta foi uma decisão da construtora, sem a participação do projetista de sistemas prediais e da projetista da estação de tratamento. Assim, a tubulação originada no hidrômetro alimenta o reservatório inferior de água potável e também o reservatório de água não potável. Essa tubulação dispõe de uma válvula de gaveta com a função de permitir ou não a entrada de água potável no reservatório. O mais adequado seria 
que a alimentação do reservatório de água não potável a partir do alimentador predial fosse automatizada.

Segundo a NBR 5626 (ABNT, 1998) item 5.4.3 a separação atmosférica é um modo que pode ser implantado a fim de evitar o refluxo. A referida norma recomenda a altura mínima da separação atmosférica em função do diâmetro do ramal de alimentação.

A localização dos reservatórios inferiores de água potável e não potável propiciou a comunicação entre esses reservatórios para alimentar o reservatório de água não potável, quando da manutenção da ETAC.

A alimentação do reservatório de água não potável, com água potável, ocorre por meio de uma tubulação $25 \mathrm{~mm}$ de diâmetro a partir do barrilete inferior que alimenta o reservatório de água potável. A água potável é conduzida ao reservatório de água não potável por meio de recalque automático composto por uma bomba de 0,5 HP quando o nível da água no reservatório de água não potável atinge o nível mínimo. A Figura 5.19 mostra a previsão entre os reservatórios inferiores.

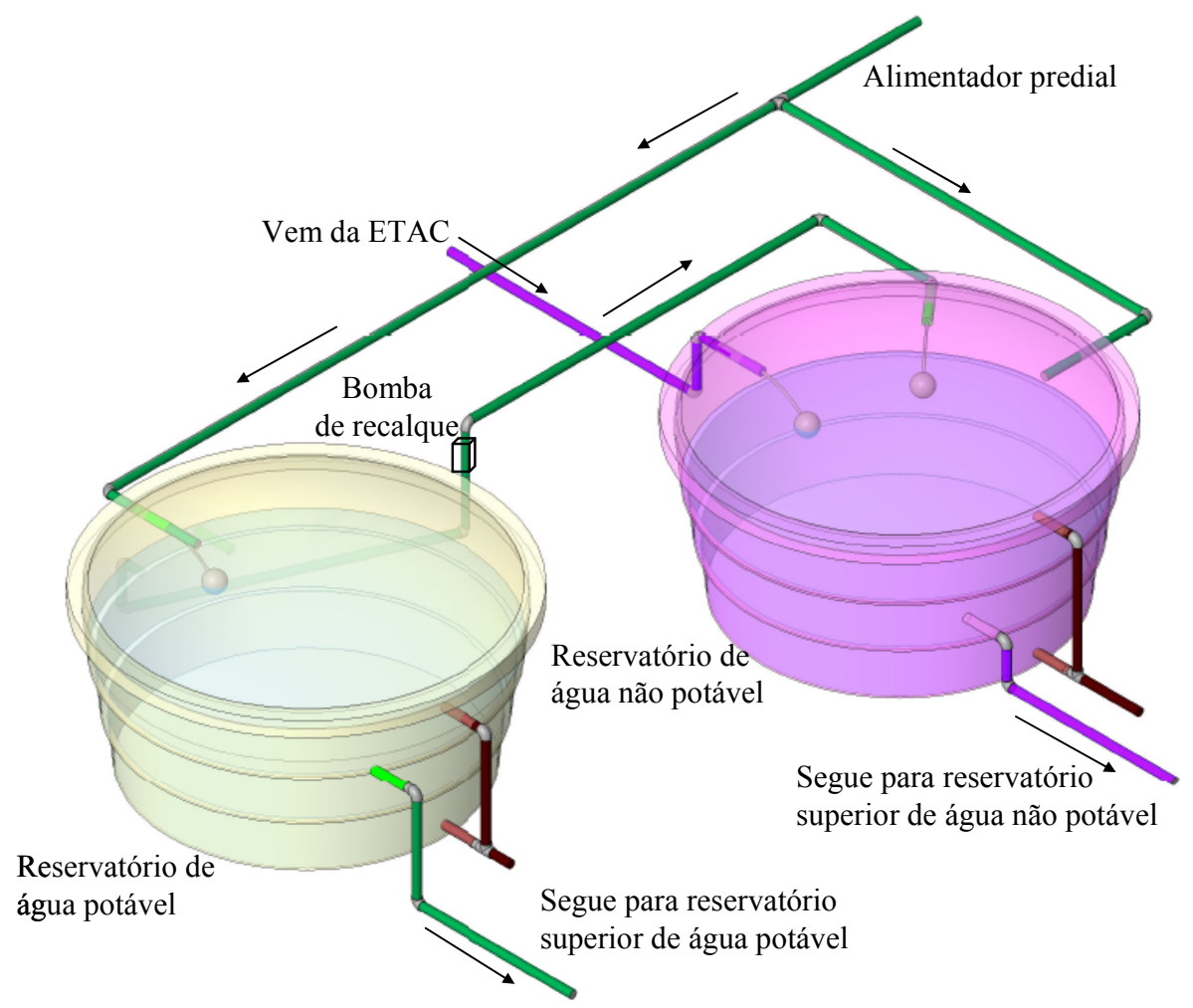

Figura 5.19 - A previsão da alimentação de água potável no reservatório de água não potável. 
A tubulação originada da bomba de recalque é encaminhada à face superior do reservatório de água não potável. A Figura 5.20 apresenta o detalhe do reservatório de água não potável. Observa-se que na face superior existem duas previsões de fontes de água potável: uma do alimentador predial e outra proveniente do barrilete inferior de água potável. As duas entradas de água potável à do extravasor, atendendo a altura mínima da separação atmosférica entre os sistemas potável e não potável, o que consiste em uma medida de segurança à saúde dos usuários.

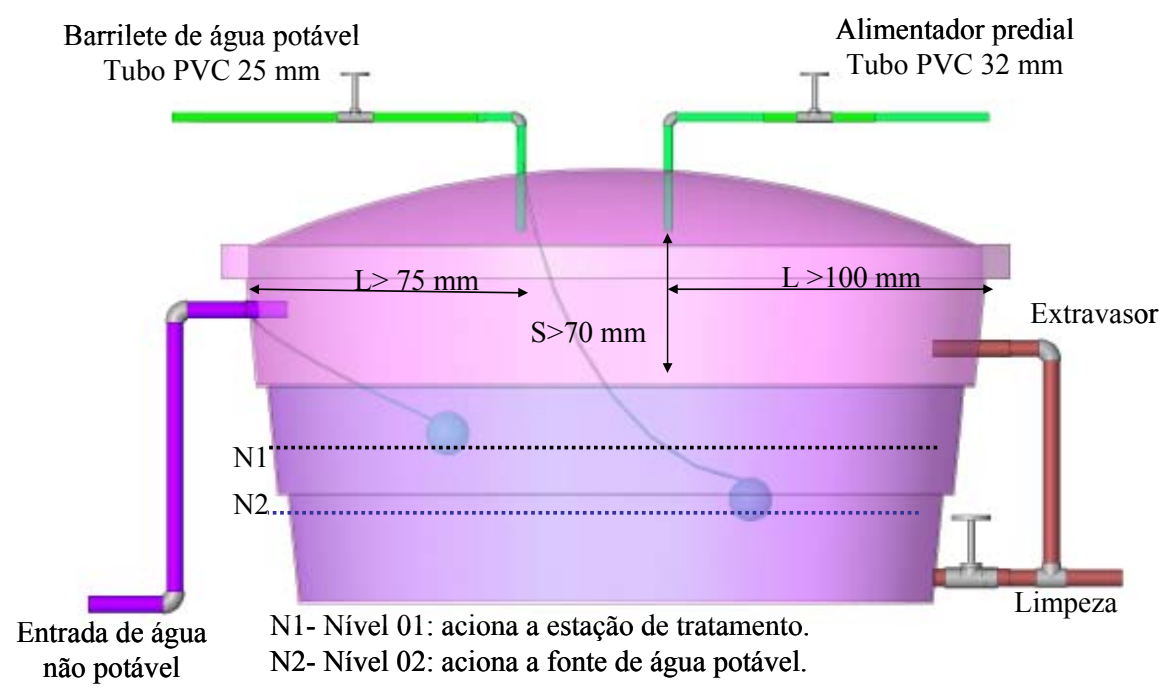

(a)

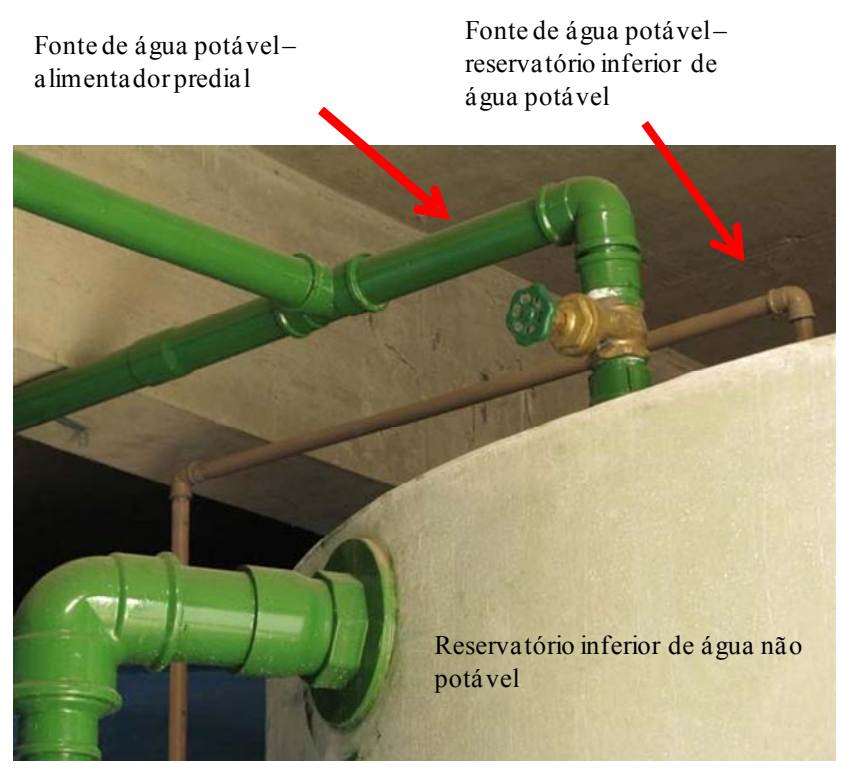

(b)

Figura 5.20 - Reservatório de água não potável e ramais de alimentação de água potável: (a) detalhe e (b) foto. 
Assim, existem dois ramais de alimentação de água potável. Um ramal ocorre a partir do hidrômetro e outro do barrilete que alimenta o reservatório de água potável. Considera-se para as duas situações, que a distância mínima entre a tubulação de água potável e o nível de água no reservatório de água não potável, estão respeitadas de acordo com a separação atmosférica recomendada pela NBR 5626 (ABNT, 1998) para evitar o refluxo.

Observa-se a inexistência da válvula anti-refluxo, no entanto o reservatório de água não potável apresenta a separação atmosférica maior do que a necessária.

A Tabela 5.6 apresenta o resumo da avaliação dos requisitos de desempenho atendidos para o sistema predial de água não potável.

Tabela 5.6 - Resumo do atendimento dos requisitos e critérios do sistema predial de água não potável.

\begin{tabular}{|c|c|c|c|c|}
\hline SISTEMA & ETAPA & $\begin{array}{l}\text { REQUISITO DE } \\
\text { DESEMPENHO }\end{array}$ & CRITÉRIOS & $\begin{array}{c}\text { Grau de } \\
\text { atendimento }\end{array}$ \\
\hline $\begin{array}{l}\mathbf{S} \\
\mathbf{I} \\
\mathbf{S}\end{array}$ & PROJETO & Quantidade & $\begin{array}{c}\text { Fazer a previsao de água potável } \\
\text { no reservatório de água não } \\
\text { potável. }\end{array}$ & SIM \\
\hline $\mathbf{T}$ & PROJETO & Qualidade & $\begin{array}{c}\text { Não utilizar materiais que reduza } \\
\text { a qualidade da água. }\end{array}$ & SIM \\
\hline $\begin{array}{l}\mathbf{M} \\
\mathbf{A} \\
\tilde{\mathbf{A}}\end{array}$ & MANUTENÇÃO & Qualidade & $\begin{array}{c}\text { Prever a monitoração periódica } \\
\text { da qualidade da água após a } \\
\text { ETAC. }\end{array}$ & SIM \\
\hline $\begin{array}{ll}\mathbf{P} & \mathbf{O} \\
\mathbf{R} & \\
\mathbf{E} & \mathbf{P}\end{array}$ & EXECUÇÃO & Operação & $\begin{array}{c}\text { Identificar, através de } \\
\text { programação visual nas } \\
\text { tubulações a cada } 3 \text { metros. }\end{array}$ & NÃO \\
\hline $\begin{array}{ll}\mathbf{D} & \mathbf{O} \\
\mathbf{I} & \mathbf{T} \\
\mathbf{A} & \mathbf{A}\end{array}$ & EXECUÇÃO & Operação & $\begin{array}{l}\text { Pintar o sistema de água não } \\
\text { potável na cor roxa. }\end{array}$ & $30 \%$ \\
\hline L V & EXECUÇÃO & Operação & Pigmentar o efluente tratado. & $10 \%$ \\
\hline $\begin{array}{l}\text { D } \mathbf{L} \\
\mathbf{E}\end{array}$ & $\begin{array}{l}\text { PROJETO/ } \\
\text { EXECUÇÃO }\end{array}$ & Operação & $\begin{array}{c}\text { Utilizar na tubulação de água de } \\
\text { não potável material diferente da } \\
\text { de água potável. }\end{array}$ & NÃO \\
\hline $\mathbf{U}$ & OPERAÇÃO & Operação & $\begin{array}{l}\text { Existência de guia de operação e } \\
\text { manutençao do sistema }\end{array}$ & SIM \\
\hline
\end{tabular}




\subsection{Análise do Modo e Efeito de Falha para esse projeto}

A aplicação da análise de modo e efeito de falha para o sistema predial de água não potável do edifício em estudo é iniciada com a verificação da utilização das ações essenciais, apresentadas na Tabela 4.6, Tabela 4.9 e Tabela 4.12, para cada requisito: qualidade, quantidade e conforto respectivamente.

\subsubsection{Requisito Qualidade}

Como apresentado no item 4.3.1 as atividades essenciais para o requisito qualidade encontram-se divididas em dois grupos, as necessárias para eliminar as falhas: 01, 0203 e 04 e outro grupo para evitar a falha 05,06 e 07.

A Tabela 5.7 apresenta a verificação das ações essenciais consideradas no edifício para eliminar a falha 01, 02, 03 e 04. Algumas atividades, como a identificação das tubulações e a pigmentação do efluente tratado não foram consideradas na sua totalidade, devido aos seguintes motivos descritos a seguir.

As únicas tubulações pintadas são as localizadas no subsolo e na casa de máquina do edifício, o que não corresponde à totalidade instalada. As colunas e ramais de distribuição, tanto de água como o de coleta de efluentes, não estão identificados e são consideradas locais aptos a ocorrência da conexão cruzada. Assim, não é possível garantir a inexistência da falha para esse requisito. Desta forma, foi considerado o valor de $30 \%$ representando a quantidade de tubulação instalada no subsolo e na casa de máquina em relação aos demais locais.

A pigmentação de água não potável como já apresentado, é realizada apenas uma vez por mês durante o teste de verificação da conexão cruzada, pela empresa especializada. A consideração de $10 \%$ foi uma estimativa, em que foi considerado que o pigmento permaneceria na água por um período máximo de três dias.

As ações essenciais realizadas no edifício possuem $100 \%$ de atendimento, para as que não são implantadas, $0 \%$. Os valores, considerados para as respectivas ações estão justificados de acordo com a análise realizada em cada subsistema de coleta de água cinza e de distribuição de água não potável, apresentadas nos itens 5.4, 5.5 e 5.6. 
Tabela 5.7 - Verificação das ações essenciais consideradas no edifício para o requisito qualidade.

\begin{tabular}{|c|c|}
\hline AÇÕES ESSENCIAIS & $\begin{array}{l}\text { Grau de } \\
\text { atendimento } \\
\text { da ação }\end{array}$ \\
\hline $\begin{array}{l}\text { - Utilização de materiais com diferentes características, de modo que impossibilite a } \\
\text { intercambialidade. }\end{array}$ & 0 \\
\hline - Pigmentação da água não potável. & 10 \\
\hline - Realização de programação visual do sistema. & 30 \\
\hline - Identificar o sistema antes da sua execução. & 0 \\
\hline - Testar o sistema para comprovar a separação das tubulações. & 100 \\
\hline - Informar a população, dos riscos da conexão cruzada. & 0 \\
\hline - Inspeção periódica do sistema executado. & 0 \\
\hline $\begin{array}{l}\text { - Registro em livro de ocorrência de mudanças e reformas comprovando a separação das } \\
\text { tubulações. }\end{array}$ & 0 \\
\hline $\begin{array}{l}\text { - Utilização de válvulas que evitam o retorno da água não potável no sistema de água } \\
\text { potável ou de separação atmosférica; }\end{array}$ & 100 \\
\hline - Manutenção da pressão positiva no sistema de água potável; & 100 \\
\hline - Realização de vistorias periódicas para detecção de vazamentos; & 100 \\
\hline $\begin{array}{l}\text { - Projetar sistemas respeitando o mínimo de separação entre as tubulações, de modo que } \\
\text { na ocorrência do vazamento, o efluente descartado não comprometa a segurança do outro } \\
\text { sistema. }\end{array}$ & 0 \\
\hline $\begin{array}{l}\text { - Monitorar periodicamente a qualidade da água tratada, conforme as diretrizes } \\
\text { publicadas na Tabela } 3.3 \text { ou 3.4. }\end{array}$ & SIM \\
\hline
\end{tabular}

A verificação apresentada permite concluir que não houve a totalidade da aplicação das ações essenciais sugeridas. Portanto considera-se que existe a possibilidade de ocorrer cada uma dessas falhas, independentemente.

O nível prioritário de risco é alto para as falhas 01, 03, 02 e 04, (Tabela 5.8) respectivamente. Cabe salientar que o efeito produzido no sistema com a ocorrência dessas falhas está relacionado diretamente com a saúde dos usuários, com o risco de distribuir água com condições inadequadas para o consumo. 
Tabela 5.8 - Falhas 01, 02, 03 e 04 com seus respectivos nível prioritário de risco (NPR).

\begin{tabular}{|l|l|}
\hline \multicolumn{1}{|c|}{ FALHA } & NIVEL PRIORITÁRIO DE RISCO \\
\hline \hline $\begin{array}{l}\text { FALHA 01 - Abastecimento de equipamentos sanitários com } \\
\text { água de qualidade inadequada. }\end{array}$ & $\mathrm{NPR}_{\text {Falha } 01}=(\mathrm{S}) 3 \times(\mathrm{O}) 3 \times \mathrm{D}(3)=27$ \\
\hline $\begin{array}{l}\text { FALHA 02 - Tratamento ineficiente do efluente, tendo em vista } \\
\text { que houve coleta de águas negras e não apenas das águas cinzas. }\end{array}$ & $\mathrm{NPR}_{\mathrm{Falha} 02}=(\mathrm{S}) 2 \times(\mathrm{O}) 3 \times(\mathrm{D}) 2=12$ \\
\hline $\begin{array}{l}\text { FALHA 03 - Contaminação do sistema de água potável e } \\
\text { fornecimento de água de não potável para todos os equipamentos } \\
\text { sanitários. }\end{array}$ & $\mathrm{NPR}_{\mathrm{Falha} 03}=(\mathrm{S}) 3 \times(\mathrm{O}) 3 \times \mathrm{D}(3)=27$ \\
\hline $\begin{array}{l}\text { FALHA 04 - Infiltração da água de menor qualidade, proveniente } \\
\text { do vazamento, no sistema que contém água de melhor qualidade. }\end{array}$ & $\mathrm{NPR}_{\text {Falha } 04}=(\mathrm{S}) 3 \times(\mathrm{O}) 1 \times(\mathrm{D}) 3=9$ \\
\hline
\end{tabular}

Além dessas falhas passíveis de ocorrência no requisito qualidade, ainda podem ocorrer as 05 , 06 e 07, cujas ações essenciais estão apresentadas na Tabela 5.9. De acordo com esta tabela, apenas a utilização de materiais em conformidade com a norma não obteve a totalidade do grau de atendimento da ação. A carência de dados dos fabricantes impossibilitou a conclusão dessa análise. Como já apresentado, os componentes da ETAC não possuem laudos de qualidade publicados. Como os materiais utilizados na tubulação e reservatórios, estão em conformidade com as respectivas normas técnicas, foi considerado $100 \%$ de atendimento.

Tabela 5.9 - Ações essenciais para as falhas 05, 06 e 07.

\begin{tabular}{|l|c|}
\hline \multicolumn{1}{|c|}{ AÇÕES ESSENCIAIS } & $\begin{array}{c}\text { Grau de } \\
\text { atendimento da } \\
\text { ação }\end{array}$ \\
\hline - Utilizar materiais em conformidade com a norma técnica. & 100 \\
\hline - Contratar mão-de-obra especializada para operar. & 100 \\
\hline $\begin{array}{l}\text { • } \\
\text { 3.4. }\end{array}$ & 100 \\
\hline
\end{tabular}

Os dados apresentados permitem concluir que todas as ações essenciais previstas para as especificadas falhas 05, 06 e 07 (Tabela 5.10) foram executadas no edifício em estudo, eximindo assim o risco de prejudicar a saúde dos usuários. 
Tabela 5.10 - Falhas 05, 06, e 07 com seus respectivos nível prioritário de risco (NPR).

\begin{tabular}{|l|l|}
\hline \multicolumn{1}{|c|}{ FALHA } & NIVEL PRIORITÁRIO DE RISCO \\
\hline \hline $\begin{array}{l}\text { FALHA 05 - Penetração da luz e favorecimento do crescimento } \\
\text { de algas e conseqüentemente contaminando a água armazenada. }\end{array}$ & $\mathrm{NPR}_{\text {Falha } 05}=(\mathrm{S}) 2 \times(\mathrm{O}) 1 \times(\mathrm{D}) 3=6$ \\
\hline $\begin{array}{l}\text { FALHA 06 - Degradação do material e comprometimento da } \\
\text { qualidade da água armazenada. }\end{array}$ & $\mathrm{NPR}_{\text {Falha } 06}=(\mathrm{S}) 2 \times(\mathrm{O}) 1 \times(\mathrm{D}) 3=6$ \\
\hline FALHA 07 - Colocar em risco a saúde dos usuários. & $\mathrm{NPR}_{\text {Falha } 07}=(\mathrm{S}) 3 \times(\mathrm{O}) 3 \times \mathrm{D}(3)=27$ \\
\hline
\end{tabular}

As ações essenciais exigidas para evitar a falha do atendimento do requisito qualidade não foram todas executadas no edifício, o que pode ser considerado um problema grave, tendo em vista que qualquer deslize comprometa o desempenho do sistema e colocar em risco a saúde dos usuários.

O próximo item apresenta a hierarquização das ações essenciais para o requisito qualidade. Nele consta a verificação de cada atividade considerada e finaliza apresentando a sugestão para aumentar a confiabilidade do sistema.

\subsubsection{Análise das ações essenciais do requisito qualidade no edifício}

O item 4.4 abordou questões referentes à hierarquização das atividades essenciais para o requisito qualidade, tendo em vista ser considerado neste trabalho como o requisito mais importante dentre os demais. Assim, neste item é realizada uma avaliação do atendimento das ações essenciais propostas no edifício em análise.

A Tabela 5.11 apresenta todas as ações essenciais e a respectiva fase projeto, execução e manutenção em que deve ser inserida cada ação. Nesta tabela constam os valores elaborados para cada ação e o valor da ação considerada no edifício. Com base nesses valores foi possível obter o índice de atendimento das ações em relação à proposta. 
Tabela 5.11 - Valores das ações essenciais do requisito qualidade para as fases projeto (P), execução (E) e manutenção (M) do edifício.

\begin{tabular}{|c|c|c|c|c|c|}
\hline Ação Essencial & Fase & GI* & $\begin{array}{c}\text { Índice } \\
\text { da } \\
\text { fase** }\end{array}$ & $\begin{array}{c}\text { Valor } \\
\text { da ação }\end{array}$ & $\begin{array}{c}\text { Grau de } \\
\text { atendimento }\end{array}$ \\
\hline $\begin{array}{l}\text { - Verificar a instalação de válvulas que evitam o retorno } \\
\text { da água não potável ou a existência da separação } \\
\text { atmosférica entre os sistemas de água potável e não } \\
\text { potável. }\end{array}$ & $\mathrm{P}$ & 5 & 9 & 45 & SIM \\
\hline $\begin{array}{l}\text { - Utilizar materiais com diferentes características, de } \\
\text { modo que impossibilite a sua interligação. }\end{array}$ & $\mathrm{P}$ & 4 & 9 & 36 & NÃO \\
\hline - Manter a pressão positiva no sistema de água potável. & $\mathrm{P}$ & 3 & 9 & 27 & SIM \\
\hline \multirow{2}{*}{$\begin{array}{l}\text { - Projetar sistemas respeitando o mínimo de separação } \\
\text { entre as tubulações, de modo que na ocorrência do } \\
\text { vazamento, o efluente descartado não comprometa a } \\
\text { segurança do outro sistema. }\end{array}$} & $\mathrm{P}$ & 2 & 9 & 18 & NÃO \\
\hline & \multicolumn{4}{|c|}{ TOTAL FASE PROJETO = 126} & $(45+27)=72$ \\
\hline \multicolumn{5}{|c|}{ \% das ações essenciais atendidas na fase projeto do edifício } & $57 \%$ \\
\hline - Capacitar a mão-de-obra. & \multirow{2}{*}{$\mathrm{E}$} & 3 & 6 & 18 & NÃO \\
\hline \multirow[t]{2}{*}{ - Identificar as tubulações antes da execução. } & & 3 & 6 & 18 & NÃO \\
\hline & \multicolumn{4}{|c|}{ TOTAL FASE EXECUÇÃO = 36} & $\mathbf{0}$ \\
\hline \multicolumn{5}{|c|}{ \% das ações essenciais atendidas na fase execução do edifício } & $\mathbf{0 \%}$ \\
\hline \multicolumn{6}{|c|}{\begin{tabular}{|l|l|l|l|l|l|l|} 
- Contratar mão-de-obra especializada para operar a & M & 5 & 6 & 30 & SIM \\
estação de tratamento.
\end{tabular}} \\
\hline $\begin{array}{l}\text { - Registrar as reformas nas tubulações e comprovar a } \\
\text { separação das tubulações. }\end{array}$ & M & 3 & 1 & 3 & NÃO \\
\hline - Realizar a pigmentação diária do efluente tratado. & $\mathrm{M}$ & 3 & 1 & 3 & $10 \%$ \\
\hline $\begin{array}{l}\text { - Educar a população, abordando a importância da } \\
\text { qualidade da água. }\end{array}$ & M & 3 & 1 & 3 & NÃO \\
\hline \multirow{2}{*}{$\begin{array}{l}\text { - Providenciar a pintura da tubulação anualmente. } \\
\text { - Realizar teste na tubulação mensalmente, comprovando } \\
\text { a separação da tubulação. }\end{array}$} & $\mathrm{M}$ & 2 & 1 & 2 & NÃO \\
\hline & M & 3 & 1 & 3 & SIM \\
\hline \multirow{2}{*}{$\begin{array}{l}\text { - Verificação mensal da separação da tubulação. } \\
\text { - Realizar vistorias periodicamente para detecção de } \\
\text { vazamentos. }\end{array}$} & $\mathrm{M}$ & 2 & 1 & 2 & SIM \\
\hline & M & 2 & 1 & 2 & NÃO \\
\hline $\begin{array}{l}\text { - Monitorar periodicamente a qualidade da água tratada, } \\
\text { conforme a tabela } 3.3 \text { ou } 3.4 \text {. }\end{array}$ & M & 5 & 1 & 5 & SIM \\
\hline \multicolumn{5}{|c|}{ TOTAL FASE MANUTENÇÃO = 53} & $\begin{array}{l}(30+0,3+3+2 \\
+5)=40,3 \\
\end{array}$ \\
\hline \multicolumn{5}{|c|}{ \% das ações essenciais atendidas na fase manutenção do edifício } & $76 \%$ \\
\hline
\end{tabular}

* GI corresponde ao grau de importância para cada ação essencial no sistema, varia de 1 a 5 , conforme a Tabela 4.14.

** Valor estabelecido para fase projeto (9), execução (6) e manutenção (1). 
Para a fase projeto houve $57 \%$ de atendimento das ações essenciais propostas enquanto que para execução não houve atendimento e para a atividade de manutenção obteve $76 \%$ das ações essenciais recomendadas.

Como apresentado não foi realizada nenhuma atividade essencial proposta para a atividade de execução. A inexistência dessas ações é considerada uma falha grave e como apresentado na avaliação do atendimento dos requisitos propostos no início deste capítulo, houve problema de conexão cruzada entre os sistemas prediais de coleta de água cinza e negra durante essa fase de execução. O ocorrido comprova a importância em considerar as ações e conseqüentemente em atender o requisito qualidade.

\subsubsection{Requisito quantidade}

O requisito quantidade necessita de duas ações essenciais para evitar a ocorrência de falhas. Para o sistema estudado considera instalada a fonte de água potável no reservatório de água não potável para distribuir água potável às bacias sanitárias, durante o período de manutenção da estação de tratamento, ou na ocasião em que o volume disponível de água não potável for inferior ao demandado pelas bacias. De acordo com a análise crítica do projeto, existem duas modalidades de previsão, a originada da rede pública e a interligada com o barrilete inferior de água potável.

A outra ação também considerada para o requisito é a utilização das reais vazões de efluentes para o dimensionamento do sistema. A sua utilização, na consideração do equilíbrio entre o volume demandado, pelas descargas das bacias e o ofertado, pelo lavatório e chuveiro permite projetar estações de tratamento mais otimizadas. Como já foi apresentado, no edifício em estudo não houve a referida análise entre os volumes, o que resultou no projeto da estação com capacidade de tratamento de todo o volume ofertado (Tabela 5.12).

Tabela 5.12 - Ações essenciais para as falhas do requisito quantidade.

\begin{tabular}{|l|c|}
\hline \multicolumn{1}{|c|}{ AÇÕES ESSENCIAIS } & $\begin{array}{c}\text { Grau de } \\
\text { atendimento da } \\
\text { ação }\end{array}$ \\
\hline $\begin{array}{l}\text { • Implantar no projeto a opção de comunicação entre reservatórios de água potável e } \\
\text { não potável, ou a partir do hidrômetro. }\end{array}$ & 100 \\
\hline$\bullet \quad$ Dimensionar o sistema utilizando as reais vazões dos efluentes. & 0 \\
\hline
\end{tabular}


As falhas possíveis de ocorrer no requisito quantidade estão apresentadas na Tabela 5.13. De acordo com o exposto, existe o risco de ocorrer a falha 03 , no edifício em estudo, que consiste na falha que possui maior risco em relação as demais.

Tabela 5.13 - As falhas com seus respectivos nível prioritário de risco (NPR) para o requisito quantidade.

\begin{tabular}{|l|l|}
\hline \hline \multicolumn{1}{|c|}{ FALHA } & NIVEL PRIORITÁRIO DE RISCO \\
\hline $\begin{array}{l}\text { FALHA 01 - Falta de água devido à coleta de menor volume do } \\
\text { que o necessário. }\end{array}$ & $\mathrm{NPR}_{\text {Falha 05 }}=(\mathrm{S} 3 \times(\mathrm{O}) 2 \times(\mathrm{D}) 1=6$ \\
\hline $\begin{array}{l}\text { FALHA 02 - Falta de água devido às atividades de manutenção da } \\
\text { estação de tratamento. }\end{array}$ & $\mathrm{NPR}_{\text {Falha 06 }}=(\mathrm{S}) 3 \times(\mathrm{O}) 1 \times(\mathrm{D}) 1=3$ \\
\hline $\begin{array}{l}\text { FALHA 03 - Superdimensionamento das estações de tratamento, } \\
\text { necessitando de maiores áreas para instalação, aumentando o a } \\
\text { viabilidade técnica e econômica. }\end{array}$ & $\mathrm{NPR}_{\text {Falha 07 }}=(\mathrm{S}) 3 \times(\mathrm{O}) 3 \times \mathrm{D}(1)=9$ \\
\hline
\end{tabular}

\subsubsection{Requisito conforto}

$\mathrm{O}$ requisito conforto é considerado os referentes à disponibilidade, acessibilidade e adequabilidade. Como apresentada na Tabela 5.14, todas as ações essenciais necessárias para esse requisito foram consideradas, eximindo assim a existência das falhas listadas na Tabela 5.15 .

Tabela 5.14 - Verificação das ações essenciais consideradas no edifício para o requisito conforto.

\begin{tabular}{|l|c|}
\hline \multicolumn{1}{|c|}{ AÇÕES ESSENCIAIS } & $\begin{array}{c}\text { Grau de } \\
\text { atendimento da } \\
\text { ação \% }\end{array}$ \\
\hline $\begin{array}{l}\text { - Utilizar válvula de gaveta apropriada para o sistema de esgoto, com a função de } \\
\text { descartar o efluente na rede de esgoto antes da estação de tratamento quando } \\
\text { necessário. }\end{array}$ & 100 \\
\hline $\begin{array}{l}\text { - Instalar materiais que possibilite acesso na tubulação de esgoto para inspeção a } \\
\text { cada 15 m, caso exista curva de 90 a inspeção deve ser após 1,5 m. }\end{array}$ & 100 \\
\hline - Possuir diâmetro interno na tubulação no mínimo de 75 mm. & 100 \\
\hline - Considerar em projeto as recomendações da NBR 5626 (ABNT, 1998).. & 100 \\
\hline
\end{tabular}


Tabela 5.15 - As falhas com seus respectivos níveis prioritários de risco (NPR) para o requisito conforto.

\begin{tabular}{|l|l|}
\hline \multicolumn{1}{|c|}{ FALHA } & NIVEL PRIORITÁRIO DE RISCO \\
\hline \hline FALHA 01 - Gera mau cheiro e prolifera vetores no ambiente. & $\mathrm{NPR}_{\text {Falha } 01}=(\mathrm{S} 3 \times \mathrm{O}(\mathrm{O}) 3 \times(\mathrm{D}) 2=18$ \\
\hline $\begin{array}{l}\text { FALHA 02 - Danificação da tubulação para identificar o local da } \\
\text { obstrução. }\end{array}$ & $\mathrm{NPR}_{\text {Falha } 02}=(\mathrm{S}) 2 \times(\mathrm{O}) 2 \times(\mathrm{D}) 3=12$ \\
\hline $\begin{array}{l}\text { FALHA 03 - Comprometimento do escoamento do efluente no } \\
\text { interior da tubulação, ocasionando a obstrução. }\end{array}$ & $\mathrm{NPR}_{\text {Falha } 03}=(\mathrm{S}) 3 \times(\mathrm{O}) 3 \times \mathrm{D}(3)=27$ \\
\hline FALHA 04 - Transbordamento do efluente no meio ambiente. & $\mathrm{NPR}_{\text {Falha } 04}=(\mathrm{S}) 3 \times(\mathrm{O}) 3 \times \mathrm{D}(1)=9$ \\
\hline FALHA 05 - Dificuldade na remoção do efluente indesejado. & $\mathrm{NPR}_{\text {Falha } 05}=(\mathrm{S}) 2 \times(\mathrm{O}) 2 \times \mathrm{D}(1)=4$ \\
\hline
\end{tabular}

As análises de modo e efeito de falha realizadas para cada requisito permite inferir que o requisito qualidade corresponde ao mais crítico dentre os apresentados. A inexistência de ações essenciais compromete o desempenho para esse requisito e conseqüentemente para todo o sistema. Como já abordado anteriormente, a existência de apenas algumas ações essenciais não extingue a possibilidade de risco de prejudicar a saúde dos usuários, pois a atividade de intervenção no sistema pode ocorrer momentaneamente e, conseqüentemente, encadear a conexão cruzada. 


\section{CONCLUSÕES}

O trabalho foi desenvolvido com o principal objetivo de alertar os envolvidos no sistema predial de água não potável sobre a importância da consideração da abordagem desempenho. De acordo com o apresentado no trabalho, conclui-se que a saúde dos usuários pode ser colocada em risco nas fases de projeto, execução e manutenção do sistema predial de água não potável. Além disso, o trabalho permitiu concluir os seguintes itens.

- A utilização dos requisitos e critérios de desempenho desenvolvidos para esse sistema auxilia projetistas, executores e gestores do sistema de água não potável. No desenvolvimento de suas atividades tendo em vista que a complexidade dos sistemas de água não potável dificulta a utilização de normas prescritivas. Assim, os critérios foram desenvolvidos com as informações necessárias para atender o requisito proposto e, conseqüentemente, aplicar a abordagem de desempenho.

- A utilização da ferramenta de análise de modo e efeito de falha (FMEA) contribui para hierarquizar as prováveis falhas do sistema. O nível prioritário de risco (NPR) associado a cada falha auxilia os projetistas, executores e gestores na tomada de decisão das ações a serem consideradas em todas as fases no sistema predial de água não potável, possibilitando a escolha do nível de desempenho do sistema.

- A avaliação da aplicabilidade dos requisitos e critérios de desempenho no edifício estudado contribuiu para confirmar a praticidade da sua utilização.

- A aplicação da ferramenta FMEA no edifício possibilitou a identificação de falhas que ocorreram no sistema predial de água não potável implantado e a relação delas com as ações essenciais implantadas no edifício. Permitiu ainda observar que as falhas no sistema ocorreram pela ausência de ações essenciais recomendadas para cada requisito.

- A primeira falha identificada com, NPR 12, pela FMEA no edifício estudado foi relacionada ao requisito qualidade no que diz respeito ao tratamento ineficiente da água cinza. Esta falha teve como causa uma conexão cruzada nos desvios das prumadas de água cinza e negra possibilitando a condução de águas negras para a 
estação de tratamento de águas cinzas. A intercambialidade dos sistemas ocorreu devido a semelhança dos materiais das tubulações, falta de capacitação da mão-deobra, fiscalização do serviço executado.

- Outra falha, com NPR 9, identificada pela FMEA foi o superdimensionamento da estação de tratamento de águas cinzas, tendo como causa a coleta e tratamento de maior volume de efluente do que o necessário. O superdimensionamento ocorreu porque a ETAC não foi dimensionada de acordo com a demanda das bacias sanitárias.

A implantação da fonte alternativa de água é realmente uma importante ação de conservação da água, entende-se que esta solução em edifícios residenciais deva ser implementada somente após esgotadas todas as ações possíveis de uso racional da água.

O trabalho constatou que a implantação da fonte alternativa de água pode ser aplicada em edifícios residenciais desde que respeitados os critérios de projeto, execução e de manutenção do sistema predial de água, e que implante a gestão da água, eliminando a possibilidade de risco de contaminação e preserve a saúde dos usuários.

A implantação da fonte alternativa de água interfere diretamente em outros sistemas prediais, em regulamentações públicas, em capacitação técnica, normas regulamentadoras, hábitos dos usuários, fabricação de elementos, etc, considerando assim, a existência de vários pontos críticos.

Como recomendações para minimizar os pontos críticos do sistema, sugere-se:

- participação de fabricantes de estações de tratamento de águas cinzas em programas setoriais da qualidade do PBQP-H;

- fabricar tubulações na cor roxa, para aplicação no sistema predial de distribuição de água não potável e na cor cinza para o sistema predial de coleta de águas cinzas;

- criar órgãos federais, estaduais e municipais, para fiscalizar a operação dos sistemas de fonte alternativa de água implantados em edifícios;

- disponibilizar núcleos de capacitação da mão-de-obra destinada a executar o sistema predial de água não potável; 
- sensibilizar os usuários da importância da aplicação da gestão da água no edifício.

Como recomendações para trabalhos acadêmicos sugere-se:

- pesquisas para obtenção de dados de consumo de água por equipamento sanitário;

- validar a aplicação da ferramenta de análise de modo e efeito de falha em edifícios.

- pesquisas para obtenção de NPR por meio de outros índices atribuídos a severidade, ocorrência e deteç̧ão da falha como forma de ampliar a aplicação da ferramenta FMEA;

- hierarquizar todas as ações essenciais sugeridas para outros requisitos de desempenho propostos, tendo como referência as apresentadas no requisito qualidade. 


\section{REFERÊNCIAS BIBLIOGRÁFICAS}

ACTA. Interim Plumbing Requirements Greywater Reuse System Act. 2004. Disponível em: $<$ http://www.actpla.act.gov.au/bepcon/plumb/greywater.pdf $>$. Acesso: em fevereiro 2005.

AGUIAR, L. Metodologias de Análise de Riscos APP \& HAZOP. Rio de Janeiro 29p. Disponível em: <www.saneamento.poli.ufrj.br/documentos/Josimar/APP_e_HAZOP.pdf $>$. Acesso: agosto 2008.

AMORIM, S. Metodologia para estruturação do sistema de informação para projeto de sistemas hidráulicos prediais. 1997. 213p. Tese (doutorado). Escola Politécnica da Universidade de São Paulo, São Paulo, 1997.

ASSOCIAÇÃO BRASILEIRA DE NORMAS TÉCNICAS. NBR 5626 - Instalação predial de água fria, 1998.41p. Rio de janeiro.

ASSOCIAÇÃO BRASILEIRA DE NORMAS TÉCNICAS. NBR 6493 - Emprego de cores para identificação de tubulações, 1994. Rio de janeiro.

ASSOCIAÇÃO BRASILEIRA DE NORMAS TÉCNICAS. NBR 8160 - Sistemas prediais de esgoto sanitário, 1999.74p. Rio de janeiro.

ASSOCIAÇÃO BRASILEIRA DE NORMAS TÉCNICAS. NBR 15575-1 - Edifícios habitacionais de até cinco pavimentos - Desempenho - Parte 1: Requisitos gerais, 2008.44p. Rio de janeiro.

BRASIL. Ministério da saúde. Portaria N. 518 de 25 de março de 2004. Disponível em: $<$ http://dtr2001.saude.gov.br/sas/PORTARIAS/Port2004/GM/GM-518.htm>. Acesso em: setembro 2006.

BUILDING SERVICE RESEARCH AND INFORMATION ASSOCIATION. Water Reclamation Guidance. Design and Construction of systems using grey water. Technicall note TN 6/2002. Reino Unido, 2002. 5p. Disponível em <http://bsria.co.uk/bookshop $>$. Acesso: março de 2006.

CAMACHO, E. Uma proposta de metodologia para análise quantitativa de riscos Ambientais. 2004. Dissertação (mestrado). Universidade Federal do Rio de Janeiro. Rio de janeiro, 2004. 
CHENG, C; HO, K; YEN, C. Decision-making and assessment tool for current design of high-rise building drainage system in Taiwan. In: INTERNATIONAL SYMPOSIUM ON WATER SUPPLY AND DRAINAGE FOR BUILDINGS. CIB-W62. SEMINAR, Bruxelas, 2005.13p.

EPA VICTORIA. Delivering sustainable urban water recycling - an environmental regulator's perspective of dual pipe networks. In: ANNUAL WATER INDUSTRY ENGINEERS AND OPERATORS' CONFERENCE SPORTS AND LEISURE CENTRE. n. 67, 2004, Wodonga. Disponível em: $<$ http://www.wioa.org.au/conf_papers/2004/pdf/10wioa2004.pdf.> Acesso: fevereiro de 2006.

ENVIRONMENTAL PROTECTION AGENCY. Manual: Guidelines for water reuse. 1992. Washington: 2004. (EPA/ 625/R-92-004) Disponivel: $<$ http://www.epa.gov/nrmrl/pubs/625r04108/625r04108.pdf $>$. Acesso: fevereiro de 2005.

ENVIRONMENTAL PROTECTION AGENCY. Hazard Analysis Critical Control Point (HACCP) Strategies for Distribution System Monitoring, Hazard Assessment and Control. Washington, $2006 . \quad 81 \mathrm{p}$ Disponível em: $<$ http://www.epa.gov/safewater/disinfection/tcr/pdfs/issuepaper_tcr_haccp-strategies.pdf $>$ Acesso: junho de 2007.

ENVIRONMENTAL PROTECTION AGENCY. Cross Connection Control Manual. Estados Unidos, 2003. 52p. Disponível em: $<$ http://www.epa.gov/safewater/pdfs/crossconnection/crossconnection.pdf $>$. Acessado em: abril de 2007.

FERNANDES, V. Formulação das condições limites para utilização de ventilação primária e secundária nos sistemas prediais de esgotos sanitários de edifícios residenciais e de escritórios. 2002. 2V. Tese (doutorado). Escola Politécnica da Universidade de São Paulo, São Paulo, 2002.

GEORGIA DEPARTMANT OF NATURAL RESOURCE. Guidelines for water reclamation and urban water reuse. Georgia, 2002. 26p. Disponível em: $<$ http://www.gaepd.org/Files_PDF/techguide/wpb/reuse.pdf $>$. Acesso: março de 2006.

GRAÇA; GONÇALVES, O. Desempenho de sistemas sanitários prediais: conceitos fundamentais Revista de Engenharia Mackenzie São Paulo, v.70, n.177, p.7-13, jan./fev. 1986. 
GONÇALVES, O. Contribuições para a economia e qualidade dos sistemas prediais: texto que sistematiza criticamente a obra do autor. 1997. $48 \mathrm{p}+$ anexos. Tese de livre docência. Escola Politécnica da Universidade de São Paulo, São Paulo, 1997.

GONÇALVES, O. M. Racionalização sistêmica. Construção, Editora PINI, nº 321, p 36 e 37. Fev, 2000.

GONÇALVES, O. Conceito de Sistemas Prediais. São Paulo: Escola Politécnica da Universidade de São Paulo, marco de 2002. Notas de aulas da disciplina de pós graduação do Departamento de Construção civil, PCC 5715 - Qualidade dos Sistemas Prediais.

GRAÇA, M. Formulação de modelo para avaliação das condições determinantes da necessidade de ventilação secundaria em sistemas prediais de coleta de esgotos sanitários. 1985. 357 p. Tese (doutorado) - Escola Politécnica da Universidade de São Paulo, São Paulo, 1985.

HENZE, M.; LEDIN, A. Types, characteristics and quantities of classic, combined domestic wastewaters. New York: IWA Published, 2001.

HESPANHOL, I; TUCCI, C. Cenários da gestão da água no Brasil: uma contribuição para a “Visão Mundial da Água”. 2006. Disponível em: $<$ http://www.sei.ba.gov.br/publicacoes/publicacoes_sei/bahia_analise/analise_dados/pdf/recur sos_hidricos/pag_357.pdf>. Acesso em out. 2006.

JACK, I; SWAFFIELD, J; FILSELL, S. Identification of possible cross contamination scenarios facilitated by building drainage and ventilation systems, and the contributory role of modeling positive transient pressure propagation. In: INTERNATIONAL SYMPOSIUM ON WATER SUPPLY AND DRAINAGE FOR BUILDINGS. CIB W62.SEMINAR, Bruxelas, 2005. 13p.

KALBUSCH, A. Critérios de avaliação de sustentabilidade ambiental dos sistemas prediais hidráulicos e sanitários em edifícios de escritórios. 2006. 140p + anexos. Dissertação (mestrado). Escola Politécnica da Universidade de São Paulo, São Paulo 2006.

LAVRADOR, J. Contribuição para o entendimento do reúso planejado da água e algumas considerações sobre suas possibilidades no Brasil. 1987. 198p. Dissertação (mestrado). Escola Politécnica da Universidade de São Paulo. São Paulo, 1987.

MASINI, H. Avaliação do uso de válvulas de admissão de ar em substituição ao subsistema de ventilação convencional em sistemas prediais de esgotos sanitários. 1999. 
151p. Dissertação (mestrado). Escola Politécnica da Universidade de São Paulo, São Paulo, 1999.

METCALF \& EDDY. Wastewater Engineering. Treatment, disposal and reuse. 3. Ed. Boston: Mc Graw Hill, 1991. 1334p.

MIERZWA, J. O uso racional e o reúso como ferramentas para o gerenciamento de águas e efluentes na indústria : estudo de caso da KODAK Brasileira. 2002. 2v. Tese (doutorado). Escola Politécnica da Universidade de São Paulo, São Paulo, 2002.

NOLDE, E. Greywater reuse systems for toilet flushing in multi-storey buildings - over ten years experience in Berlin. Elsevier science. Urban water. pp.275-284, 1999.

NEW SOUTH WALES Guidelines for Sewered Residential Premises (Single Households) Greywater Reuse - Draft for Comment. Austrália, 2002. 78p. Disponível: $<$ www.deus.nsw.gov.au>. Acesso: setembro 2006.

NEW SOUTH WALES. Greywater Reuse in Sewered Single Domestic Premises, Austrália, 2000. 21p. Acesso: junho 2005.

NEW SOUTH WALES. Code of Practice Plumbing Drainage. Austrália, 2006. 169p. Disponível: <www.deus.nsw.gov.au>. Acesso: setembro 2006.

NEW SOUTH WALES $2006^{\mathrm{a}}$. Greywater and Sewage Recycling in Multi-Unit Dwellings and Commercial Premises - Interim Guidance. Disponível em:

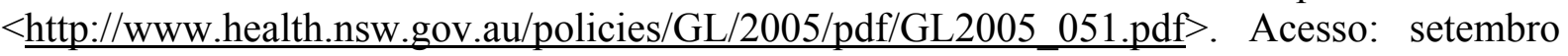
2006.

OLIVEIRA,L. Metodologia para a implantação de programa de uso racional da água em edifícios. 1999. Tese (doutorado). Escola Politécnica da Universidade de São Paulo, São Paulo, 1999.

PALADY, P. FMEA : análise dos modos de falha e efeitos : prevendo e prevenindo problemas antes que ocorram. 3 d. São Paulo, 2004. 269p.

PMI - PROJECT MANAGEMENT INSTIUTUTE. A Guide to the Project Management Body of Knowledge. Pensilvânia: Project Management Institute, Inc, 2004. 403p. 
PNCDA. Programa Nacional de Combate ao Desperdício da Água. 2006. Disponivel em: $<$ http: Www.pncda.gov.br>. Acesso junho. 2006.

ROSRUD, T. Sanitary Installations: Properties they ought to have. Performance requirements and quality testing of sanitary installations. In: INTERNATIONAL SYMPOSIUM ON WATER SUPPLY AND DRAINAGE FOR BUILDINGS.CIB-W62. SEMINAR, Oslo, 1980. Proceedings.

SCHEE, W. G. Experiences with collective domestic water system in Leidsche Rijn. In: INTERNATIONAL SYMPOSIUM ON WATER SUPPLY AND DRAINAGE FOR BUILDINGS. CIB W-62.SEMINAR, Paris, 2004.Proceedings... 5 p.

SANTOS,D. Contribuições para a estruturação de modelo aberto para o dimensionamento otimizado dos sistemas prediais de esgotos sanitários. Tese (doutorado). Escola Politécnica da Universidade de São Paulo, São Paulo, 1998.

SAUTCHUK,C. Formulação de diretrizes para implantação de programas de conservação de água em edificações. Dissertação (mestrado). Escola Politécnica da Universidade de São Paulo, São Paulo, 2004.

WASHINGTON STATE HEALTH DEPARTMENT. Cross-Connection Control for small Water Systems. Washington, 2004. 261p. Disponível em: $<$ http://www.doh.wa.gov/ehp/dw/Publications/CCC_Guidance_Document.htm $>$. Acesso: maio 2007.

WATER REGULATION ADVISORY SCHEME. Reclaimed water systems. Information about installing, modifying or maintaining reclaimed water systems. Reino Unido, 1999. 6p. Disponível em: <http://wras.co.uk/PDF_Files/IGN\%209-02-04\%20Reclaimed.pdf.> Acesso: março de 2006.

WORLD HEALth ORAGNIZATION. Health Aspects of Plumbing. Suíça, 2006. 139p. Disponível em: <http://whqlibdoc.who.int/publications/2006/9241563184_eng.pdf >. Acesso: abril 2007. 


\section{$\underline{\text { Vazão de projeto }}$}

O sistema será dimensionado baseado no uso simultâneo dos equipamentos, sendo utilizada a função distribuição binomial. A expressão para a determinação da quantidade de aparelhos utilizados simultaneamente é apresentada a seguir:

$m \geq n p+f c \sqrt{n p(1-p)}$

Onde:

m é o $n^{\circ}$ de aparelhos simultâneos;

n é o $n^{\circ}$ total de aparelhos;

p é a probabilidade do aparelho estar funcionando;

fc é o fator de confiabilidade ${ }^{7}$.

A Vazão de projeto está relacionada com o $\mathrm{n}^{\mathrm{o}}$ de equipamentos simultâneos e a vazão de contribuição de cada equipamento.

$Q=\sum m \cdot q$

Onde:

Q é a vazão no trecho considerado, em L/s;

q é a vazão unitária do aparelho sanitário, em L/s.

${ }^{7} \mathrm{O}$ fator confiabilidade esta relacionado com o fator de falha (GRAÇA, 1985 pag 235). 


\section{Velocidade Terminal}

Segundo Graça (1985) velocidade terminal é aquela que permanece constante a partir de um determinado momento no escoamento.

$V_{t}=13\left(\frac{Q_{t q}}{D_{t q}}\right)^{\frac{2}{5}}$

Onde:

$\mathrm{V}_{\mathrm{t}}$ é a velocidade terminal, em $\mathrm{m} / \mathrm{s}$;

$\mathrm{Q}_{\mathrm{tq}}$ é a vazão no tubo de queda, em $\mathrm{m}^{3} / \mathrm{s}$;

$D_{\text {tq }}$ é o diâmetro do tubo de queda, em m.

\section{$\underline{\text { Vazão de ar no tubo de queda }}$}

No interior do tubo de queda existe o esgoto mais o ar, devido ao prolongamento do tubo de queda e da existência dos ramais. Para determinar a pressão existente no interior do tubo de queda é necessário saber qual a vazão de ar nele existente.

$Q_{a r}=K \cdot Q^{2 / 5}-1,5 \cdot Q$

Onde:

Qar é a vazão de ar no interior do tubo de queda, em L/s;

K é um coeficiente adimensional, varia de acordo com o diâmetro da tubulação.

\section{Pressões no interior do tubo de queda}

$\Delta P_{\max }=K_{t q} \cdot Q_{a r}^{2}$

Sabe-se que: 


$$
K_{t q}=4,9 \times 10^{5}\left[\frac{1}{D_{t q}^{4}}\left(1+70 \frac{l s}{D_{t q}}+0,4 n_{c}\right)+2 \sum_{j=1, t=1}^{R, s} \frac{K_{j}}{\left(D_{t q}-2 e_{1}\right)^{4}}\right]
$$

Onde:

$\mathrm{D}_{\mathrm{tq}}$ é o diâmetro do tubo de queda, em mm;

$\mathrm{K}_{\mathrm{tq}}$ é o coeficiente de máxima perda de pressão de ar no tubo de queda;

$1_{\mathrm{s}}$ é o comprimento da parte seca do tubo de queda, em m;

$\mathrm{n}_{\mathrm{c}}$ é o $\mathrm{n}^{\mathrm{o}}$ de curvas da parte seca do tubo de queda;

$\mathrm{k}_{\mathrm{j}}$ são os coeficientes de perda de pressão do ramal considerado;

j é o índice representativo do ramal;

$\mathrm{e}_{1}$ é a espessura da coroa circular no trecho do tubo de queda entre o ramal j e o j+1;

$\mathrm{s}$ é o $\mathrm{n}^{\mathrm{o}}$ de trechos do tubo de queda respectivos ao $\mathrm{n}^{\mathrm{o}}$ total de ramais em uso simultâneo

\section{Cálculo dos Diâmetros das Tubulações}

\section{Para o tubo de queda}

$D_{t q}=\frac{0.166 n^{3 / 8} Q_{t q}^{3 / 8}}{t_{0}^{5 / 8}}$

Sendo:

$\mathrm{D}_{\mathrm{tq}} \mathrm{o}$ diâmetro do tubo de queda, em m;

$\mathrm{Q}_{\mathrm{tq}}$ a vazão de projeto no tubo de queda, em L/s;

n o coeficiente de Manning; 
$\mathrm{t}_{0}$ a taxa de ocupação de água durante o escoamento no tubo de queda, parâmetro adimensional.

$t_{0}=\frac{S_{e}}{S_{t q}}$

Sendo:

$\mathrm{S}_{\mathrm{e}}$ a área de seção transversal do círculo por onde ocorre o fluxo de ar no tubo de queda;

$\mathrm{S}_{\mathrm{tq}}$ a área da seção transversal do tubo de queda.

Fernandes (2002) afirma que para garantir o escoamento anular no interior do tubo de queda, $\mathrm{t}_{0}$ deve estar situado entre $1 / 4$ e $1 / 3$, de maneira que o escoamento não preencha completamente a seção.

\section{$\underline{\text { Ramais de esgoto, Ramais de descarga, Subcoletores e Coletores prediais }}$}

Fernandes (2002) afirma que o taxa de ocupação deve ser $1 / 2$ ou $3 / 4$ da seção, para garantir o escoamento em conduto livre.

$$
\begin{aligned}
& D_{T_{1 / 2}}=\frac{n^{3 / 8} Q_{e}^{3 / 8} I^{-3 / 16}}{6,644} \\
& D_{T_{3 / 4}}=\frac{n^{3 / 8} Q_{e}^{3 / 8} I^{-3 / 16}}{8,32}
\end{aligned}
$$

Sendo:

$\mathrm{D}_{\mathrm{T}^{1 / 2}}$ o diâmetro do trecho considerado com escoamento a $1 / 2$ seção, em m;

$\mathrm{D}_{\mathrm{T} 3 / 4} \mathrm{O}$ diâmetro do trecho considerado com escoamento a 3/4 seção, em m;

n é o coeficiente de maning, em $s / \sqrt[3]{m}$; 
$\mathrm{Q}_{\mathrm{e}}$ é a vazão no trecho considerado, em L/s;

I é a declividade do trecho considerado, em $\mathrm{m} / \mathrm{m}$.

Segundo Santos (1998), a declividade pode ser testada quanto as condições de arraste do material sólido através do principio da tensão trativa, na qual considera-se o escoamento em regime permanente.

$T_{r}=\gamma \cdot R H \cdot I \geq 1,0 P_{a}$

Sendo:

$\mathrm{T}_{\mathrm{r}}$ é a tensão trativa, em $\mathrm{Pa}$;

RH é o raio hidráulico, em m;

$\gamma_{\mathrm{e}}$ é o peso específico do esgoto, em $\mathrm{N} / \mathrm{m}^{2}$.

\section{Depressão máxima resultante (Dr)}

$D_{r}=\operatorname{Max}\left[D_{r, s i} ; D_{r, t v} ;\right]+\mid 1\left[D_{r, a m b}\right]$

Sendo:

Dr,si a depressão resultante do efeito de sifonagem induzida

Dr,tv a depressão resultante dos efeitos de tiragem térmica e ação do vento (Pascal)

Dr,amb a depressão resultante das variações de pressão ambiental (Pascal)

| 1 = 0 ambientes em pressão negativa (exaustão)

| 1 = 1 ambientes em pressão positiva (ventilação ou ar condicionado) 


\section{Depressão resultante do efeito de sifonagem induzida (Dr, si)}

$\operatorname{Dr}, \mathrm{si}=K_{t q} \cdot Q^{2}$ ar

Sendo:

$\mathrm{K}_{\mathrm{tq}}$ o coeficiente de máxima perda de pressão do ar no tubo de queda;

$Q_{a r}$ é a vazão de ar que escoa pelo núcleo do tubo de queda, em L/s.

$Q_{a r}=\alpha \cdot Q_{t q}^{2 / 5}-1.5 Q_{t q}$

Sendo:

$\mathrm{Q}_{\mathrm{tq}}$ é a vazão no tubo de queda em L/s;

$\alpha$ é um coeficiente adimensional.

Depressão resultante do efeito tiragem térmica e ação do vento (Dr, tv)

$$
\operatorname{Dr}, t v=176,77\left(-19,62 h_{T q} \cdot \frac{\Delta \theta_{i}}{\Delta \theta_{i} \theta_{e}}+\varepsilon \frac{V_{e}{ }^{2}}{\theta_{e}{ }^{2}}\right)
$$

Onde:

$\mathrm{h}_{\mathrm{tq}}$ é a altura do tubo de queda, em m;

$\theta_{\mathrm{i}}$ é a temperatura do ar no interior do tubo de queda, em k;

$\theta_{\mathrm{e}}$ é a temperatura do ar exterior, em k;

$\Delta \theta_{\mathrm{i}}$ é a diferença de temperatura do ar no interior do tubo de queda e a exterior, em k;

$\mathrm{V}_{\mathrm{e}}$ é a velocidade do vento, em $\mathrm{m} / \mathrm{s}$;

$\varepsilon$ é o coeficiente de pressão dinâmica do terminal do tubo de queda, adimensional. 


\section{Depressão resultante das variações da pressão ambiental (Dr, amb)}

O valor de Dr, amb é desprezível em condições normais.

Após o calculo das variáveis acima, deve-se utilizar o modelo proposto por Santos pra determinar se é necessário existir a ventilação secundária.

\section{Sistema de Ventilação Secundária Segundo a NBR 8160}

$D_{C V}=C \cdot f^{0,2}$

$C=4,06\left[L_{V}\left(Q_{a r}\right)^{2}\right]^{1 / 5}$

Onde:

$\mathrm{D}_{\mathrm{cv}}$ é o diâmetro da coluna de ventilação, em mm;

f é o coeficiente de perda de carga distribuída, adimensional;

$\mathrm{L}_{\mathrm{v}}$ é comprimento da tubulação, em mm. 


\section{DIMENSIONAMENTO PELO MÉTODO HIDRÁULICO}

24 pavimentos

4 chuveiros e 4 lavatórios conectado em único tubo de queda

\begin{tabular}{|c|c|c|c|c|c|}
\hline Equipamento sanitário & Vazão & $\mathrm{T}(\mathrm{s})^{*}$ & $(\mathrm{~s})^{*}$ & $\mathrm{p}$ & $\mathrm{fc}$ \\
\hline lavatório & 0,15 & 600 & 24 & 0,04 & 2,326 \\
\hline chuveiro & 0,2 & 2700 & $\# \#$ & 0,1722 & 2,326 \\
\hline
\end{tabular}

* intervalo de tempo médio de descargas

\begin{tabular}{|c|c|}
\hline $\mathrm{n}$ & $\mathrm{Qp}(1 / \mathrm{s})$ \\
\hline 9 & 1,35 \\
\hline 26 & 5,2 \\
\hline
\end{tabular}

** duração média das descargas

Vazão de projeto $=6,55 \mathrm{l} / \mathrm{s}$

\section{CALCULO B}

\begin{tabular}{|ccc|} 
Trecho do TQ & Vazoes $\mathbf{L} / \mathbf{s}$ & $\mathbf{Q ~ e t , j}$ \\
1 & 0,35 & 0,35 \\
2 & 0,35 & 0,7 \\
3 & 0,35 & 1,05 \\
4 & 0,35 & 1,4 \\
5 & 0,35 & 1,75 \\
6 & 0,35 & 2,1 \\
7 & 0,35 & 2,45 \\
8 & 0,35 & 2,8 \\
9 & 0,35 & 3,15 \\
10 & 0,2 & 3,35 \\
11 & 0,2 & 3,55 \\
12 & 0,2 & 3,75 \\
13 & 0,2 & 3,95 \\
\hline
\end{tabular}

\begin{tabular}{|c|}
\hline D $75 \mathrm{~mm}$ \\
75 \\
75 \\
75 \\
75 \\
75 \\
75 \\
75 \\
75 \\
75 \\
75 \\
75 \\
75 \\
75
\end{tabular}

\begin{tabular}{|c|c|c|}
\hline $\mathbf{1 0 0} \mathbf{m m}$ & et $\mathbf{7 5 m m}$ & et $\mathbf{1 0 0} \mathbf{m m}$ \\
\hline 100 & $9,98 \mathrm{E}-01$ & $8,40 \mathrm{E}-01$ \\
100 & $1,51 \mathrm{E}+00$ & $1,27 \mathrm{E}+00$ \\
100 & $1,93 \mathrm{E}+00$ & $1,62 \mathrm{E}+00$ \\
100 & $2,29 \mathrm{E}+00$ & $1,93 \mathrm{E}+00$ \\
100 & $2,62 \mathrm{E}+00$ & $2,21 \mathrm{E}+00$ \\
100 & $2,93 \mathrm{E}+00$ & $2,46 \mathrm{E}+00$ \\
100 & $3,21 \mathrm{E}+00$ & $2,70 \mathrm{E}+00$ \\
100 & $3,48 \mathrm{E}+00$ & $2,93 \mathrm{E}+00$ \\
100 & $3,73 \mathrm{E}+00$ & $3,14 \mathrm{E}+00$ \\
100 & $3,87 \mathrm{E}+00$ & $3,26 \mathrm{E}+00$ \\
100 & $4,01 \mathrm{E}+00$ & $3,37 \mathrm{E}+00$ \\
100 & $4,14 \mathrm{E}+00$ & $3,49 \mathrm{E}+00$ \\
100 & $3,87 \mathrm{E}+00$ & $3,26 \mathrm{E}+00$
\end{tabular}

$\begin{array}{ccc}\text { Kj } & \text { ls } & \text { nc } \\ 9 & 6 & 1 \\ 9 & 6 & 1 \\ 9 & 6 & 1 \\ 9 & 6 & 1 \\ 9 & 6 & 1 \\ 9 & 6 & 1 \\ 9 & 6 & 1 \\ 9 & 6 & 1 \\ 9 & 6 & 1 \\ 9 & 6 & 1 \\ 9 & 6 & 1 \\ 9 & 6 & 1 \\ 9 & 6 & 1\end{array}$

$\begin{array}{cc} & \text { B1 } \\ 28402938 & 3,17 \mathrm{E}-07 \\ 26833779 & 3,35 \mathrm{E}-07 \\ 25611943 & 3,51 \mathrm{E}-07 \\ 24580471 & 3,66 \mathrm{E}-07 \\ 23675447 & 3,80 \mathrm{E}-07 \\ 22862929 & 3,94 \mathrm{E}-07 \\ 22122192 & 4,07 \mathrm{E}-07 \\ 21439424 & 4,20 \mathrm{E}-07 \\ 20804838 & 4,33 \mathrm{E}-07 \\ 20460985 & 4,40 \mathrm{E}-07 \\ 20129381 & 4,47 \mathrm{E}-07 \\ 19809085 & 4,54 \mathrm{E}-07 \\ 20460985 & 4,40 \mathrm{E}-07\end{array}$

9,631E-08 9,978E-08 $1,027 \mathrm{E}-07$ 1,054E-07 $1,078 \mathrm{E}-07$ 1,101E-07 1,124E-07 1,145E-07 $1,167 \mathrm{E}-07$ $1,178 \mathrm{E}-07$ $1,19 \mathrm{E}-07$ 1,202E-07 1,178E-07 

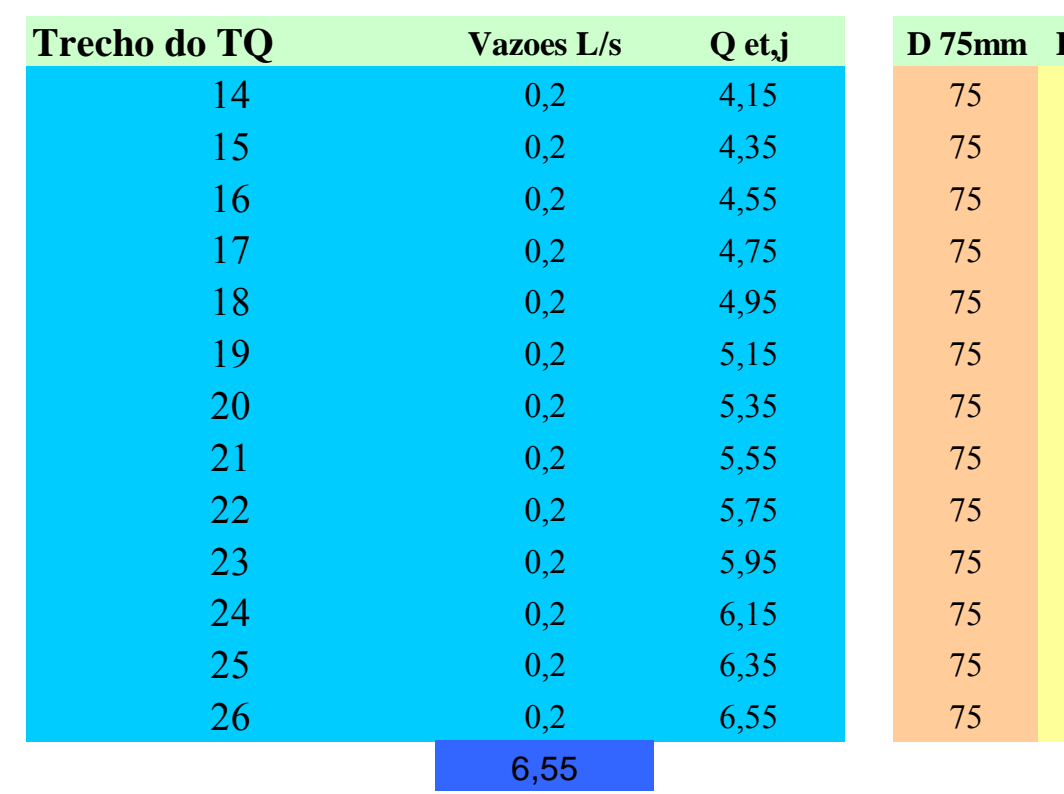

\begin{tabular}{|c|r|r}
\hline $\mathbf{1 0 0} \mathbf{m m}$ & et $\mathbf{7 5 m m}$ & et $\mathbf{1 0 0 \mathbf { m m }}$ \\
\hline 100 & $4,01 \mathrm{E}+00$ & $3,37 \mathrm{E}+00$ \\
100 & $4,14 \mathrm{E}+00$ & $3,49 \mathrm{E}+00$ \\
100 & $4,27 \mathrm{E}+00$ & $3,60 \mathrm{E}+00$ \\
100 & $4,40 \mathrm{E}+00$ & $3,70 \mathrm{E}+00$ \\
100 & $4,53 \mathrm{E}+00$ & $3,81 \mathrm{E}+00$ \\
100 & $4,65 \mathrm{E}+00$ & $3,92 \mathrm{E}+00$ \\
100 & $4,77 \mathrm{E}+00$ & $4,02 \mathrm{E}+00$ \\
100 & $4,89 \mathrm{E}+00$ & $4,12 \mathrm{E}+00$ \\
100 & $5,01 \mathrm{E}+00$ & $4,22 \mathrm{E}+00$ \\
100 & $5,13 \mathrm{E}+00$ & $4,31 \mathrm{E}+00$ \\
100 & $5,24 \mathrm{E}+00$ & $4,41 \mathrm{E}+00$ \\
100 & $5,35 \mathrm{E}+00$ & $4,51 \mathrm{E}+00$ \\
100 & $5,47 \mathrm{E}+00$ & $4,60 \mathrm{E}+00$ \\
& & \\
\hline
\end{tabular}

7

\begin{tabular}{|c|c|c|c|c|c|}
\hline $\mathbf{K j}$ & ls & nc & & B1 & B2 \\
\hline 9 & 6 & 1 & 20129381 & $4,47 \mathrm{E}-07$ & $1,19 \mathrm{E}-07$ \\
\hline 9 & 6 & 1 & 19809085 & $4,54 \mathrm{E}-07$ & $1,202 \mathrm{E}-07$ \\
\hline 9 & 6 & 1 & 19499269 & $4,62 \mathrm{E}-07$ & $1,213 \mathrm{E}-07$ \\
\hline 9 & 6 & 1 & 19199208 & $4,69 \mathrm{E}-07$ & $1,225 \mathrm{E}-07$ \\
\hline 9 & 6 & 1 & 18908257 & $4,76 \mathrm{E}-07$ & $1,236 \mathrm{E}-07$ \\
\hline 9 & 6 & 1 & 18625839 & $4,83 \mathrm{E}-07$ & $1,247 \mathrm{E}-07$ \\
\hline 9 & 6 & 1 & 18351438 & $4,90 \mathrm{E}-07$ & $1,258 \mathrm{E}-07$ \\
\hline 9 & 6 & 1 & 18084589 & 4,98E-07 & $1,269 \mathrm{E}-07$ \\
\hline 9 & 6 & 1 & 17824870 & $5,05 \mathrm{E}-07$ & $1,28 \mathrm{E}-07$ \\
\hline 9 & 6 & 1 & 17571899 & $5,12 \mathrm{E}-07$ & $1,291 \mathrm{E}-07$ \\
\hline 9 & 6 & 1 & 17325326 & $5,19 \mathrm{E}-07$ & $1,302 \mathrm{E}-07$ \\
\hline 9 & 6 & 1 & 17084831 & $5,27 \mathrm{E}-07$ & $1,313 \mathrm{E}-07$ \\
\hline \multirow[t]{3}{*}{9} & 6 & 1 & 16850121 & $5,34 \mathrm{E}-07$ & $1,324 \mathrm{E}-07$ \\
\hline & & & $5,4 \mathrm{E}+08$ & $1,2 \mathrm{E}-05$ & $3,08 \mathrm{E}-06$ \\
\hline & \multicolumn{3}{|c|}{$2 \times B$} & 2,3E-05 & $6,15 \mathrm{E}-06$ \\
\hline
\end{tabular}

\begin{tabular}{|cc|}
\hline CALCULO A & Dtq \\
A1 & 75 \\
A2 & 100 \\
\hline CALCULO Ktq & $\mathbf{4 9 0 . 0 0 0 * ( A + B )}$ \\
\hline Ktq1 & 11,4376805 \\
\hline ktq2 & 3,04155858 \\
\hline
\end{tabular}

\section{Qar=alfa.Qtq^2/5 -1,5Qtq}

22,62

41,71

75

100

\begin{tabular}{|cc|}
\hline Drs, I (Pa) & $\mathrm{D}(\mathrm{mm})$ \\
\hline 5853,81 & 75 \\
5291,49 & 100
\end{tabular}

A 2,212E-07

\begin{tabular}{|cc|}
\hline D & ALFA \\
\hline 50 & 8 \\
75 & 15,3 \\
100 & 24,3 \\
150 & 46,5 \\
\hline
\end{tabular}




\section{DIMENSIONAMENTO}

$\begin{array}{lccc}\text { TIPOS DE SIFOES } & \text { H0i }(\mathbf{m m}) & \text { Coef evap } & \text { Rv,i } \\ \text { GARRAFA } & 37 & 1,73 & 1,72 \\ \text { CAIXA SIFONADA } 100 \mathrm{~mm} & 50 & 5 & 1 \\ \text { CAIXA SIFONADA } 150 \mathrm{~mm} & 47 & 5,5 & 0,07\end{array}$

$\mathrm{Ha}, \mathrm{i}=\mathrm{H} 0, \mathrm{i}-\mathrm{h}$ e,i

EVAPORAÇÃO 15,795

PERDA DE ALTURA HIDRICA ADMISSIVEL CALCULO Ha,i

CAIXA SIFONADA 100mm 34,205

DEPRESSÃO ADMISSIVEL NO SISTEMA

CALCULO Hs,i

CAIXA SIFONADA $100 \mathrm{~mm}$

SE Ha, i $<$ Hs,i

CAIXA SIFONADA $100 \mathrm{~mm}$

SE Há,i > Hs,i

CAIXA SIFONADA 100mm
25,0155

Da,i

671,1021

$\mathrm{Da}, \mathrm{i}$

490,8041 
DIMENSIONAMENTO DA SOBREPRESSAO

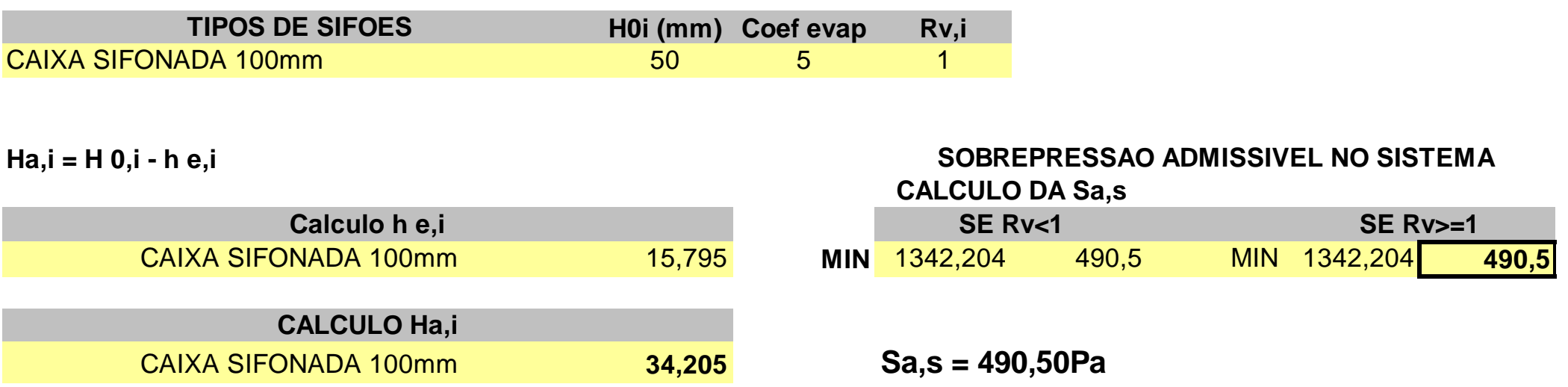

DEPRESSÃO ADMISSIVEL NO SISTEMA

\section{CALCULO Hs,}

CAIXA SIFONADA 100mm

SE Ha, i < Hs,i

CAIXA SIFONADA $100 \mathrm{~mm}$

SE Há,i > Hs,i

CAIXA SIFONADA $100 \mathrm{~mm}$

$\mathrm{Da}, \mathrm{i}$

490,8041

Resultado:

A depressão admissivel no sistema é 490,5 Pa 
RESULTADOS DA ANALISE DA SUFICIENCIA DA VENTILAÇÃO PRIMÁRIA

\begin{tabular}{lc} 
DEPRESSÃO MAXIMA ADMISSIVEL (Pa) & 310,97 \\
DEPRESSÃO NO TQ 75MM & 5853,81 É PRECISO VENTILAR \\
DEPRESSÃO NO TQ 100MM & 5291,49 É PRECISO VENTILAR \\
\hline
\end{tabular}


ANEXO 03 - DIMENSIONAMENTO DO SISTEMA DE DISTRIBUIÇÃO

O método do dimensionamento do sistema de distribuição será baseado no modelo proposto por Gonçalves (1986). No modelo existe uma série de equações que fica mais fácil de manuseá-las com a ajuda de computadores, para isso será utilizado um programa desenvolvido por Correia 2003.

Para utilizar o modelo é necessário seguir uma série de passos:

- Identificar os ambientes sanitários existentes;

- Definir o traçado geométrico do sistema de distribuição, identificando os ambientes sanitários atendidos pelas tubulações;

- Definir o período de pico (em segundos);

- Definir a área de influencia $\left(\mathrm{m}^{2}\right)$ de cada ambiente sanitário;

- Definir as densidades populacionais, no período de pico, nas áreas de influencia- $\mathrm{d}_{\min }$, $\mathrm{d}_{\text {prov }}$ e $\mathrm{d}_{\max }$.

- Definir o $\mathrm{n}^{\mathrm{o}}$ total de aparelhos sanitários de cada tipo, em cada ambiente sanitário.

- Definir para cada tipo de aparelho sanitário, atendendo às áreas de influencia os seguintes parâmetros:

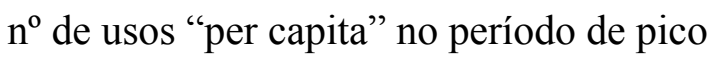

- $\mu_{\min (\mathrm{i})}$ - usos "per capita" mínimo (usos/pessoa);

- $\mu_{\text {prov (i) }}$ - usos "per capita" mais provável (usos/pessoa);

- $\mu_{\max (i)}$ - usos “per capita” máximo (usos/pessoa).

Vazão unitária do aparelho sanitário, a saber:

- $\mathrm{q}_{\min (\mathrm{i})}$ - vazão unitária mínima (1/s);

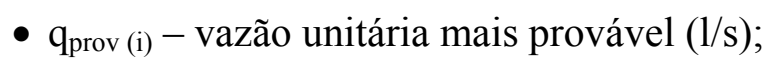

- $\mathrm{q}_{\max (\mathrm{i})}$ - vazão unitária máxima (1/s). 
Duração da descarga de um aparelho sanitário, a saber:

- $\mathrm{t}_{\min (\mathrm{i})}$ - duração mínima da descarga (s);

- $\mathrm{t}_{\text {prov (i) }}$ - duração mais provável da descarga (s);

- $\mathrm{t}_{\max (\mathrm{i})}$ - duração máxima da descarga (s);

Definir os fatores de falha admissíveis, compatíveis com o nível de desempenho desejado para o sistema, a saber:

- $\varepsilon_{0}$ - fator de falha global;

- $\varepsilon_{\mathrm{L} \max }-$ fator de falha local máximo;

Calcular as médias e variâncias das variáveis aleatórias d (densidade populacional) e u (usos "per capita"):

$$
\begin{aligned}
& \mu_{d}=\frac{d_{\text {min }}+3 d_{\text {prov }}+d_{\text {max }}}{5} \\
& \sigma_{d}^{2}=\frac{\left(d_{\text {max }}-d_{\text {min }}\right)^{2}}{25} \\
& \mu_{u(i)}=\frac{\mu_{\min (i)}+3 \mu_{p r o v(i)}+\mu_{\max (i)}}{5} \\
& \sigma_{u(i)}^{2}=\frac{\left(\mu_{\max (i)}-\mu_{\text {min }(i)}\right)^{2}}{25}
\end{aligned}
$$

Calcular as médias e variâncias dos parâmetros de entrada, para a aplicação do modelo, a saber:

- Intervalo entre descargas consecutivas (T-s):

$$
\mu_{t(i)}=\frac{t_{p} \cdot n_{1}}{A}\left(\frac{1}{\mu_{u(i)}}+\frac{\sigma_{u(i)}^{2}}{\mu_{u(i)}}\right) \cdot\left(\frac{1}{\mu_{d}}+\frac{\sigma_{d}^{2}}{\mu_{d}^{3}}\right)
$$


$\sigma_{T(i)}^{2}=\left(\frac{t_{p} \cdot n_{1}}{A}\right)^{2}\left[\left(\frac{1}{\mu_{u(i)}}+\frac{\sigma_{u(i)}^{2}}{\mu_{u(i)}^{3}}\right)^{2} \frac{\sigma_{d}^{2}}{\mu_{d}^{4}}+\left(\frac{1}{\mu_{d}}+\frac{\sigma_{d}^{2}}{\mu_{d}^{3}}\right)^{2} \cdot \frac{\sigma_{u(i)}^{2}}{\mu_{u(i)}^{4}}+\frac{\sigma_{u(i)}^{2} \cdot \sigma_{d}^{2}}{\mu_{u(i)}^{4} \mu_{d}^{4}}\right]$

- Duração da descarga de um aparelho (t-s):

$$
\begin{aligned}
\mu_{t(i)} & =\frac{t_{\min (i)}+3 t_{p r o v(i)}+t_{\max (i)}}{5} \\
\sigma_{t(i)}^{2} & =\frac{\left(t_{\max (i)}-t_{\min (i)}\right)^{2}}{25}
\end{aligned}
$$

- Vazão unitária dos aparelhos sanitários $(\mathrm{q}-1 / \mathrm{s})$ :

$$
\begin{aligned}
\mu_{q(i)} & =\frac{q_{\min (i)}+3 q_{p r o v(i)}+q_{\max (i)}}{5} \\
\sigma_{q(i)}^{2} & =\frac{\left(q_{\max (i)}-q_{\min (i)}\right)^{2}}{25}
\end{aligned}
$$

- Calcular as médias e variâncias das variáveis aleatórias $\mathrm{p}_{1}$ e os parâmetros $\mathrm{a}_{1}$ e $\mathrm{b}_{1}$ das distribuições de probabilidades Beta-Binomial:

$$
\begin{aligned}
& \mu_{p(i)}=\frac{\mu_{t(i)}}{\mu_{T(i)}}+\frac{\mu_{t(i)}}{\mu_{T(i)}^{3}} \sigma_{T(i)}^{2}-\frac{\sigma_{t(i)}^{2}}{\mu_{T(i)}^{2}} \\
& \sigma_{p(i)}^{2}=\left(\frac{\mu_{t(i)}}{\mu_{T(i)}}\right)^{2} \cdot\left(\frac{\sigma_{t(i)}^{2}}{\mu_{T(i)}^{2}}+\frac{\sigma_{T(i)}^{2}}{\mu_{T(i)}^{2}}-2 \frac{\sigma_{t(i)}^{2}}{\mu_{t(i)} \mu_{T(i)}}\right) \\
& a_{(i)}=\frac{\mu_{p(i)}^{2}}{\sigma_{p(i)}^{2}}-\frac{\mu_{p(i)}^{3}}{\sigma_{p(i)}^{2}}-\mu_{p(i)} \\
& b_{(i)}=\frac{1-\mu_{p(i)}}{\mu_{p(i)}} \cdot a_{(i)}
\end{aligned}
$$


- Definir o $\mathrm{n}^{\mathrm{o}}$ de aparelhos de cada tipo, atendidos pelo trecho de tubulação considerado n(i); cabe comentar que um tipo de aparelho, para efeito de aplicação do modelo, é definido pelo conjunto de valores das médias e variâncias das variáveis $\mathrm{T}, \mathrm{t}$ e q, isto é, qualquer alteração em algum dos caracteriza um outro "tipo" de aparelho sanitário, para efeito da determinação da vazão de projeto $Q_{p}$.

Calcular as médias e variâncias das vazões geradas no trecho, pelos diferentes tipos de aparelhos sanitários:

$$
\begin{gathered}
\mu_{q}=\sum_{i} \mu_{q(i)} \\
\sigma_{Q}^{2}=\sum_{i} \sigma_{Q(i)}^{2}
\end{gathered}
$$

- Calcular a probabilidade $\mathrm{p}_{0}$, no trecho considerado:

$$
p_{0}=\pi_{i} p_{0(i)}
$$

- Calcular a média e variância da vazão $\mathrm{Q} / \mathrm{Q} \neq 0$, no trecho considerado:

$$
\begin{aligned}
& \mu_{Q / Q \neq 0}=\frac{\mu_{Q}}{1-p_{0}} \\
& \sigma_{Q / Q \neq 0}^{2}=\frac{\sigma_{Q}^{2}}{1-p_{0}}-\frac{p_{0}}{\left(1-p_{0}\right)^{2}} \mu_{Q}^{2}
\end{aligned}
$$

- Calcular o fator de falha local $\varepsilon_{\mathrm{L}}$ :

Se $0 \leq p_{0} \leq 1-\frac{\varepsilon_{0}}{\varepsilon_{L \max }} \longrightarrow \varepsilon_{L}=\frac{\varepsilon_{G}}{1-p_{0}}$

Se $1-\frac{\varepsilon_{G}}{\varepsilon_{L \max }}<p_{0} \leq 1 \longrightarrow \varepsilon_{L}=\varepsilon_{L \max }$ 
- Calcular os parâmetros da distribuição de probabilidades Gama, da variável aleatória $\mathrm{Q} / \mathrm{Q} \neq 0$ :

$$
\begin{aligned}
& r_{Q}=\frac{\mu_{Q / Q \neq 0}^{2}}{\sigma_{Q / Q \neq 0}^{2}} \\
& \lambda_{Q}=\frac{\mu_{Q / Q \neq 0}}{\sigma_{Q / Q \neq 0}^{2}}
\end{aligned}
$$

- Calcular z:

Para $0,5<r_{Q}<12$ e $\varepsilon_{L}<0,5$ :

$$
Z=y-\frac{\mu_{Q / Q \neq 0}}{\sigma_{Q / Q \neq 0}}
$$

Sendo:

$$
y=A_{0}+A_{1} \ln \varepsilon_{L}+A_{2} \varepsilon_{L}^{2}+A_{3} \varepsilon_{L} \ln \varepsilon_{L}
$$

Onde:

$$
\begin{aligned}
& A_{0}=0,0106179-0,015684 r_{Q}^{2}+1,66011 \ln r_{Q}-0,0365992 \ln ^{2} r_{Q}+0,145241 r_{Q} \ln r_{Q} \\
& A_{1}=-0,998223-0,00231704 r_{Q}^{2}+0,357714 \ln r_{Q}-0,106577 \ln ^{2} r_{Q}+0,0201662 r_{Q} \ln r_{Q} \\
& A_{2}=-1,48338-0,000741918 r_{Q}^{2}+\frac{1,46426}{r_{Q}}-0,206282 \ln r_{Q} \\
& A_{3}=2,76031-2,72033 r_{Q}-0,0544844 r_{Q}^{2}+3,13504 \ln r_{Q}+1,04581 r_{Q} \ln r_{Q}
\end{aligned}
$$

Para:

$$
r_{Q} \geq 12 \longrightarrow z=0,329618-1,32066 \varepsilon_{L}-0,507301 \ln \varepsilon_{L}-0,0154816 \ln ^{2} \varepsilon_{L}
$$

- Calcular a vazão de projeto $\mathrm{Q}_{\mathrm{p}}$ :

$$
Q_{p}=\mu_{Q / Q \neq 0}+z \sigma_{Q / Q \neq 0}
$$

